\title{
WestVirginiaUniversity
}

THE RESEARCH REPOSITORY @ WVU

Graduate Theses, Dissertations, and Problem Reports

1999

\section{Causes and consequences of the 1909-1910 steel strike in the Wheeling District}

Louis Charles Martin

West Virginia University

Follow this and additional works at: https://researchrepository.wvu.edu/etd

\section{Recommended Citation}

Martin, Louis Charles, "Causes and consequences of the 1909--1910 steel strike in the Wheeling District" (1999). Graduate Theses, Dissertations, and Problem Reports. 824.

https://researchrepository.wvu.edu/etd/824

This Thesis is protected by copyright and/or related rights. It has been brought to you by the The Research Repository @ WVU with permission from the rights-holder(s). You are free to use this Thesis in any way that is permitted by the copyright and related rights legislation that applies to your use. For other uses you must obtain permission from the rights-holder(s) directly, unless additional rights are indicated by a Creative Commons license in the record and/ or on the work itself. This Thesis has been accepted for inclusion in WVU Graduate Theses, Dissertations, and Problem Reports collection by an authorized administrator of The Research Repository @ WVU. For more information, please contact researchrepository@mail.wvu.edu. 
Causes and Consequences of the 1909-1910 Steel Strike in the Wheeling District

\author{
Louis C. Martin
}

\author{
Thesis submitted to the \\ Eberly College of Arts and Sciences \\ at West Virginia University \\ in partial fulfillment of the requirements \\ for the degree of \\ Master of Arts \\ in \\ History
}

\author{
Ronald Lewis, Ph.D., Chair \\ Elizabeth Fones-Wolf, Ph.D. \\ Michal McMahon, Ph.D. \\ Department of History
}

Morgantown, West Virginia

1999

steelworkers, U. S. Steel, LaBelle, tin plate, Amalgamated Association of Iron, Steel and Tin Workers, Martins Ferry, West Virginia, Ohio

Copyright 1999 Louis C. Martin 


\begin{abstract}
Causes and Consequences of the 1909-1910 Steel Strike in the Wheeling District Louis C. Martin

This thesis is a study of the failure of trade unionism in the Wheeling District mills in the early twentieth century, a district whose unions had previously enjoyed great success. The conversion to tin plate in the district was, at first, beneficial to the skilled workers in the union, but with the combination of companies culminating in the creation of the United States Steel Corporation, the union could no longer count on the skill of its members for survival.

Ultimately, Wheeling steelworkers were victims of the modernization of the steel industry and a union that would not adopt industrial unionism to maintain its position in the new corporate
\end{abstract} environment. 


\section{Acknowlegments}

I would like to thank my parents and stepparents: Jeanne and William Barrett, and Louis and Kathleen Martin. Without their moral and financial support my higher education would not have been possible. I would also like to thank Becky Bailey for her help in teaching me how to research. If it were not for her I would still be wandering around the stacks, aimlessly reading books. My greatest debt is to the members of my committee. Elizabeth Fones-Wolf has helped my understanding of American history probably more than anyone has. Her teaching is clear, concise, and firmly rooted in reality, yet it guided me to the most complex issues of the subject. Ronald Lewis has served as my model of a researcher and a writer. He was always available to counsel me, encourage me, and make sense out of my rambling research and chaotic thoughts. Lastly, I would like to thank Michal McMahon. Without his encouragement and advice, I might never have entered the master's degree program. Furthermore, he has shaped my values and thinking, through the classes I have had with him and the discussions we have had in his office, more than any other teacher has. 


\section{Table of Contents}

Page Number

Abstract

Acknowledgments

Table of Contents

iv

List of Figures

$\mathrm{V}$

$\begin{array}{ll}\text { Introduction } & 1\end{array}$

Chapter 1

Rise of the Tin Plate Industry in the Wheeling District

Chapter 2

The Decline of the Amalgamated Association of Iron, Steel, and Tin Workers

Chapter 3

The 1909-1910 Strike

\section{Chapter 4}

Trying to Change the Union; Too Little, Too Late

3

Epilogue

Conclusion

Endnotes 


\section{List of Figures}

Preparing tin plate for the annealing furnace vi

Cartoon from the 1901 strike vii

Cartoon from Wheeling Intelligencer during 1909-1910 strike vii

Two crews of tin plate rollers $\quad$ viii

Ohio state militia occupying the Laughlin mill viii

Officers of the Amalgamated Association of Iron, Steel, and Tin Workers, 1909 ix

Map of Mill Towns in the Wheeling District $\quad x$ 


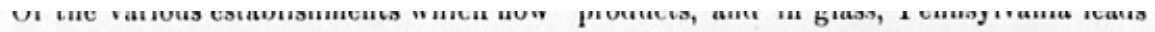

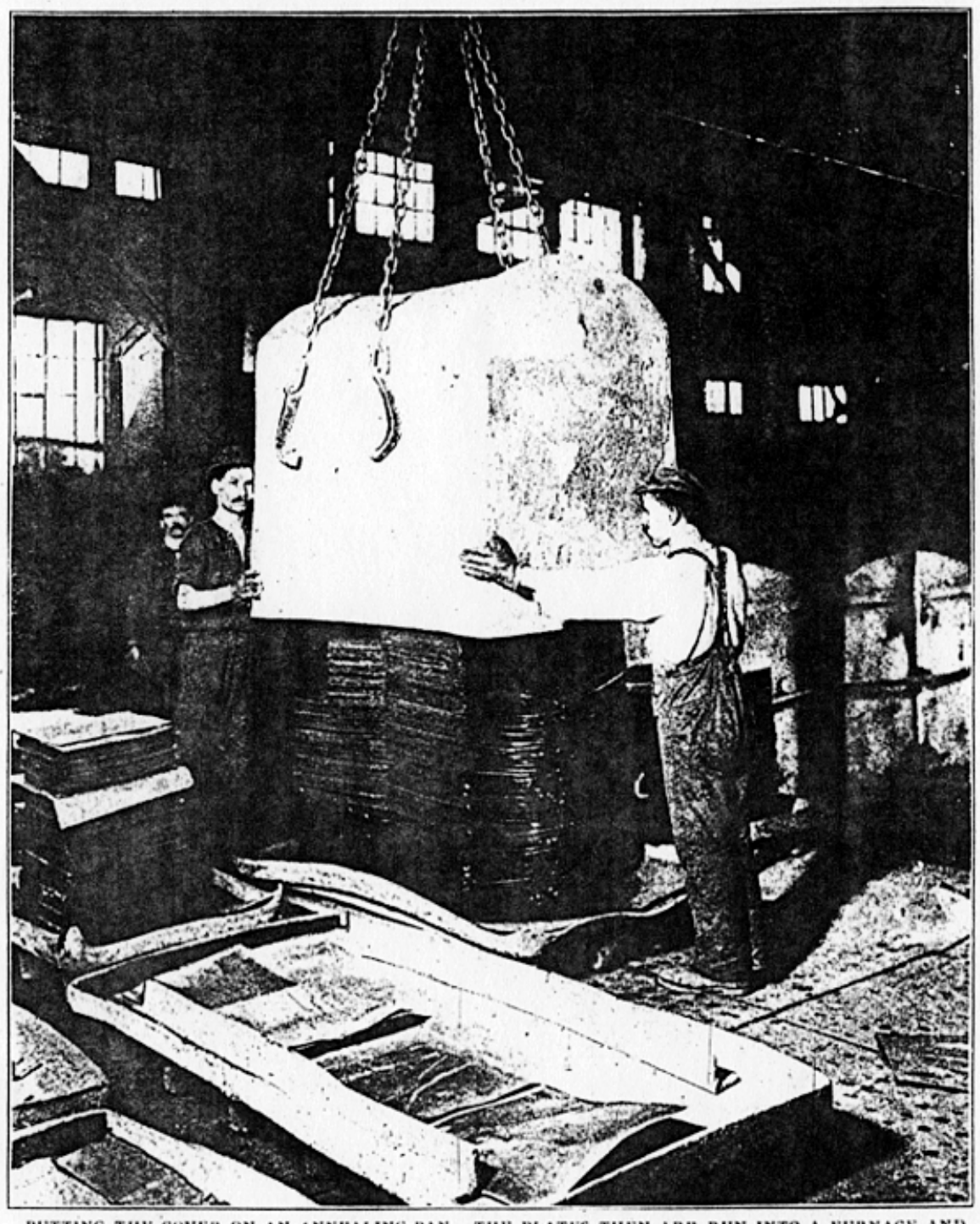

PUTTING THX COVRR ON AN ANNBALING-PAN, THR PLATKS TIIBN ARK RUN INTO A YURNACE AND

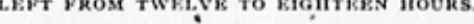

manufacture tin or terne nlates. or both. all the states in its tin industry. Ohio 


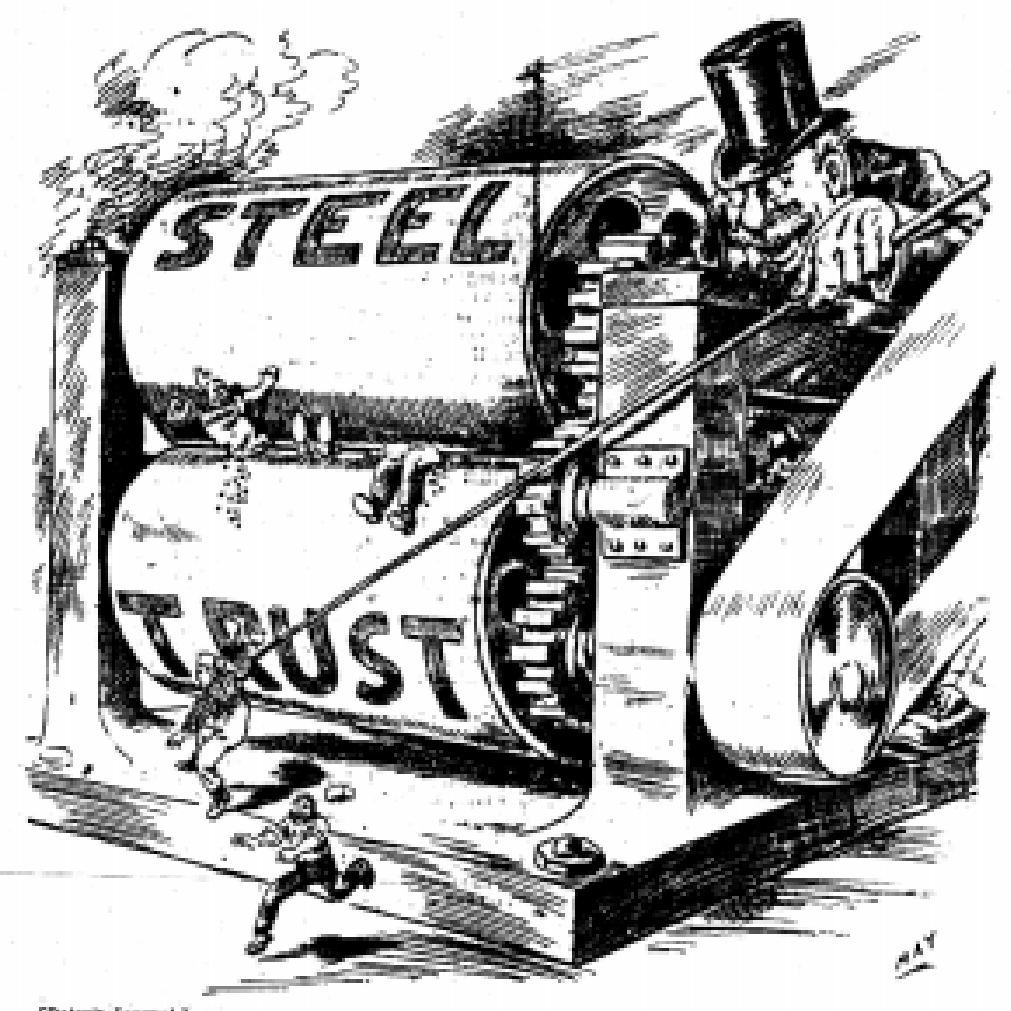

[Dutnar Jeemal.]

McMURTRY TESTING THE STEEL TRUSTS SHEET ROLLS.

\section{HE HAS IT ON HIS MIND!}

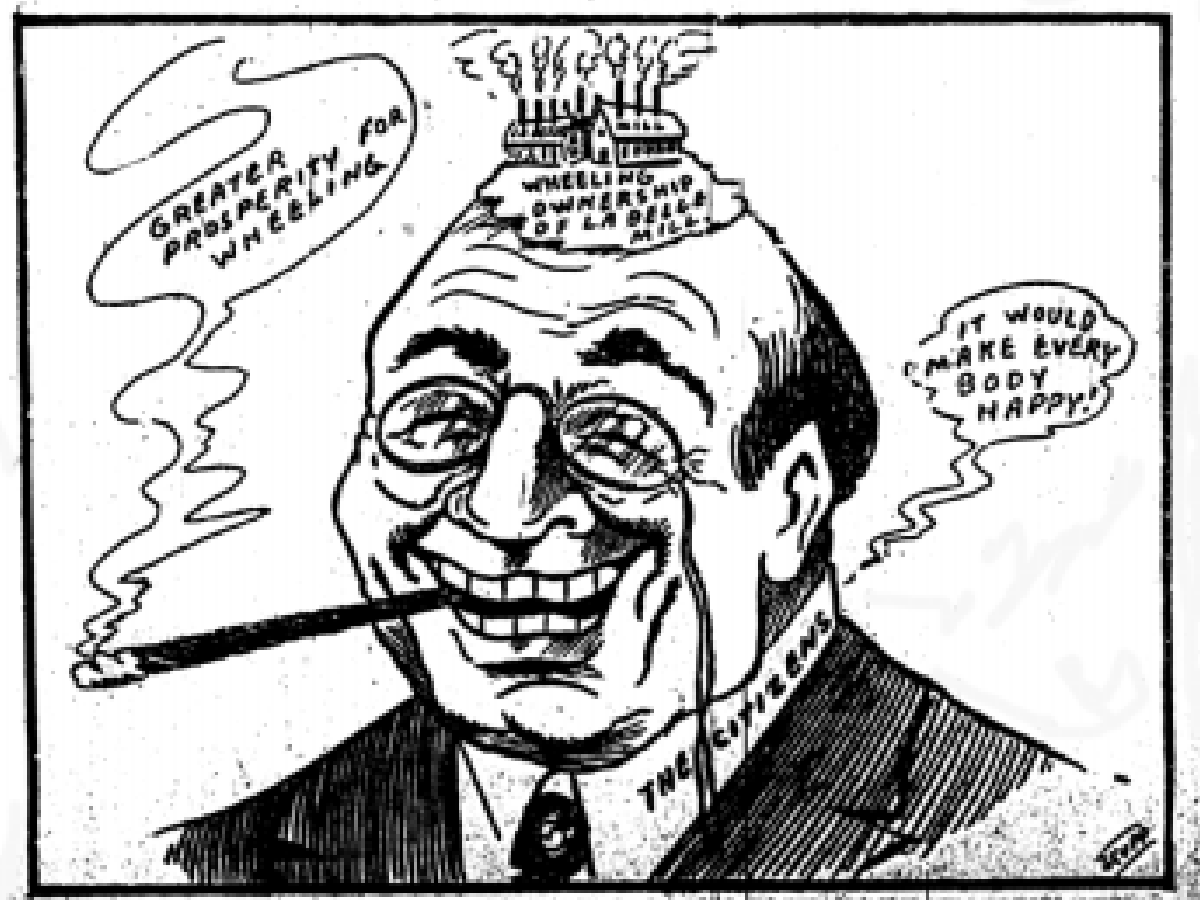



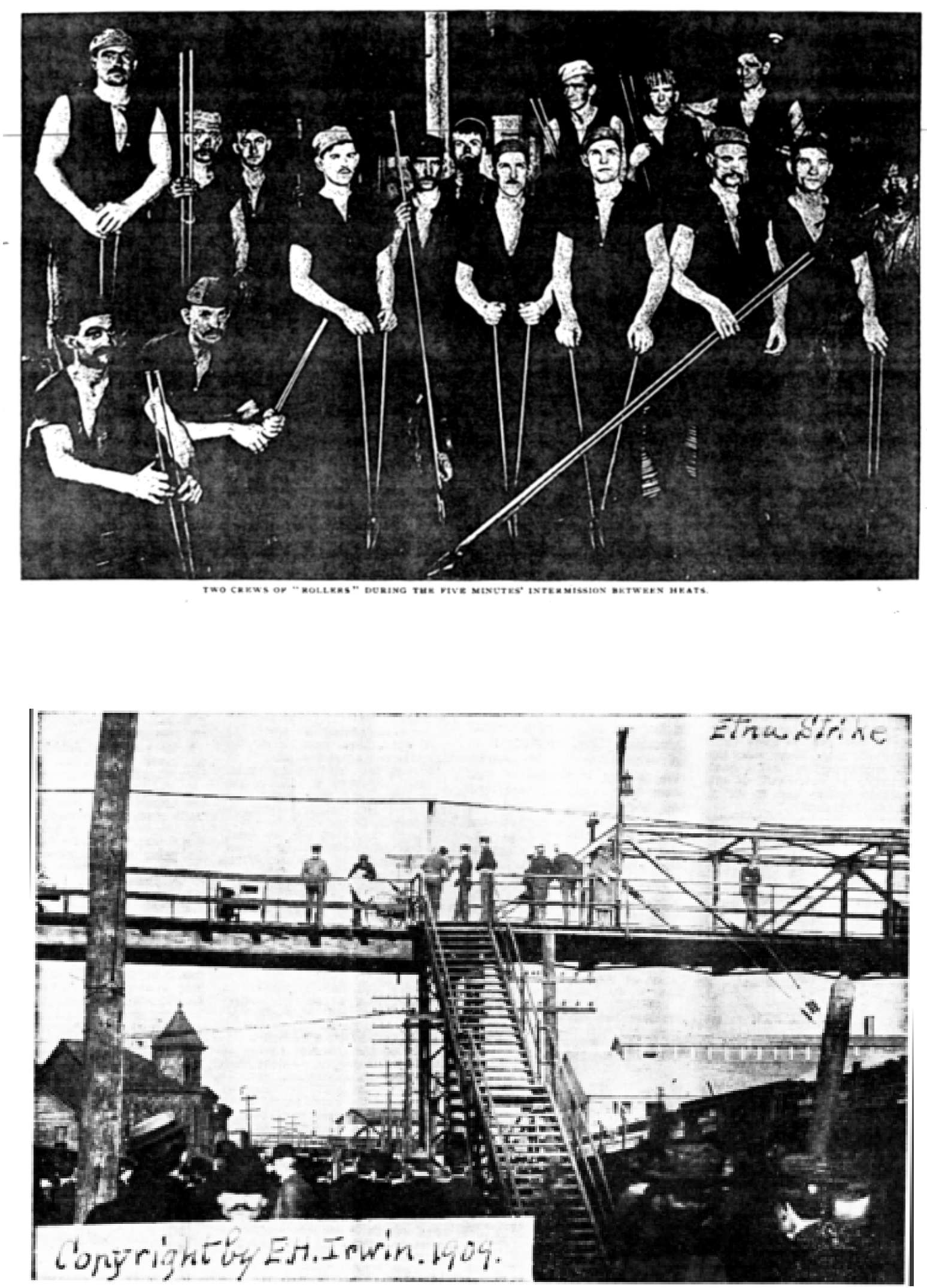


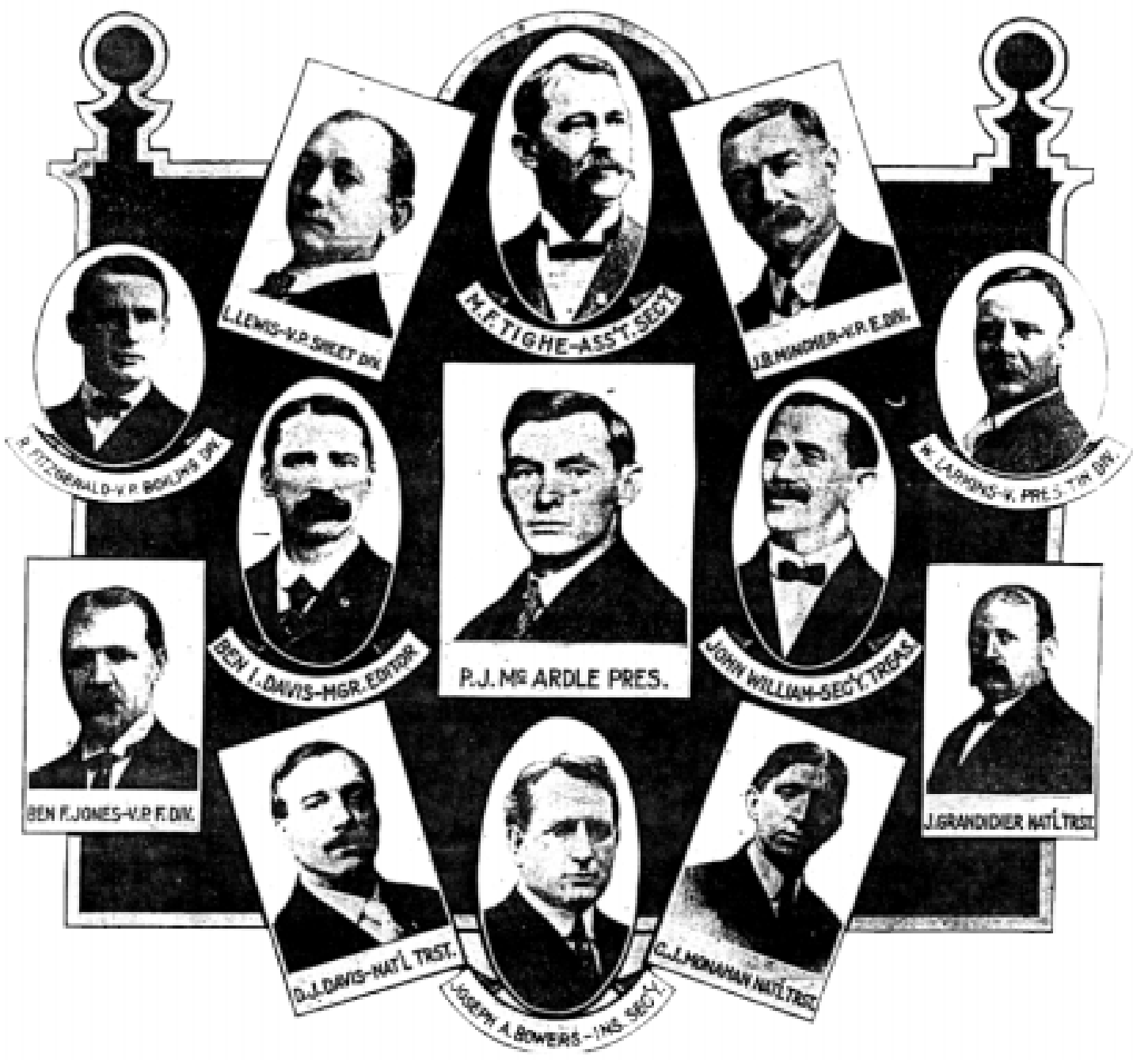




\section{Sheet and TIn Plate Mill Towns in the Wheeling District}

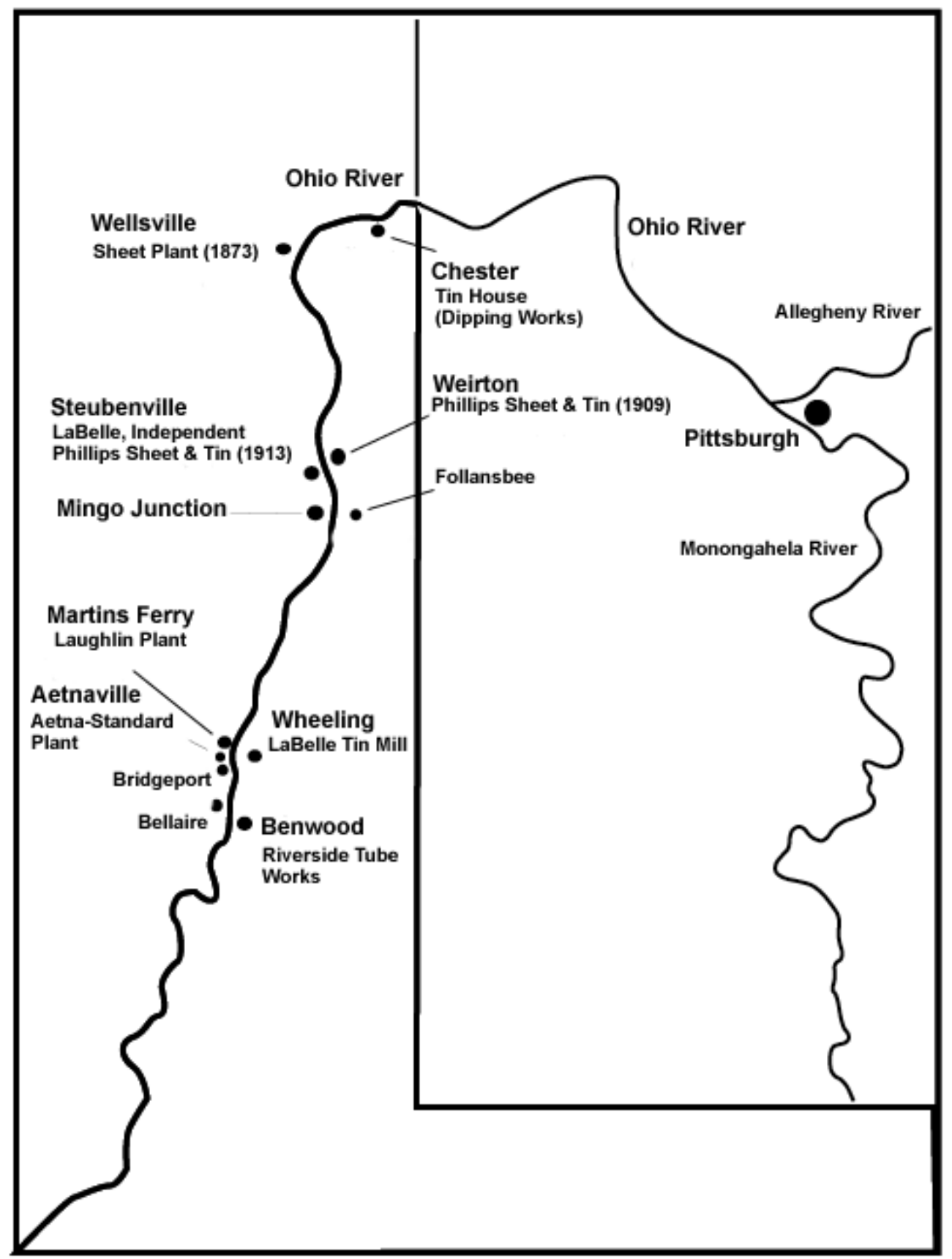




\section{Introduction}

On June 1, 1909, the workers of the LaBelle tin mill in Wheeling, West Virginia, arrived at work to find a notice announcing that after "careful consideration of the interests of both the company and its employees," commencing July 1 the mills of the American Sheet and Tin Plate Company would be run as "open" shops. ${ }^{1}$ Across the Ohio River in Aetnaville and Martins Ferry, Ohio, the same notice was posted on the Aetna-Standard and Laughlin plants, as well as the many other union plants of the company. At midnight on June 30, the contract between the Amalgamated Association of Iron, Steel, and Tin Workers and the American Sheet and Tin Plate Company expired, and the workers at the union plants walked out in a strike that would last fourteen months. It was the last chapter in a decade-long effort of the United States Steel Corporation, the parent company of American Sheet Steel and Tin Plate, to drive the union out of all its mills. When the strikers returned to work in the fall of 1910, not a single U. S. Steel plant remained unionized. ${ }^{2}$

Before the 1909-1910 strike, steelworkers in the Wheeling district had remained heavily organized while at a national level the union fell from its place of dominance in the early 1890s when the Amalgamated Association had about 24,000 members and represented about one-half of the steel industry. ${ }^{3}$ The turning point for the union was the 1892 Homestead strike, a defeat that led the way for other steel companies to break the union in their mills. In one mill after another in Pittsburgh, the companies drove the unions out until by 1901 all of the steel mills in Allegheny County, Pennsylvania, the largest steel producing county of the world, were non-

union. ${ }^{4}$ Whereas the union movement in the iron industry had started in Pittsburgh and spread out to all the secondary mill towns like Wheeling, now Pittsburgh led the open shop drive that spread and engulfed mill after mill, city after city.

The idea of the open shop was that the workplace would be open to both union and nonunion workers alike, but the company would not recognize the union nor sign a contract with one. While the open shop was not a new idea, it was now "invested with powerful ideological overtones." Management argued that collective bargaining denied individual workers the right to decide whether they wanted to be members of the union or not, but the open shop gave workers the opportunity to choose thereby protecting their individual liberty. ${ }^{6}$ However, the 
strikers in the Wheeling district, much like those in New Castle and other strike centers, viewed the open shop announcement of 1909 as the latest example of how the laboring classes were being disfranchised and oppressed by industrial capitalism. Their fortunes had not risen along with the industrial progress of the U. S. through the last decades of the nineteenth century and into the twentieth, and many steelworkers viewed their union as the only means of achieving a better life. With the loss of the strike, they found themselves divided allowing independent steel companies to adopt the open shop inaugurating the non-union era of the U. S. steel industry that lasted until the Great Depression. 


\section{Chapter One: Rise of the Tin Plate Industry in the Wheeling District}

Wheeling's industries developed steadily throughout the nineteenth century. Located on the Ohio River and the National Road, in the 1830s the town grew from a "minor commercial town" to a center for manufacturing. ${ }^{1}$ While its economy grew increasingly diverse with glass, pottery, and tobacco factories, iron became the primary industry, the one for which Wheeling became renown. With western territories being opened to settlement, the market for nails expanded consistently through the 1820s and 1830s, and established eastern nail companies were unable to compete in the western market because of the cost of shipping. Consequently, the number of eastern nails shipped west of the Allegheny Mountains "greatly diminished" while production in Pittsburgh and Wheeling increased. ${ }^{2}$ The Civil War brought "unprecedented activity and wealth" to Wheeling earning it the sobriquet of the "Nail City." As one historian describes the era following the war: "Vast armies had been mustered out and adventurous young Americans were scattering themselves out over the face of their half-developed country, following the railroads West across the prairies, building new homes by the million. Nails were in demand and the black smoke rolled in clouds from the chimneys of Wheeling's mills."3

Wheeling's iron industry grew even more when some of the local companies began to vertically integrate. Before 1857, all of the pig iron used in the Wheeling district was shipped down from Pittsburgh to be worked in local puddling furnaces. Afterward, completion of canals made it possible to ship iron ore from Minnesota across the Great Lakes and down to the Ohio River. This development, combined with the start of coke production in Connellsville, Pennsylvania, made it more economical to produce the pig iron in the Wheeling district blast furnaces than to buy it from Pittsburgh. ${ }^{4}$ Thus, local Wheeling district companies severed their dependence on Pittsburgh by converting the ore into pig iron in blast furnaces, puddling the pig iron into wrought iron, rolling the wrought iron into nail plate, and cutting the plates into nails all locally. The iron industry expanded south from Wheeling into Benwood and across the river into Bellaire, Aetnaville, Martins Ferry, Mingo Junction, and Steubenville, Ohio. The 1870s and early 1880s was the "golden age of puddled iron and of the cut nail" and all the towns of the Wheeling district were booming. ${ }^{5}$ 
The 1880s would witness the pinnacle and rapid decline of the cut nail. The decade began with the Chicago Tribune declaring that the "growth of Wheeling during the last ten years, considering the unprecedented depression in the iron business, is remarkable indeed." ${ }^{6}$ By 1885 , the Wheeling district boasted over 200 puddling furnaces, 1,400 nail machines, and an annual capacity of approximately 140,000 tons or $2,800,000$ kegs of nails. ${ }^{7}$ When the price of iron ore dropped from $\$ 13.03$ per ton in 1880 to $\$ 8.10$ in 1884 , the price of pig iron followed. Though this initially meant increased profits from cut nails, it also led to ruinous competition. The number of nail machines in the United States increased 43 percent, from 3,995 in 1882 to 5,695 in 1885 , and the increased competition led manufacturers to search for ways to cut costs. ${ }^{8}$

In Wheeling, manufacturers adopted the Bessemer steel process, thereby eliminating the puddlers, or boilers as they were sometimes called. Pig iron is brittle and unmalleable because of the impurities retained from the ore and the carbon picked up from the blast furnace fuel. Puddlers worked the pig iron in furnaces to burn out these impurities, producing blooms that were reheated and rolled into nail plate among other things. ${ }^{9}$ Puddlers learned their trade through an apprenticeship of several years. Having a relatively rare skill, they made a high wage, and, therefore, manufacturers saw tremendous savings in their elimination. The Bessemer process did not require skilled workers with years of experience. Henry Bessemer found that blowing air into molten pig iron burned out all the carbon impurities while keeping the metal molten. He also found that if the process were stopped at precisely the right time, steel was produced. Later, it was discovered that they could also make steel by burning out all the impurities and replacing a certain amount of carbon. This was a process controlled by managers, not workers.

Furthermore, it produced uniform metal, and on a large scale it could be done cheaper. ${ }^{10}$ Thus, the puddlers became obsolete, although a few thousand remained to produce a special high quality iron.

In the 1880s, Wheeling manufacturers began building Bessemer converters and cutting nails from steel plates instead of iron, thereby eliminating the need for puddlers. Unfortunately, this was not the life-saving, cost-cutting measure the companies had hoped it would be. The steel wire nail, as it turned out, eventually replaced the cut nail. Its cost was significantly less and quality better. Though Wheeling manufacturers had eliminated the highly paid puddlers when they began cutting nails from steel plates, they still could not compete with the wire nail 
manufacturers. In response, the Wheeling companies asked the nailers to take a pay reduction. They promptly refused, and a strike ensued bringing cut nail production to a halt and allowing the wire nail to capture nearly all of the nail market. ${ }^{11}$

Salvation for Wheeling's nail factory owners came in 1890 with the McKinley tariff. ${ }^{12}$ The tariff included duties on tin plate that had been produced previously in the United States, but American manufacturers could not compete with their Welsh counterparts. During the latter half of the nineteenth century, the tin plate industry exploded and Wales, at first, benefited the most. New uses were found for tin plate such as tin receptacles for tobacco, cigarettes, and candy, bottle caps, and especially canned food. The increase in the number of tin plate manufacturers and people employed in Wales is evidence of the "phenomenal growth" of the industry. Between 1860 and 1891, the number of Welsh establishments doubled from 40 to 80, and the number of people employed in the industry grew from 5,700 to 25,000. ${ }^{13}$ By 1890 , Wales was undoubtedly the world's center for tin plate production and encountered little competition from other countries.

After the tariff passed, the American tin plate industry grew rapidly. ${ }^{14}$ This was significant for the former cut nail producers since their rolling mills could be more easily converted to roll tin plate, whereas wire nails were the product of a completely different process. Since wire nails were formed from bars instead of sheets, cut nail companies would have had to retool their rolling mills as well as the nailing departments. Some companies had already switched to other products such as pipe, but the others quickly moved into the burgeoning tin plate industry. In the early and mid-1890s, the Wheeling Corrugating Company and the LaBelle Company, both of Wheeling, added tin mills, and across the river during the same period, the Aetna-Standard and the Laughlin Nail Works also added their own tin mills. ${ }^{15}$

Tin plate, simply put, is a "thin sheet of iron or steel coated with tin" and possessing "the strength of iron or steel without the liability to rust." ${ }^{16}$ (Terne plate, often produced in the same mills, differed only in that it was coated with an alloy of tin and lead.) The basic steel mills made ingots that were reduced in thickness in the rolls of the slabbing mills. The product, called steel slabs or sheet bar, was then brought to the hot mill of the tin plant. When they arrived they were six to ten inches wide, three-eighths of an inch thick, and twenty inches long. In the hot mill of the tin plate plant they were reduced to sheets of less than a tenth of an inch thick. ${ }^{17}$ 
These sheets were then coated with molten tin or terne. After that, they were cleaned, polished, boxed, and shipped out. The process was complicated and required some of the most highly skilled workers in the steel industry.

The production process in Wales as of 1890 was as follows: An individual mill consisted of two furnaces and two stands of rolls (a tin plate plant would have many such mills though they were often referred to collectively a single mill). First, the slabs were heated in the roughing furnace, removed in pairs when they were red hot, and sent through the first stand of rolls, the roughing rolls. The slabs would go through the roughing rolls alternately four or five times until they had been rolled into thin sheets of 8 B. G. (Birmingham Gauge) or 0.152 inches thick. During this stage, the furnaceman put the slabs in and decided when to take them out, the rollerman put the sheets into the rolls and adjusted the rolls, and the catcher, usually a young boy, gave them back to the rollerman after they had gone through the rolls. After being reheated in the same furnace, they were removed and put through the roughing rolls two more time which reduced them to 14 B. G. (0.0785 inches). To get the sheets down to the thin gauge required, the sheets would be paired, or stacked one on top of the other, and put through the rolls together. Toward that end, the fourth man on the crew, the doubler, would take the sheets and fold them in half, flattening the folded edge with a "crocodile" squeezer which was connected to a main drive shaft and ran continuously along with the rolls. Thus, the doubler would have to synchronize his movements with the squeezer. At this point the roughing was done, and the once-doubled sheets were put in the second, or "finishing," furnace for reheating. ${ }^{18}$

The sheets were then removed from the finishing furnace and passed through the finishing rolls. Again they were doubled (four sheets thick now and a total thickness of 0.0785 inches), and the edge was flattened in the squeezer. After reheating in the finishing furnace a second time, the same operation was repeated, making a pack of eight sheets. After a third and final reheating in the finishing furnace, the packs was passed through the finishing rolls until they were the required length. The standard final product was 20 inches by 42 inches, and cut into twenty-four sheets. ${ }^{19}$

From the hot mill, the sheets were then brought to the tin house. Here men, women, and children, some of whom were skilled and some not would finish the plates. The first operation of the tin house was shearing. When the packs of sheets had cooled, they were put into "crocodile" 
shears (as opposed to the "crocodile" squeezer). The shears were also connected to the main drive shaft thereby opening and closing continuously. As the sheets were cut to the right size, a boy would bundle up the scrap. Then the packs were sent to openers, women and young girls who separated the individual sheets from one another. The rolling and reheating process would slightly weld the sheets together. The openers would strike the corner of the pack against their workbench, which would bend it, and separate the sheets with a piece of metal they held in their hands. Sometimes a heavy knife was needed on the ones that were stuck. ${ }^{20}$

After being sheared and separated, the sheets would go to the pickling mill where a bath of sulfuric acid followed by one of water cleaned off the iron oxide that would build up on the surface of the sheets. The sheets were repacked before pickling and unpacked afterwards. At this point in the process the sheets are hard and brittle, so to make them tough they were put in the annealing furnaces. Seven or eight men packed them into cast-iron pots and conveyed the pots into the furnace on a "forked carriage." In the furnace the sheets were subjected to intense heat for ten to twelve hours before they were removed and sent to the cold-rolling department to be given a smooth surface. Becoming brittle yet again, the sheets had to be annealed a second time, called "white annealing." (The first annealing was called "black annealing.") Once again, iron oxide would have built up requiring a second pickling. The first pickling, called "black pickling," had a higher concentration of sulfuric acid than the second, or "white pickling.,"21

The product, called black plate at this point in the process, was now ready for tinning. At this time in Wales they used the "five-pot" process. The tinman, the washman, and the risers stood in front of a long brick "dresser" with a series of five vats. The first contained boiling palm oil, in which the plates were immersed for one to five minutes, and when they were removed, they were clean and more absorbent. The tinman would put the plates in the palm oil, determine how long they should remain there, and then transfer them to the second pot that contained molten tin. Again they remained for a few minutes, building up a layer of tin, before being transferred to the third pot. The third pot contained hotter and purer tin, and a second coat was imparted to the plate. Then the washman removed the plates and removed the excess tin before dipping them in the fourth pot that contained the purest tin. Finally, the riser put the plates in revolving rolls that went through boiling grease. The plates were removed from the fifth vat, and, while still hot, young girls would pass them through an absorbent cleaning material 
to remove the grease and then polish them with sheepskins. The tin plates were then sent to women called assorters to be inspected, packaged, and shipped out. ${ }^{22}$

By 1890 this process had undergone two centuries of evolution. There had been changes in pickling, annealing, tinning, and hot rolling. Originally, the black plates were pounded down to the proper thickness with hammers, but the sheets were not properly uniform. In 1728, a Welsh manufacturer developed the method of rolling the sheets, and the superior product of the Welsh mills began to displace tin plates produced elsewhere like Germany where hammers were still being used. ${ }^{23}$ The most important change of the nineteenth century was the introduction of steel; first Siemen's soft steel in 1875 then Bessemer steel in 1880. Because of its "greater ductility, superior tensile strength, and smooth surface," steel was far more suited to tin plate production than iron. ${ }^{24}$ But regardless of the changes in the process, the skill of the workers, developed and inherited over many years, was still essential. ${ }^{25}$

The tin plate industry though it had been established in the United States much earlier did not thrive until the McKinley tariff passed in 1890. One of the earliest efforts in this country was a small establishment in Philadelphia that began operations in 1830, but the inability to compete successfully with firmly established Welsh tin plate mills discouraged growth. ${ }^{26}$ It was not until 1873 that a tin plate mill was built in the U. S. to produce for the general market. The United States Iron and Tinplate Company and the American Tinplate Company were organized that year and built plants in McKeesport (near Pittsburgh) and Wellsville (north of Steubenville on the Ohio River), respectively. ${ }^{27}$ The American Tinplate Company sold their Wellsville works to W. Dewees Wood of McKeesport and, in October 1874, the plant discontinued production of tin plates. $^{28}$ When operations started up again in 1880, the new owners produced only fine grades of plate and sheet iron, without tinning them. The Wellsville plants later resumed production of black plates for tinning, but never again produced tin or terne plate at that plant. Other mills around the country were built, but like the Wellsville plant, met with little success in the tin plate industry. ${ }^{29}$

The McKinley tariff heralded the beginning of an era of tremendous growth in American tin plate production. Agitation had begun in the late 1870s for a tariff on tin plate, and chief among the agitators was W. C. Cronemeyer, secretary and business manager of the U. S. Iron and Tinplate Company. In June 1883, the American Tinned Plate Association was formed for the 
purpose of lobbying Congress to get the desired tariff. It was mainly comprised of sheet iron manufacturers hoping to expand their businesses. The Association paid Cronemeyer and Charles Gilpin, of the W. Dewees Company, an annual salary of $\$ 1000$ each to manage the organization's "propaganda." Their efforts came to fruition in 1890 when Cronemeyer was asked to testify before the Ways and Means Committee on the tariff. With the help of William McKinley the bill became law, and a 2.2 cents per pound duty on imported tin plate opened the U. S. market to domestic producers. ${ }^{30}$ Old mills were resurrected and new ones constructed. Production in America increased from 2,236,000 pounds in 1891 to $849,000,000$ pounds in $1900 .{ }^{31}$

The tariff was not the only reason for the growth of the tin plate industry. While it certainly provided the impetus for many to enter the industry, credit must also be given to the growing American steel industry in general. The rapidly falling price of steel up to that time encouraged growth in all the branches of the industry. ${ }^{32}$ Between 1871 and 1901, American steel manufacturers went from being inconsequential in comparison to Britain to eclipsing them. Annual pig iron production in the U. S. was not one-sixth of that of Britain, but by the end of that period the U. S. produced double that of British manufacturers. ${ }^{33}$ Regardless of the reason for its growth, the tin plate industry offered a new opportunity for many manufacturers.

By the time the tariff was passed, the cut nail business was in serious trouble. Wheeling district companies had recognized this after 1886, and the following year the directors of the Riverside mill in Benwood began building a pipe mill. In August 1887, operations began, and shortly thereafter it became the first plant to use Bessemer steel for pipes. ${ }^{34}$ The rest of the mills were looking for alternate products as well. As early as 1889, the Wheeling Iron and Nail Company, which operated what was known as the Top Mill, considered buying wire nail machinery from a mill in Syracuse, New York, but no action was taken, and as late as 1893 the LaBelle Iron Works investigated converting to the wire nail. The company president, Cecil A. Robinson, observed that the "cut nail is fast being driven from the market," and accordingly the directors sent the superintendent to Roanoke, Virginia to inspect a wire nail plant that was up for sale. Once again, no action was taken. ${ }^{35}$ By the end of this transformation, not one company had converted to steel wire nail production.

The first local company to start producing tin plate was the newly formed Aetna-Standard Iron and Steel Company, located in Aetnaville, an unincorporated town between Bridgeport and 
Martins Ferry. After the Aetna and Standard companies merged, they added a tinning department to the existing sheet and black plate mills and began turning out tin plate in May $1893 .^{36}$ Early in 1894, the Wheeling Corrugating Company started producing tin plate as well. Alexander Glass and E. C. Ewing formed the company in 1890 with $\$ 10,000$ capital. They began buying black plate from the Whitaker Iron Company, Ewing's employer of twenty years, and producing galvanized sheets and roofing. In February 1894, they added a tinning department. ${ }^{37}$ In 1894, the Laughlin Nail Company started work in Martins Ferry on a tin plate mill of five sets of hot mills and five sets of cold rolls as well as the accessory equipment for pickling and annealing. In 1895, the company built a tin house of eight stacks, and the first tin plate was produced that summer. ${ }^{38}$ Lastly, Cecil Robinson had submitted a proposal in November 1894, at the meeting of the directors that a tin plate plant of four hot mills be built. By July 1895, the LaBelle Iron Works had four hot mills, four stands of cold rolls, and six tinning stacks. ${ }^{39}$ A standard box of American tin plate full of sheets contained $105 \frac{1}{2}$ pounds of steel and $2 \frac{1 / 2}{2}$ pounds of tin. The LaBelle plant's capacity was 2,300 boxes of tin and 500 terne weekly with the black plate made in own rolling mill. Wheeling Corrugating Co. could produce 1,000 boxes tin and terne weekly on single shifts. ${ }^{40}$ The Laughlin plant had a weekly capacity of 3,600 boxes. ${ }^{41}$

Thus, in a few short years the focus of the iron and steel industry in the Wheeling district switched from nails to tin plate. The Laughlin and LaBelle companies built entirely new works for tin plate. The Whitaker and Aetna-Standard companies had already been in the sheet rolling business, and the Aetna-Standard company added a tinning department. The Wheeling Steel and Iron Company went into sheet steel production on a small scale. Bellaire and Mingo discarded nails and began manufacturing bars for sheet and tin plate mills because few of them produced their own bars. ${ }^{42}$ Additionally, small tin plate mills were built in Follansbee and Steubenville. A dipping plant (that did not produce its own black plate) was eventually built in Chester. And the Wellsville plant continued to produce sheet steel. Tin mills were also built during this period in Pennsylvania, Indiana, and throughout Ohio, which by 1900 ranked first, second, and third, respectively, in tin plate production in the United States. ${ }^{43}$

Between 1898 and 1901, the steel industry went through a dramatic series of mergers that resulted in the creation of U. S. Steel. ${ }^{44}$ The steel industry became increasingly competitive in the 1890s. The price of the steel billets, or slabs, that the tin plate companies consumed dropped 
from $\$ 1.52$ per 100 pounds in 1890 to $\$ 0.82$ in 1894 , and reached its low point of $\$ 0.75$ in $1897 .^{45}$ But while the tin plate industry continued to grow, urged on by these dropping prices, their prices dropped too. In one year the price per box of tin plate (100 - 108 pounds) dropped from $\$ 5.37$ in 1893 to $\$ 4.89$ in 1894 . By 1898 it reached a low point of $\$ 2.99{ }^{46}$ To exacerbate the condition, there was a severe business depression in the mid-1890s. ${ }^{47}$ Tin plate manufacturers found themselves in dire straits.

One tin plate executive later recalled that there was a "condition of excessive competition, which simply meant that the strongest people, financially, and the best plants, physically, would continue in existence, and some of the weaker ones would go into bankruptcy." ${ }^{, 48}$ Even the strongest were not realizing much return for their investment. Daniel G. Reid, who with W. B. Leeds owned the American Tin Plate Company of Elwood, Indiana, agreed that "the competition between the old companies had become so strong, the business was fast drifting into a condition where there was little, if any, profit. There was a number of mills losing money and very few of them making any, and it was a matter of the mills getting together."49

To reduce this cut-throat competition, tin firms moved to horizontally integrate the industry. The American Tin Plate Company was organized on December 15, 1898 with $\$ 46,000,000$ issued in capital stock bringing together "practically every tin-plate concern in the country." cases the "controlling inducement to sell out" was the extremely high price they could get for their plants, generally in the form of stock in the new corporation. ${ }^{51}$ It consolidated nearly forty different companies that, in all, had more than 275 mills. ${ }^{52}$ The company had dipping works in Pennsylvania (15), West Virginia (1), Ohio (9), Indiana (5), and Illinois (1). ${ }^{53}$ It employed between 20,000 and 25,000 people in $1899 .{ }^{54}$

In Wheeling, the tin mills of the LaBelle, Aetna-Standard, and Laughlin were all acquired by the new corporation. ${ }^{55}$ The directors of the LaBelle unanimously resolved to sell out for $\$ 500,000$ of preferred stock in the American Tin Plate Company, and the consent of the stockholders was formally recorded on November 22, 1898. In several cases, including all three of the Wheeling district plants, only the part of the property with the tin mill was purchased, 
leaving the rest of the plant to the original stockholders. ${ }^{56}$ The Wheeling Corrugating Company remained independent, as did the Whitaker-Glessner Company, which produced black plates.

The new company went through some quick changes. Some plants were shut down shortly after the merger while others were expanded and improved. In 1900, the company operated 31 tin or terne dipping plants and 34 that manufactured black sheets (some obviously did both). In the United States there were a total of 57 plants, meaning that the American Tin Plate Company operated more than half of them. Its daily capacity on single turn was 1,527,050 pounds of tin plate and 433,950 pounds of terne plate. On double turn, its annual capacity was $916,230,000$ pounds of tin plate and 260,370,000 pounds of terne plate. ${ }^{57}$ The American Tin Plate Company capacity in 1900 was almost as much as was produced in all of Wales in 1890, when that country led the world. ${ }^{58}$

According to one executive, investors "hoped that their plants would be bought and executives and superintendents hoped that they would be selected for fat jobs with the new companies." ${ }^{59}$ Some managers were fired, others promoted. William T. Graham, who was the president of the Aetna-Standard, became a vice-president of the American Tin Plate Company (Later, he became the president of American Sheet and Tin Plate Company and, later yet, president of the American Can Company). Cecil Robinson, formerly president of the LaBelle company became a district manager for the American Tin Plate Company, and Daniel Reid, who had owned the original plant in Elwood, became the president of the new corporation. ${ }^{60}$ Meanwhile, Cronemeyer, who had worked for so long to see the industry take root in the United States, was not offered a position.

The tin plate merger was only one of many. Early in 1900, the American Sheet Steel Company was organized with $\$ 49$ million issued in capital stock to "take over the principal manufacturers of steel sheets." ${ }^{61}$ Other "finishing" mill mergers included the American Steel and Wire Company, American Steel Hoop Company, and National Tube Company. The sheet mill of the Aetna-Standard was bought by the American Sheet Steel Company, and the Riverside mill was bought by the National Tube Company. In basic steel, the big three were Federal Steel, National Steel, and Carnegie Steel. National Steel was closely associated with the American Tin Plate and American Sheet Steel companies, supplying the two finishing companies with basic steel. In order to compete with National, Federal and Carnegie Steel also began to invest in 
finishing mills. When they all looked into expanding their companies to integrate transportation and ore, company heads recognized that a new period of competition was beginning that might mean the end of one or more of the enormous corporations. Since the elimination of competition had been one of the critical reasons for the mergers in the first place, the giants of the industry began to look for a way to avoid unnecessary competition. The result was the United States Steel Corporation. $^{62}$

J. P. Morgan, perhaps the most powerful financier in the world, took an interest in seeing the corporation created. The other interested parties, Elbert Gary of National Steel, Charles Schwab of the Carnegie empire, and Judge William Moore who had arranged the tin plate merger, all stood to gain by its creation. The only stumbling block was Andrew Carnegie, without whose company the colossus would be incomplete. Once Carnegie agreed to sell his company for $\$ 200$ million, everything else fell into place. Carnegie embarked on his philanthropy career, Morgan became the final authority in the steel industry, and Schwab and Gary were left to run the industry on a day to day basis. ${ }^{63}$

U. S. Steel brought more than half the iron and steel industry under one management. Granted, U. S. Steel ostensibly did not produce a single ton of steel as it was only a holding company, but there was little doubt that the executives of the corporation would closely oversee the operations of all its subsidiaries. While each president would retain control over their subsidiary, they would report to the new board of directors. Certainly there would be a lack of uniformity at first, but the ultimate goal of the corporation would be to bring order to an industry that had been so chaotic for so long. It was the first billion-dollar company and the most extensive the United States had seen. At the time of its organization, it had an annual production capacity of over 9.4 million tons of crude steel, 7.7 million tons of finished, rolled steel products, several railroads with over 1,000 miles of track, a fleet of 112 lake ore vessels, between 500 and 700 millions tons of iron ore resources, over 50,000 acres of coking-coal lands, and a great acreage of lands with other grades of coal. ${ }^{64}$ Included in this empire were eight (Wellsville, Chester, Mingo, Martins Ferry, Aetnaville, Wheeling, Benwood) plants on the Ohio River between Wellsville, Ohio and Benwood, West Virginia.

Henry Scott, an executive for the Wheeling Steel Corporation, later wrote:

The local plants that were bought by [U. S. Steel's] subsidiaries necessarily lost their purely local character and much of their historical importance to us. They came to be 
directed from Pittsburgh or New York by men with little knowledge of or interest in Wheeling. They became cogs in a big machine, a machine in which the cogs have to justify their existence by cold figures. A billion-dollar corporation that must earn dividends for its stockholders, that has unlimited resources and is tied to no district sentiment or investment, will consider each community according to its economic location and its temper with respect to labor. Aside from soft coal, Wheeling has no raw material to offer, and she is not advantageously situated with relation to important markets. The United States Steel Corporation has not increased its capacity in this district. $^{65}$ 


\section{Chapter Two: The Decline of the Amalgamated Association of Iron, Steel, and Tin Workers}

Traditionally, workers in the iron and steel industry had controlled virtually every aspect of the conditions of their employment, but as the nineteenth century drew to a close they saw that control diminish greatly. Up to the 1870s, they determined how they would produce the iron and how much they would produce. Skilled workers even determined who would be on their crew. Puddlers, rollers, and the other skilled men worked directly for the company while their crew worked for them. ${ }^{1}$ Seemingly, the only question that remained was how much they would get paid, and even the way this was determined changed considerably. Miles Humphreys, the president of the puddlers' union, the Sons of Vulcan designed the first sliding scale, which was signed in 1865. It based the puddlers' wages on the price of bar iron, and, in turn, the workers were paid according to how much they produced. Humphreys later recalled that the "cost of living and the cost of production did not enter into the consideration at all; only a fair proportion of the profits or of the selling price." ${ }^{2}$

In the 1870s, as employers united in organizations for the purpose of dealing more effectively with unions, the various craft unions found themselves at a disadvantage. In 1874-75, the manufacturers in Pittsburgh shut down their mills in an attempt to break the Sons of Vulcan. They were able to start mills back up with "black sheep," or non-union workers; in this case, the skilled ex-slaves from eastern Virginia were brought in to puddle the wrought iron. The rollers, heaters, and other finishers at the mills did not object and continued to work with the non-union iron. "You are enabling the manufacturers to fight the boilers," pleaded one puddler warning that if the puddlers were to lose the lockout that the other finishers "would next be attacked and reduced." ${ }^{3}$ The puddlers finally won the struggle, but it revealed the weakness of being organized in separate craft unions. ${ }^{4}$ In 1876, just a year after the lockout ended, the Amalgamated Association of Iron and Steel Workers was formed, bringing together the unions of the puddlers, rollers, heaters, and nailers into one organization. By the late 1880s, it became what was probably the most powerful trade union in the United States. The Amalgamated 
Association was well suited to the iron industry and even had a stabilizing effect on it, but it was an organization "posited on an industry whose methods were fixed, manual, and uniform."5

By the 1892 Homestead strike, all had changed. As a result of the introduction of the Bessemer converter, the skill of the worker was no longer the determining factor in the quality or quantity of the product produced. Thus, there was no longer an exclusive, elite set of men on which manufacturers had to rely. One British steel executive noted that the "various operations are so much simplified that an experienced man is not required ... The workmen in America do not act upon their own judgement, but carry out the instructions given to them."6

With the erosion of their skill, workers also witnessed the erosion of their control over the iron and steel industry. The Bessemer steel process set in motion a series of improvements that would wrest control away from the workers. John Jarrett, who was elected president of the union in 1880, said that the introduction of the Bessemer steel process had resulted in the "complete subjugation of labor to the will of the employers."7 The Amalgamated Association tried to accommodate to the employers. "The Association never objects to improvement," President William Weihe said in 1894. If changes "do away with certain jobs they make no objection. They believe in the American idea that the genius of the country should not be retarded." 8 Unfortunately for the union, the new process did more than simply "do away with certain jobs." It completely changed the industry. The Bessemer process was not based on the accumulated experience or skill of the worker, but instead on the mechanics of the process. Managers determined the length of the blast, the amount of carbon to put back into the molten iron, and, thus, the quality of the product. By gaining control of the process, managers also found that they could dictate how much they would produce. Iron puddlers would generally made 550 pounds of iron per heat and depending on the furnace and materials could usually fit five heats into a twelve hour shift. ${ }^{9}$ In the new steel plants, Bessemer converters could produce five, ten, or fifteen tons of steel in one blow of about fifteen minutes. ${ }^{10}$ Changes were not confined to the production of the steel at the converters. Managers found that steel, being uniform, was well suited to mechanization throughout the industry. Rolling mills were made into continuous operations, and more skill was eliminated. No longer did rollers in basic steel mills have to make judgments based on the heat of the metal, the conditions of the rolls, and the quality of the iron. In the continuous rolling mills, steel was passed through a series of rolls, and the workers did little 
more than replace worn-down rolls. During a twelve-hour shift in a slabbing mill, three men now supervised the rolling of 600 to 1,000 tons of steel. ${ }^{11}$ Charles Schwab, a product of Andrew Carnegie's promotion system, claimed he could take a "green hand," an intelligent farm worker for example, and make a melter of him in six or eight weeks. This is what enabled companies to import strikebreakers to restart their mills. ${ }^{12}$ The mills of the past were filled with men of long experience, but now, workers were more easily replaceable.

The only voice workers had in the conditions of their employment was through the might of their union, and, as John Fitch observed in his study published in 1910, the story of the union in the steel industry is the story of Homestead. ${ }^{13}$ The Homestead plant was built in 1881 and purchased by Andrew Carnegie a few years thereafter. The Carnegie Steel Company became unique in the industry, and where the "great Carnegie Steel Company led, the others had to follow." 14 Indeed, Carnegie had been leading the industry almost since he entered it in 1873 when the Edgar Thomson works, his first, was built. Carnegie's obsession with cost reduction led to a higher rate of technological improvement, a higher rate of production, and greatly increased competition among steel manufacturers in general. Pools for output restriction and price fixing were commonly formed with the hopes of bringing stability to the industry, but they frequently fell apart when one party, often Carnegie, had an advantage over the rest. Those companies who fell behind in the competition were usually forced into bankruptcy while the others remained profitable. The high pitch of competition combined with a fluctuating and unpredictable market for steel products imbued on manufacturers the need to economize their operations, and again, Carnegie led the way. In 1897, a year when many plants were forced to shut down, Carnegie Steel made $\$ 7$ million in profits. ${ }^{15}$

Through the 1880s the Amalgamated Association of Iron and Steel Workers had expended a great deal of effort to organize the mills of the great Carnegie empire. They had been unable to gain a foothold in any plant built specifically for steel production. The large plants of Jones and Laughlin in Pittsburgh were unionized, but the locals were established before the transition to steel. With the Carnegie Steel Company it was a different story. Locals were established at the Edgar Thomson plant in Braddock only to be broken, and the same was true at the mills of the Duquesne plant. ${ }^{16}$ 
The only successful campaign was at Homestead where, by 1892, there were eight lodges established and active. A problem arose over wages in 1889, and, through much negotiation, was settled with a temporary measure and a contract was signed for three years. With each new improvement in the process, for which Carnegie was renowned, labor and management struggled over what portion of the increased production should be paid to the men. Schwab pointed out that no longer was increased physical exertion the reason for increased production. Increased production was based on enormous capital expenditures, and, for this reason, the benefit should go to the company. ${ }^{17}$ With this in mind, the wage committee and the managers of the company sat again at the negotiating table in 1892 .

By this time, wages were not the only point of contention. Management had grown increasingly frustrated with the union. Being "in the saddle," the union was often able to impose its will on the company, and union officials were inflexible on many issues that were of paramount importance to foremen, superintendents, and executives. Firstly, they were resistant to changing the footnotes of the wage scale agreement that governed the workshop, job descriptions, production restrictions, and procedure in general. ${ }^{18}$ This was more than a nuisance to the managers as they competed with one another to modify the process, produce more, and increase profits. Furthermore, many frivolous grievances were brought before management, and because of the union's clout all of the grievances had to be addressed. This abuse of power undoubtedly left resentment among management for the whole process and not merely for the individual claims they believed to be frivolous. ${ }^{19}$ Employers frequently complained that when faced with a strong union they were not free to manage their own business. ${ }^{20}$

Thus, Carnegie Steel's management had many reasons to dislike the union, and they determined that the union must be broken. When the 1892 negotiations began, Andrew Carnegie left the country for an extended vacation in Scotland, leaving Henry Frick who was already known as "the implacable foe of organized labor" from his days as owner of the Frick Coke Company, responsible for dealing with the union. ${ }^{21} \mathrm{He}$ made wage offers that were far below what the wage committee could accept, and even when the committee was ready to compromise he again undercut their offer, forcing the union to declare a strike. While it seemed that the strike was over wages, most knew that it was, in fact, over the right of the workers to organize. 
Before negotiations had even ended, Frick had contacted the Pinkerton Detective Agency to send two hundred men to protect the strikebreakers who he intended to import. When the strikers discovered that the Pinkertons were approaching on barges on the Monogahela River, a gunfight ensued and several people were killed. Pinned down, the Pinkertons surrendered under the condition that they would be safely transported out of town. Strike leaders agreed, but when the march of the now unarmed Pinkertons began down the streets of Homestead, violence erupted. While Frick had been previously unable to convince the Pennsylvania governor to send the militia, he now had his excuse. The town was in chaos, and lives and property were at risk. The militia arrived and took control of the town. The strikers had expected the Pinkertons would be tried for murder, but none were. In fact, the strikers were the ones tried as criminals. If there had been any doubt on whose side the government stood, it was now quite clear that the state had aligned itself with the Carnegie Steel Company. ${ }^{22}$

Reeling from the company's display of influence, power, and overt force, the Amalgamated Association refocused its efforts. No longer believing that they could trade blows with large, influential companies, they focused on that which had given them strength in the past -- their skill. Having always been a union almost entirely comprised of skilled workers, the union leaders saw strength in their skill. Even at Homestead, only skilled men had been organized, and the union simply had to count on the cooperation of the unskilled workers employed at the plant. Mills that still relied heavily on skill were less able than the Homestead plant to use strikebreakers during labor conflict. If skilled workers were needed and they went on strike, no number of detectives and militia could start the mills up again. Essentially giving basic steel up as a lost cause, union officials sought to organize and retain the less technologically advanced finishing mills, which included the sheet and tin plate mills.

The assault on the power of the workers continued through the rest of the 1890s. Labor saving devices reduced the number of unskilled workers needed, and other improvements continued to reduce the need for skill. Furthermore, Eastern European immigrants were being brought in to work the unskilled positions. They were initially a cheap and plentiful source of labor, willing to work for starvation wages, but management reaped another benefit from them. Americans and old immigrant workers, such as the Germans and British, harbored prejudice and animosity toward the Eastern Europeans. They did not speak English, did not come from trade 
union traditions (in fact most came from agricultural occupations in their former homes), and a seemingly "unbridgeable gulf" separated them. ${ }^{23}$ Through their efforts to organize the Americans, German, Irish, and Welsh employed in the finishing mills, the Amalgamated Association began to recoup some of its membership losses by the late $1890 \mathrm{~s}^{24}$ Tin plate, in particular, was especially well suited to the union because it still relied on skilled workers.

W. C. Cronemeyer claimed that "as soon as the manufacture of tin plates was commenced in the United States, American enterprise and inventive genius took up the matter of introducing improvements so as to reduce the labor involved, cheapen the cost of manufacture, and lessen consumption of raw materials." 25 While changes were made, they did not radically change the process. For example, commonly in 1895, crews of laborers unloaded the slabs upon arrival at the plant and put them on buggies. The buggies were then pulled and pushed by other crews to the furnace. By 1910, it was common for cranes to do all the unloading, and narrow-gauge locomotives to take the slabs to the furnace. ${ }^{26}$ Again, whereas crews of laborers would put the slabs in the furnace and remove them, called "charging" and "drawing," by 1910 one man operated an electrically driven charging machine. ${ }^{27}$ Likewise, automatic roll tables and roller conveyors replaced the need for laborers to transport the plates within the plant, from the furnace to the rolls and from the rolls to the tin house. ${ }^{28}$ The use of electric cranes, according to Cronemeyer, was one of the most valuable improvements. ${ }^{29}$

American manufacturers also made improvements to the existing equipment that increased output. For example, whereas Welsh rolls were nineteen inches in diameter and twenty-four inches long, Americans, by 1895, had increased these dimensions to twenty-four inches in diameter and thirty-inches in length. The larger rolls increased the pressure on the packs, enabling sheets to be rolled longer and thinner per pass, and the rolls retained heat better cutting down stoppages due to cracked rolls. Americans were also able to cut the number of passes from five to four. The larger machinery increased the mill crew from four to seven with the addition of the roller's helper (or screw man), doubler's helper, and heater's helper. ${ }^{30}$ Even with larger crews, between 1895 and 1910, the output per man in the plate mills increased from 1.15 to 5.96 tons per day. ${ }^{31}$

Incidentally, this was not applauded by all. Can manufacturers complained that the tin plate now produced by American manufacturers was no longer as high in quality as that formerly 
produced in Wales. One complaint was the reduced amount of tin used. Whereas five pounds of tin were previously the standard amount used per one hundred pounds of steel, now only two and one half were used. The result, according to one canner, was that the "coating is very thin, that in opening the tin, you would find the can more discolored inside," thereby making food and other products less appealing. ${ }^{32}$

While cranes and the other improvements reduced the number of strong backs needed and increased output, management still had to depend on highly skilled workers in the hot mill and semi-skilled workers in the tin house. To establish plants in the United States, manufacturers imported skilled Welsh workers who "brought over to America the traditions of strongly organized labor."33 The heater, called the furnaceman in Wales, was a highly skilled worker and required "long experience and considerable practical knowledge of the heat treatment of metals." Furnace temperatures were "judged largely by the heater's eye," and a single error meant the "loss of a valuable steel slab.", The roller in sheet steel and tin plate mills was another occupation that remained virtually unaffected by the changes in the mills. One description of the job states:

This is a very responsible and highly skilled occupation, which requires a special knowledge of the working of iron and steel that can be gained only by long experience. It is impossible to convey in a description the kind and degree of knowledge required to produce uniform plates of the proper width and thickness on which the loss shall be as little as possible. The roller must be able to direct the heater when the slabs are not heated properly. There is no heavy manual labor required except during roll changes or when there is trouble in rolling. ${ }^{35}$

One company executive conservatively estimated that if a worker was "real clever he can learn the business in 3 years from the time he starts in." 36 Thus, while improvements being made in the rest of the steel industry were reducing the dependence on skilled workers, in the hot mills of the tin plate plants skill was still essential.

When the American Tin Plate Company was created, six of the plants were non-union, but all but one of these were organized after a "token strike." The large Monessen plant was the only one not included in the wage agreement. The company insisted that the union make an exception for the Monessen plant because they were attempting to roll tin plate continuously there, and, hence, a negotiated wage that applied at all the other plants could be problematic at one where a new process was in place. ${ }^{37}$ The union agreed to this, and, at first, the mergers did 
not seem to have been terribly detrimental to the Amalgamated Association. Common laborers, in fact, seemed to benefit from it as their wages advanced up to 20 percent at some mills because the company had to bring some plants up to the scale rate. ${ }^{38}$ If union leaders put blinders on and only saw their small corner of the whole iron and steel industry, they could be pleased with their organization. The American Tin Plate Company like the other finishing companies relied on their skill and granted them plants that had not been previously union.

In the tin house, however, improvements were being made that lessened the need for skilled workers. The application of the tin coating as it was done in 1890 was by no means mechanical, and everything had to be done in a particular way for a particular amount of time. ${ }^{39}$ Improvements in this area came from Welsh manufacturers not Americans. First, zinc chloride or tinning flux, as it was called, replaced the boiling palm oil because the flux was faster acting. Because of this, there was no need for an extra pot. Instead, the flux floated on top of the molten tin, and a machine, loaded with plates, submerged them in the molten tin, passing through them through a layer of the flux. Furthermore, the revolving rolls of the machine regulated the amount of tin imparted to the plates. Thus, the tinning machine replaced skilled workers in the tin house. ${ }^{40}$ As for the unskilled, they had to handle the plates while they were still hot and suffer in the poorly lit and extremely hot mill. The young women that polished the plates were paid $\$ 1.10$ per 100 boxes of 56 plates they polished, but the average output per day was between 50 and 60 boxes. Thus, the unskilled workers were subjected to poor conditions for less than a dollar a day. $^{41}$

To try to better these conditions, the tin house workers formed the Tin Plate Workers' International Protective Association of America (TPWIPA). Their first convention met in Columbus, Ohio in 1899. ${ }^{42}$ The TPWIPA was comprised of "tin men, risers, tin plate openers, picklers, assorters, boxers, reckoners, tin house shearmen and all men working in tin houses, and all men identified with our craft, except foremen."43 The Amalgamated Association leaders had advised the tin house workers to form their own union because they would better be able to protect their interests. ${ }^{44}$ The original 1876 constitution of the Amalgamated Association had excluded their membership to "Puddlers, Boilers, Heaters, Roll Hands, Nailors, Hammermen and Helpers." 45 The following year "Tin-men, Picklers, Annealers, Washmen, Assorters, Hot and Cold Staighteners, and Shearmen working by the ton" was added to the list, and the name of the 
union was changed to the Amalgamated Association of Iron, Steel, and Tin Workers. ${ }^{46}$ In 1879 , "Tin" was dropped from the name of the union, but the tin-men, washmen, assorters, and the other tin house workers remained under their stated jurisdiction. ${ }^{47}$ In 1889 , after years of an increasingly more liberal inclusion of mill workers in the jurisdiction, the constitution was changed to simply read "all men working in and around Rolling mills, Steel works, Nail, Tack, Spike, Bolt and Nut factories, Pipe mills, and all works run in connection with the same, except laborers, the latter to be admitted at the discretion of the Subordinate Lodge."48 "Tin" continued to be omitted from the name of the union until 1898, but, as the TPWIPA was formed that year, it must have been included as reference to the men of the hot mills specifically. Despite being explicitly included in the early constitutions and implicitly included after 1889, the tin house men and women remained largely unorganized until 1898. Of the 21 tin plate plants in the U. S. in 1898, the tinning departments in only six of those plants were organized. That year, Samuel Gompers issued a call for a convention in Kansas City to create a national organization of the tin house workers. Nine delegates from the six locals met in December, and on January 17, 1899, the TPWIPA was created. ${ }^{49}$

The tin house workers considered some among their ranks to be skilled and others unskilled. The question arose in the TPWIPA whether or not they should permit unskilled workers, and officials contacted Samuel Gompers, president of the American Federation of Labor (AFL), to find out what his thoughts on the subject were. Gompers advised them to accept the unskilled workers as labor organizations should be broad embracing the principle of the brotherhood of men. He also warned them that if unskilled workers were refused membership that that would come back to haunt them in times of trouble as companies would try to use those workers to fill vacated jobs, as they were presumably somewhat familiar with various jobs around the mill. Thus, the TPWIPA accepted unskilled workers including women. ${ }^{50}$

Many predicted the TPWIPA would fail because their numbers were limited and they had little trade union experience, but by their second convention in May, 1900, the union had thirty different lodges. "S1 "Strength does not always find its seat in a large membership," said George Powell, president of the union in 1900, "but its efficiency lies in the righteousness of its cause. Second, in the intelligence of its members to understand trade-union principles. Third, the devotion of the membership in upholding them at any cost. Fourth, the great interest the 
members take in the affairs of the organization and their acquaintance with all the details connected with it." ${ }^{, 52}$ The TPWIPA had survived a rash of strikes against the American Tin Plate Company for recognition, which they won. Mistakes admittedly had been made, and the wages negotiated with the company, due to the variances in the mills, hurt some members and unfairly benefited others. They had still, however, gained recognition, which, as Powell pointed out, was something "that the men of the Carnegie mills, of Pittsburgh and vicinity, have been trying to obtain for years." 53 Additionally, before the TPWIPA got their first scale signed, many of the tin house workers were working twelve hour shifts. By 1903, no tinners or risers worked longer than ten hours on the day shift and eleven on the night shift, and more than thirty percent of them had secured eight hour shifts. The president in 1903, Charles Lawyer, said that the union's "pathway has not been strewn with flowers, by any means," but they had accomplished a great deal in a short amount of time. ${ }^{54}$

Both the Amalgamated Association and the TPWIPA had at first viewed the American Tin Plate Company with considerable anxiety believing that the "concentration of so much capital into the hands of one dictatorial management naturally gives it power to drive a hard bargain and often an unfair one with labor." After their unions were recognized and their contracts were renewed, the workers were relieved, but this relief was short-lived. When orders slacked off, more of them than ever found themselves idle. Before, when demand declined, at least the independents would try to continue operations to get their share of the market, but with the corporation, it was more logical to shut down whole plants rather than run several part time. Workers responded: "What is only economy to you is starvation to us." Furthermore, management could be very selective in choosing which plants to run leading one tin plate worker to complain: "Ostensibly we are idle through want of orders, but as a matter of fact we are locked out because we will not work at a lower rate of wages, as do the men of Monessen, nor turn out a larger output, as do the men of New Castle," both of which were in violation of the union's constitution. The workers' opinion of the mergers was simple: "If the American Tin Plate Company can not practice its economies without the wholesale shutting down of mills, and throwing hundreds of its employees out of employment, if it can not pay dividends on its enormous issued stock without causing so much human suffering, then we say that the trust is more of a curse than a blessing." 55 
The strategy of shutting down whole plants was used to an even greater extent by the American Sheet Steel Company and its first president George McMurtry. Sheet steel was a generic term that included black plate production, and the American Sheet Steel Company formed in 1900 to consolidate the production of most of the nation's sheet steel. While the American Tin Plate Company owned the tinning department of the Aetna-Standard, for example, its sheet steel mill was owned by the American Sheet Steel Company. ${ }^{56}$ By that time, the Amalgamated Association had organized twenty of the twenty-seven plants of the American Sheet Steel Company. Its seven non-union mills ran to full capacity during 1900-1901, while nine of the union mills sat idle. ${ }^{57}$ The company's president, McMurtry, was much more notorious for being anti-labor, and, naturally, many thought this was the reason for the selection of plants to be run full. In essence, the companies tempted workers to break union restrictions on output and work for rates less than the union negotiated with the promise that their mill would resume production. Rather than give tacit approval to violations or risk mutiny by fining members, the Amalgamated Association amended their constitution at the 1900 convention to read that "should one mill in a combine or trust have a difficulty, all mills in said combine or trust shall cease work until such grievance is settled." 58 This measure was designed to bring uniformity back to the working conditions in the various plants, but in effect it would later handcuff union negotiators who would have to demand that all the mills of a particular corporation be included in the agreement.

The Wheeling district, now almost entirely geared toward sheet and tin plate production, remained extensively organized. By 1900, from Wellsville down the Ohio River to Benwood there were six complete tin plate plants, two dipping works (tin houses that were not attached to a hot mill), two sheet mills (that made black plates without tinning them), and two plants that made sheet bar. Laughlin and Aetna-Standard each employed 2,000, and the LaBelle employed 500, and all were represented by Amalgamated lodges. There were two TPWIPA lodges in Martins Ferry (Standard Lodge No. 9 and Ohio Valley Lodge No. 12) and one in Wheeling (Powell Lodge No. 8). ${ }^{59}$ In 1899, organizer Thomas J. Irwin of Martins Ferry reported that their TPWIPA local had secured the eight-hour day and an increase in wages. ${ }^{60}$ From the workers perspective, the Wheeling district was solid. 
The creation of U. S. Steel in 1901, however, brought new insecurities. The first question was whether their plant would be kept running or whether it would be dismantled in the name of efficiency. In May, 1901, President Charles Schwab took a tour of the Ohio Valley to visit the mills to decide that very matter. His party went first to the Chester plant, the fate of which had been uncertain for some time. Aboard a special train, Schwab and his party then crossed the river to inspect the Wellsville plant, then continued down to Steubenville, Mingo Junction, Aetnaville, Bellaire, and finally to Wheeling. Rumors that the Chester plant would be moved in its entirety to Vandergrift, Pennsylvania, turned out to be false. All the mills Schwab inspected were to remain in operation. ${ }^{61}$

Meanwhile, at the end of May, the Amalgamated Association was holding its annual convention in Milwaukee. "It goes without saying that this is perhaps the most important convention in the Association's history," the National Labor Tribune declared. As the constitution had been amended the previous year to insist that companies sign for all their mills, the only question left as the amendment dictated was whether the wage scale committee should meet only with representatives of U. S. Steel itself or if they should agree to meet with representatives of the subsidiaries. ${ }^{62}$ Ultimately they agreed on the latter.

The executives of U.S. Steel had two main priorities: bringing uniformity to the policies of their subsidiaries and reassuring the public that the new corporation was good for America. The recent merger wave had brought a negative reaction from the public and the government, who were opposed to monopolies, and U. S. Steel bordered on being just that. Executives argued that the corporation was a purely a holding company owning the stock of the subsidiaries and not, in reality, producing a single ton of steel. Bringing uniformity too swiftly or indelicately might strengthen the perception that the new trust did, in fact, dictate the policies of the subsidiaries and, therefore, was a monopoly that posed a threat to fair competition. U. S. Steel's executive had to be very diplomatic in their decisions during the early months of the corporation's history. ${ }^{63}$

The officials on the Executive Committee of U. S. Steel also had contradictory philosophies which fueled much debate at their meetings. Like the union, they were also trying to decide on a course of action in preparation for the upcoming scale negotiations. At the time, the Amalgamated Association was very strong in about one-third of the corporation's plants. U. 
S. Steel officials agreed that strikes had to be avoided in the early months, and they instructed subsidiary presidents to sign reasonable scales for existing union mills only and to refuse to sign for currently non-union mills. ${ }^{64}$ The question of the "labor problem" arose during the very first committee meetings. Some agreed that "a concern operating with a union was pretty badly handicapped," 65 but one member of the committee argued "we will have to recognize the labor unions everywhere sooner or later" because they were "here to stay." unable to agree unanimously on a labor policy, they decided that the "general policy should be to temporize for the next six months or year until we get fully established," and to leave unions at the various plants undisturbed. ${ }^{67}$ This position was stated more explicitly during the June 17 , 1901, meeting of the Executive Committee when they resolved that "we are unalterably opposed to any extension of union labor and advise subsidiary companies to take firm position when these questions come up." 68

It became impossible to "temporize" as the Amalgamated Association sensed that an opportunity to extend its organization existed that would soon vanish. Union leaders were aware that U. S. Steel was still trying to create uniform conditions in its mills and needed to gain the public's approval as they were at risk of being labeled a monopoly. ${ }^{69}$ Workers also believed that with the creation of the corporation managers could no longer afford to suffer through a strike because the price of their stock would fall. The logic was that previously owners personally suffered a short term loss of profit during strikes, but now executives could no longer make this sacrifice since they answered to stockholders. Accordingly, now with many different plants coming under the control of a small group of executives concerned about the public and the stockholders, the union seemed to have an opportunity to organize all the mills that might never come again. ${ }^{70}$ Thus, they acted aggressively.

When negotiations began the wage committee and President T. J. Shaffer demanded that the American Tin Plate Company sign the agreement for all its mills. Once again, the company pointed out that the Monessen mill was unique and could not be included on the same wage scale. The union reiterated that all mills should be included in the agreement. In response, the company promised to sign an agreement for the Monessen plant if the American Sheet Steel Company signed for all its mills. With this verbal proviso, the union conceded, and the agreement was signed on June 21, 1901, after a surprisingly brief conference. ${ }^{71}$ The Association 
made the same offer to the American Sheet Steel and American Steel Hoop companies. ${ }^{72}$ On June 26, the American Sheet Steel Company offered to sign for all the mills on the previous year's scale minus two mills (Saltsburg and Old Meadow) which, the company argued, had abandoned the union. At a second conference on June 29, American Sheet Steel Company representative, Persifor F. Smith, made the same offer. ${ }^{73}$ T. J. Shaffer came out of the conference furious saying that Smith "sat there like a great judge without a jury, and whatever he decreed was law." Since Smith showed no willingness to compromise, Shaffer and the wage committee had no choice. Shaffer announced publicly: "I have preached conservatism and held to it for three years, but in return we get nothing but subjugation and humiliation, and now we revolt.",74

Shaffer ordered the men of the sheet and hoop mills out on strike July, 1, 1901, though only some of the hoop mills in Ohio were organized at the time. The same day, Shaffer sent a letter to Warner Arms, vice-president of the American Tin Plate Company that unless the strike was settled by Monday, July 8, that it would be his "very, very unpleasant duty to call from their work all of your workmen who are members of the Amalgamated Association."75 An estimated 38,000 workers from the sheet and hoop mills answered the call. ${ }^{76}$ The Amalgamated Association had judged U. S. Steel's vulnerability well. Elbert H. Gary, chairman of the Executive Committee, said that it was the "very worst time of the very worst year to have any trouble," and on July 8 the Executive Committee voted to compromise with the union. Shaffer agreed to postpone his deadline until after the conference, which was scheduled for July 11. The Executive Committee planned to settle on the "very best terms possible and as quickly as possible,"77 but the union became convinced of the opposite. Just before the conference, twelve men at the Wellsville plant were discharged for trying to form an Amalgamated lodge leading the union to believe that U. S. Steel intended to break the union because. Shaffer retorted that there would be no conference until the twelve men had been reinstated. ${ }^{78}$

Now the Executive Committee had to decide whether they should direct the subsidiary to reinstate the twelve men. By now, two schools of thought had developed among the committee members as to how to handle the labor problem. One group came from the era of the Homestead strike and had developed an unflinching hatred of unions. "I have always had one rule," said one U. S. steel executive. "If a workman sticks up his head, hit it."79 The president, Charles Schwab, epitomized this group. He started working in a steel mill at the age of 17 and rose through the 
ranks of the Carnegie competition and promotion system. He had little sympathy for the workers and nothing but animosity for unions. For these steelmen, preventing labor troubles meant attacking unions through discharge, espionage, and intimidation. ${ }^{80}$ One such executive asserted in a Committee meeting that "long experience" had taught him that "if certain situations which naturally arise from time to time be not quickly disposed of on the spot with a firm hand, you will then witness the beginning of the end." ${ }^{, 81}$ The second group was comprised of financially minded men like Elbert Gary who believed in earning the loyalty of the workers through fair treatment. They argued that good wages, safe work environments, and other benefits would prevent work stoppages and bring labor and capital closer together. Furthermore, they believed that their philosophy was more honorable unlike the brick-bat tactics of the steelmen. One belief that both schools shared was that, in Gary's words, there was "no necessity for labor unions." 82

Gary felt that the present situation was an example of how the steelmen's philosophy was flawed. He commended the tin plate executives on their "admirable management of their business," and said that if Daniel G. Reid, president of the American Tin Plate Company "had been in charge of the business of the hoop and sheet mills he would have settled this long ago." After much debate Gary's clique won the day, and the committee resolved to reinstate the twelve men who had been discharged in Wellsville and to concede three mills to the union. ${ }^{83}$

When the Amalgamated Association met with company representatives in Pittsburgh on July 11,12 , and 13 , the union continued to demand a contract for all the mills and agreed to make special previsions for the Monessen plant. They also assured the company that if there were to be strikes with independent companies in the future that the Association would not call any sympathy strikes against U. S. Steel. The company offered to sign an agreement that included sheet mills at Scottdale, Saltsburg, McKeesport, and Wellsville. This would have reduced the number of non-union sheet mills to five of twenty-three which would have given the union six more than they had had, but the company only offered to sign for the hoop mills that had been signed for the previous year. Unfortunately, the Association had already decided they must have a company wide contract, and furthermore, some of the non-union hoop mills had been organized during the strike. The union decided that these new lodges could not be abandoned, and the offer was rejected. ${ }^{84}$ 
U. S. Steel now had a very convincing argument to put forth to the public. Executives claimed that they did not refuse the right of the workers to organize, but that there were many men who did not "wish to become association members" and that "they must respect those men in their wishes." The company had offered to concede more mills to the union than previously, but according to company officials, the union was unwilling to compromise. After the conference Secretary-Treasurer John Williams of the union saw the situation entirely differently: "I have always maintained a conservative position in regard to industrial struggles, but the time has now arrived when the Amalgamated Association recognizes that it has a principle to defend. ${ }^{, 85}$ On July 15 , Shaffer called out the tin plate workers, thereby breaking the agreement he had already made with the American Tin Plate Company.

The contest was shaping up to be one of obvious importance to labor everywhere. Pittsburgh District President Patrick Dolan of the United Mine Workers of America pledged the support of the 50,000 or more miners in the Pittsburgh district who were willing to go out on a sympathy strike if the Association so desired. ${ }^{86}$ Samuel Gompers met with T. J. Shaffer and offered him the moral and financial support of the American Federation of Labor. Gompers also offered AFL organizers to be wherever Shaffer needed them, but Shaffer was confident that the union could win the struggle without extra organizers; later, many contended the Amalgamated officials had been "overconfident." 87

Two weeks after Shaffer called the tin plate men out, negotiations resumed in New York City at J. P. Morgan's office on July 27. Shaffer and Williams were impressed with Morgan who told them that essentially he was on their side, but that change must come slowly. Shaffer and Williams signed an agreement with Morgan for the plants that had been on the previous year's contract, which did not even include the four additional plants offered on July 13. Morgan thought the agreement was binding and was outraged when he learned that the union's Executive Board voted it down. ${ }^{88}$ The entire Executive Board then went to New York and proposed to Morgan that the scale include only the mills where the men had gone out on strike, thereby showing a willingness among the workers to belong to the union. This would have included most of the hoop mills, all the tin plate mills except Monessen, and all the sheet mills from the previous year plus Wellsville and McKeesport, but not Saltsburg or Scottdale. Morgan flatly refused. ${ }^{89}$ 
Now the union had nothing to lose. Before the Executive Board left New York City, they instructed Shaffer to call for a general strike against U. S. Steel, which he did. On August 6, Shaffer issued a statement charging that the "United States Steel Trust" had refused to recognize as union men those "who are now striving for the right to organize." He asked that all "Amalgamated and other union men in name and heart" join the fight for labor's rights or "give up forever our personal liberty." He argued that while many of them had signed contracts, they did not agree to surrender them to U. S. Steel whose "officers think you were sold to them just as the mills, contracts and all," Shaffer declared. ${ }^{90}$

Two days later, Shaffer asked Gompers to make the steel strike "the central fight for unionism." 91 Gompers refused, and he, John Mitchell (the national president of the UMWA), and a committee from the National Civic Federation (NCF) began to work toward a settlement of the strike. ${ }^{92}$ The NCF was an organization designed to bring capital and labor closer together. Thus, it was their desire to see an end to the present strike and a return to more peaceful relations. The miners would not come out in a sympathy strike, and Shaffer had no other way to advance the strike.

Nevertheless, the Wheeling district was solid. Of the eight plants between Wellsville and Benwood, all were now organized; the Wellsville plant being organized just after the strike began. In forty-eight hours, two union officials, at the request of the Wellsville workers, chartered a new lodge with forty-four members. ${ }^{93}$ All the other lodges of the Wheeling district had long been established, and there was a great deal of local support for the strikers. Mingo Junction mayor W. J. O'Donnell said, "I am with the Amalgamated Association men in this fight to the end." "94 On August 14, President Shaffer addressed an "immense meeting" of strikers and union sympathizers at the Wheeling Island fairgrounds. Bands played as the Bellaire and Benwood delegations led a parade that started at the Stamm Hotel at 2:30 p.m. and was joined by the Wheeling and Martins Ferry lodges en route to the fair grounds. At each factory, the cheers of the crowds attested to the "popular favor" for the strike. "With us it is a matter of principle, but with the other side it is a matter of dollars and cents," Shaffer told the crowd. "The trust can't run the mills without you. There is not enough skilled labor left to make more millions for these men who have centralized capital." 95 The Ohio Valley Trades and Labor Assembly, a coalition of local trade unions chimed in with their support. The Assembly denounced the Labor 
World, a Pittsburgh newspaper, for attacking Shaffer and declared that the "future existence of organized labor depends on the outcome of this difficulty." "96 By now, between six and eightthousand workers in the Wheeling district were on strike with only about five hundred remaining at work in the Riverside tube plant in Benwood. ${ }^{97}$ The strike was accompanied by "considerable violence," and the "local plants characteristically supplied their full quota" according to one historian. $^{98}$

While the strikers in Wheeling had the public's support, that was not the case everywhere. The call for a general strike alienated many who viewed breaking contracts as dishonorable. The popular magazine The Nation, for example, was highly critical of the union and the general strike order. "Whatever doubts there may have been about the real issue in the steel strike, they were all swept away by President Shaffer's strike order," one of its writers contended. The author criticized the union for trying to "coerce" men into their labor monopoly which would prevent workers from getting employment without first bowing to their organization. He concluded that such a strategy "stabs free labor to the heart and holds a dagger to the throat of property. An insolent union, aiming at a labor monopoly, rises up boldly in the face of capital and says, 'It is one or the other of us now.' To that there can be but one answer."99 By the beginning of September, the strike was in trouble. Shaffer's call for a general strike did not bring enough workers away the rest of the mills to greatly affect the corporation. ${ }^{100}$ The Wellsville plant among several others had been reopened with strikebreakers. The Wellsville mayor, at the request of D. S. Brookman (the manager of the works that had the twelve Amalgamated men discharged in July), made thirty of the strikebreakers deputies. He said that he did so at the request of the officials of the American Sheet Steel Company to protect the company's property and the strikebreakers themselves. ${ }^{101}$ Soon, the men at Wellsville were broken, and the plant was running again.

Gompers and the NCF got the company to agree, on September 4, to sign for all the plants still on strike, but Shaffer refused. ${ }^{102}$ This would have meant a considerable loss, but after the offer U. S. Steel was able to restart two more mills, the Canal Dover and Demmler works. ${ }^{103}$ When Shaffer finally came to U. S. Steel to negotiate on September 14, the corporation offered a three-year agreement for those still on strike, meaning Shaffer had to sign an even worse agreement than that secured by Gompers on September 4. Shaffer issued a circular giving as 
reasons for the failure the demoralizing lies printed in newspapers, the betrayal by Amalgamated men who worked as strikebreakers, and the AFL's abandonment of their cause. "The A. A. still exists, but it must be strengthened," he lamented. ${ }^{104}$

Gompers took offense at Shaffer's remark that the AFL had not given the Amalgamated "one cent" arguing that he had offered full financial support and told Shaffer that he only needed to apply for it. Gompers claimed Shaffer did no such thing and had instead Shaffer had sent his own requests for financial support directly to AFL affiliates. Gompers also criticized him for not accepting the September 4 offer that he, Mitchell, and the NCF had obtained for him which would have allowed the Canal Dover and Demmler mills to remain unionized. Shaffer had also said that Mitchell promised to order a sympathy strike of the miners if U. S. Steel did not accept one offer they had drafted together. Once U. S. Steel had rejected it, Mitchell's promise turned out to be false. Gompers said Shaffer had threatened U. S. Steel with the sympathy strike without any such promise from Mitchell. ${ }^{105}$

In the end, all the finger-pointing and accusations were irrelevant. The final settlement the Amalgamated Association signed was one "from which the union never recovered.",106 Union leaders had miscalculated the corporation's reliance on the skilled workers. One official claimed they lost the strike because of U. S. Steel's “evident willingness to spend millions to teach green labor to become experienced and skilled."107 The union had hoped for a plunge in the stock market and more public interest, but neither of those factors came to fruition. ${ }^{108}$ Because of all these terrible miscalculations, the union lost fifteen plants, and much more. ${ }^{109}$

First, the strike completely depleted their treasury. Second, as part of the settlement, the union agreed not to attempt to extend its organization to any of the U. S. Steel plants that were non-union. ${ }^{110}$ The loss of the 1901 strike also did considerable damage to the morale of the men. One example is the experience of the men in McKeesport. They had been struggling for recognition since 1882. That year a lodge was formed and disbanded the same year. This was repeated in 1886 and 1891. Again in 1900 a lodge was secretly formed at the Dewees Wood plant, but when officials learned of it several were discharged and the lodge was broken. ${ }^{111}$ In July 1901, both the Wood plant and the tube works there made a "last stand" for unionism and were the only mill in Allegheny County to join the strike. ${ }^{112}$ They probably came out because McKeesport was one of the few mill towns where U. S. Steel did not dominate the local 
government. For the workers' participation in the strike, the corporation threatened to dismantle the Wood plant. ${ }^{113}$ The plant was restarted, however, after the strike, and the president of the lodge was blacklisted from every plant of the corporation. ${ }^{114}$

Others who were not blacklisted had to sign ironclads or yellow dog contracts to get their jobs back. One such man had been a strike leader during the 1901 affair and went back to work knowing that the mill would be non-union. He had received letters of encouragement from nationally recognized labor leaders during the strike, but when asked what he had done with the letters he replied: "I burned them when I came back to the mills. . . .When I came back here, I knew I was coming to a non-union mill and I took a job in good faith as a non-union man. That is a chapter in the history of my life that is ended. The whole matter of unionism is a thing of the past, and as an employe in this mill, I have no part in it." ${ }^{115}$ Thus, there was a loss to the union that was not measurable in the terms of the settlement or in the number of plants included.

Michael Tighe, who originally worked for the Wheeling Iron \& Steel Company and later became president of the Amalgamated Association, said that during this period, the union's policy in business relations consisted of "giving way to every request that was made by the company when they insisted upon it." 116 U. S. Steel quietly rid itself of many local lodges by shutting plants down until the workers signed contracts disavowing any connection with any labor organizations. The union was powerless as more and more of the plants fell to this method that was dubbed "starvation and petition." The last of the basic steel mill charters was surrendered in 1903. ${ }^{117}$ Also, the Monessen system of tin plate production was extended to other plants during this time, which according to the workers, "involves a heavy reduction of wages, reduces the number of highly skilled rollers by one-half, increases the number of men at work and increases the tonnage." 118 Another blow to the union came in 1904 when they were forced to drop all production restrictions from the footnotes of the wage scale agreement. Also, in 1904, the two subsidiaries, the American Tin Plate Company and American Sheet Steel Company, merged to form the American Sheet and Tin Plate Company bringing them under one management headed by the president of the sheet steel company. Lastly, the tube works all became non-union plants in 1907 and 1908. ${ }^{119}$

The situation only became worse for the union, which became an increasingly exclusive organization of the highly skilled and highly paid. The remaining puddlers, frustrated by the lack 
of concern that the union leaders (now mostly from the ranks of the finishers in steel mills) paid to them, withdrew from the Amalgamated in 1907 and reformed the Sons of Vulcan. ${ }^{120}$ In 1907 , a business depression called the "Banker's Panic" dealt a blow to the steel industry, and workers suffered an extended period of idleness. In 1908, Walter Larkins of the AAISTW took a tour of various mills and found several of them idle as the industry was still feeling the effects of the depression. "Where is the full dinner pail," he asked. ${ }^{121}$

Through these years, Elbert Gary and Charles Schwab continued to struggle for control of the Executive Committee. Eventually Gary won out and brought independent producers to dinners where techniques of cooperation on "fair competition" were ironed out. After the antitrust suit, they were no longer permitted to establish such explicit agreements. Independents still followed the lead of U.S. Steel, and the decades of fierce competition between the steel companies came to an end. ${ }^{122}$

During the years after the strike, the union nevertheless remained strong in a few districts like New Castle, Elwood, and Wheeling. The Mingo Junction men refused to agree to the 1901 settlement at first, and within a few years their local lodge had disbanded. Likewise, the lodge at the sheet bar mill in Bellaire owned by National Steel had been strong in 1901, but it too soon fell. The Wellsville and Chester lodges did not survive the strike, and the Benwood lodge of the Riverside works was gone by 1908, when the union was driven from the last of the National Tube Company's plants. ${ }^{123}$ Despite these losses, all the independents and the three sheet and tin plate mills of U. S. Steel were still organized. Additionally, unlike several other districts, not a single plant was dismantled in the Wheeling district, and, in fact, the Laughlin plant was expanded to become one of the most modern tin plate plants in the world. ${ }^{124}$

Compared with other districts, Wheeling's lodges had been successful until 1902. Between 1891 and 1902, the number of lodges in the Pittsburgh district dropped from 94 to 30, and the Youngstown district had dropped from 53 to 41. The number of lodges in Wheeling increased from 18 in 1891 to 19 in $1902 .{ }^{125}$ Still, the Wheeling district felt the losses between 1902 and 1908, as the number of lodges dropped from 18 to about 6 , but this was still better than most of the districts around the country as the open shop movement spread.

While the Wheeling district remained relatively unionized, morale in the district did not remain uniformly high. Early in 1909 , union men complained that there were too many who did 
not take enough interest in their organization "by not attending meetings of the lodge that helps make their scale and conditions in the mill which many receive and enjoy," according to one in Martins Ferry. Furthermore, he complained that too many were delinquent in their dues: "The man who does not pay his part of the expenses ought to be ashamed of himself, and quit the job and let some fellow have the job that is willing to help pay."126 "Some get sore because they get dropped from membership for not paying their dues," he wrote from Martins Ferry. "Now I'd like these same people that are dropped [to] tell us how we are going to carry on the business without money." 127 Still, the 1909 open shop announcement came as a great shock to them because their lodges had survived the worst assault. 


\section{Chapter Three: The 1909-1910 Strike}

The open shop announcement came on June 1, 1909, just a month after the convention of the Amalgamated Association of Iron, Steel, and Tin Workers. There was no hint of trouble at the convention, and the union drafted a wage scale with few changes from the year before. Emerging from the 1907 economic downturn, workers and management alike were relieved to have abundant orders, and the mills were running at full capacity with a few exceptions. Wheeling's business community concurred saying that it was "especially gratifying that the complete recovery of the iron and steel trade which now seems to be so near at hand is not likely to be interfered with or delayed by any possible labor difficulties." ${ }^{1}$ As there had been little change in labor relations for a few years, it did not seem as though there would be any in 1909, but the announcement changed everything. ${ }^{2}$

It is unclear why U. S. Steel chose this time to force the last of its union plants to work on an open shop basis. Perhaps the decision was a response to the increased competition the sheet and tin plate division had faced during the previous few years.. When U. S. Steel was formed in 1901, it controlled the vast majority of the country's sheet and tin plate capacity, but competition had been increasing ever since. ${ }^{3}$ This was probably because it only required about $\$ 500,000$ to start such a finishing plant whereas a company needed $\$ 20,000,000$ to build a competitive basic steel mill. ${ }^{4}$ It is just as likely, however, that U. S. Steel merely did not want to have to deal with the restrictions and complications that came with a union workforce.

The reactions to the open shop announcement were predictable. Wheeling's business community hoped the workers would acquiesce and continue to work warning that if they did not the company would fill orders from other plants where the open shop was in effect. ${ }^{5}$ Throughout the strike, the Wheeling Intelligencer continued to express the hope that the mills would resume regardless of who won the strike, and to remind strikers that their struggle was futile. ${ }^{6}$ Elbert $\mathrm{H}$. Gary, chairman of the Executive Committee of U. S. Steel, announced on June 4 that the "management of the American Sheet \& Tin Plate Company has discovered it has been discriminated against and in other ways unfairly treated by the Amalgamated Association. The management also discovered beyond question that a very decided majority of the men prefer to have all mills operated on an open shop basis."7 Meanwhile the union argued that "to accept the 
corporation's mandate is to become its slaves, to be hounded by the corporation's merciless managers that they may make records for themselves."

On June 7, the advisory board of the union met in Pittsburgh. Vice-presidents Walter Larkins and Llewellyn Lewis, of the advisory board, lived and worked in the Wheeling district. Lewis was the vice-president of the sheet division, and Larkins was the vice-president of the tin division. The advisory board decided that a meeting of all delegates should be arranged at once and that lodge elections should be held as soon as possible to select the delegates. ${ }^{9}$ All of the lodges held meetings to discuss the situation and elect delegates for the convention that would decide the matter. The delegate convention met in Pittsburgh on June 14 and decided that the "only thing the Association could do under the present attitude of the corporation would be to resist its non-union policy and refuse to work after June 30, 1909." ${ }^{10}$ In Martins Ferry, closed meetings of the Mountain City and Lewis Avon lodges were being held at the Lyric Theatre. Treasurer John Williams addressed the two overflowing meetings, while across the river in Wheeling, Assistant Secretary Michael Tighe talked to the men of Prosperity lodge. Williams spoke to the men for half an hour and then fielded questions from the audience. One worker claimed it to be the "best talk ever delivered to a meeting of mill men in this vicinity," adding that if "any brother came to that meeting with the intention of going to work, or a doubt in his mind, it surely must have been cleared." 11 Meanwhile, company managers had been calling workers individually into their offices and trying to intimidate them into coming to work. Despite these efforts, the workers felt confident that "when July $1^{\text {st }}$ comes around we expect to have them lined up in one compact body; that not a man will disobey the orders of the executive board." 12

As predicted, the union mills followed the executive board's order. At the time about sixty percent of the tin division was organized. ${ }^{13}$ Many of the men at the Laughlin and AetnaStandard plant refused to even come to work on June 30, and the next day the plants were completely shut down. The local newspaper, however, claimed these two plants shut down early due to heat. In the rest of the tin plate division, the plants in Elwood, two plants in New Castle, Sharon, and Wheeling were shut down on July $1 .{ }^{14}$ These were by far the largest tin plate mills in operation, and their closure seriously hindered U. S. Steel's tin plate business. Other union tin plate mills were inconsequential such as the ones at Piqua, Ohio, Connellsville, Pennsylvania, 
Baltimore, Maryland, and Gas City, Indiana. They had been idle so long that the company apparently did not intend to start them up anyway, and the Gas City lodges charter had even been surrendered by this time. Thus, the fight in tin plate was primarily in Elwood, New Castle, Sharon, and the Wheeling district. ${ }^{15}$

Sheet steel was a different story as most of the sheet mills were non-union and had been since the 1901 strike. Only about thiry-five percent of that division was still unionized. ${ }^{16}$ The plants at Leechburg, Hyde Park, Saltsburg, Canal Dover, New Philadelphia, Midland, Old Meadow, Scottdale, McKeesport, and Wellsville, all with eleven or fewer mills, were non-union and continued operating after the July 1 strike date. The enormous Vandergrift works with thirty-seven mills, more than twice that of any other plant, was also non-union and continue running. ${ }^{17}$

The thrity-five percent of the sheet mills that had remained unionized did shut down with the exception of the the Guernsey plant in Cambridge, Ohio. J. A. Bowers, secretary of the insurance department of the Amalgamated Association, said that the "condition at the Cambridge plant is the result of the same tactics employed several years ago when the Steel Corporation by keeping the mills idle for a considerable time, compelled men to ask for work, the Amalgamated practically being forced to give up the mills at New Kensington, Dresden, O., and Canton, O.” Bowers continued: "These have been the methods employed ever since the American Sheet and Tin Plate Company was formed. They were used by the Apollo Iron and Steel Company in the summer of 1893 , when the plant there, after the scale had been signed, was shut down on July 24 and kept closed until October 6, when the mill was started up again and the men asked to report to work individually." Bowers pointed out that George G. McMurtry was the president of the Apollo Iron and Steel Company and later the first president of the American Sheet and Tin Plate Company. "Some of the present officials of the company, who were understudies of Mr. McMurtry," Bowers concluded, "appear to be continuing this feature of his policies."18

For every union man that went out about one unskilled, non-union worker was affected. The LaBelle tin plate mill, for example, employed about 500, and all came out even though only about half were union members. In all, about 5,000 union men were on strike out of a company that normally employs 25,000. ${ }^{19}$ Plus the Tin Plate Workers International Protective Association had about 3,000 members, but it was yet to be seen whether or not they would join the hot mill 
men in the strike when their contract expired. If the Amalgamated Association could win a victory in this contest, as the logic went, then perhaps the rest of the workers in the steel industry in general would put their faith back in the union. The Association's president, P. J. McArdle, announced that he did not "fear the outcome of the strike" and that they fully expected to win. Secretary John Williams concurred: "We are going to make an aggressive fight. We have not been given an opportunity to confer with any of the corporation officials and intend now to stick it out until we get what we want." ${ }^{20}$ The union knew the importance of the strike, and the Amalgamated Journal declared that the "supreme test in the sheet and tin trades is at hand."21 They knew that a loss would not only mean the end of the union at U. S. Steel but also that it would bring further losses as independents followed the corporation's lead.

Some independents had already refused to sign the Amalgamated wage scale. An official of the Youngstown Sheet \& Tube Company summarized his company's position clearly: “We have always signed the Amalgamated scale, ever since we have been in business, but we shall do so no more. The American Sheet \& Tin Plate Co. has decided to get along without the Amalgamated scales, and we must also. The time was when the Amalgamated set the wage, but now the Corporation is doing it." 22 Another company to refuse to sign the scale was the independent LaBelle company that still owned the nail works in Wheeling and the blast furnaces of the Jefferson works in Steubenville. The workers in Steubenville had remained organized until U. S. Steel broke with the Amalgamated Association, and the LaBelle Company refused to sign a contract with them. The strikers in Steubenville and the other employees of independent companies felt that they were fighting the same battle as the employees of U.S. Steel, and the two groups considered themselves to be one. In fact, many union members wanted the union leadership to call all of the Amalgamated men out on strike because they believed that since U. S. Steel set the standards for the whole industry that there was no difference between the corporation and the independents. ${ }^{23}$

Both U. S. Steel and the Amalgamated Association adopted aggressive strategies. For U. S. Steel that meant reopening mills that were on strike, and for the union that meant getting nonunion plants to join the struggle. The American Sheet and Tin Plate Company announced that it would start up the Monongahela plant in Pittsburgh's South Side and the United States plant at Demmler, both of which had been idle for some time. The company was confident that it had 
enough "independent" labor to find the 1,200 men required to run these two mills. ${ }^{24}$ The union had been prohibited under all agreements after 1901 from trying to extend its organization to other U. S. Steel plants, but the company's open shop announcement "opened the way for a general attack on all of its plants by Amalgamated men," according to Secretary John Williams. "We were held in check more or less in the past because we did not want to injure our standing with the sheet and tin plate departments by pushing our organization in other unorganized mills." 25 Now they hoped to organize all of U. S. Steel.

First, the union set their sites on the plants at Vandergrift and Apollo, Pennsylvania, two tradtionally non-union plants located on the Kiskiminetas River separated by only two miles. The Kiskiminetas Valley was also home to the sheet works at Leechburg, Hyde Park, and Avonmore. Vandergrift had long been considered a company town, and union leaders knew that if organizers could get workers there to join their fight, it would be the union's greatest accomplishment of the union of the last twenty years. To induce the workers there to go on strike would not only shut down the corporation's largest sheet mill, but it would be a powerful, symbolic victory over the company. It would not be easy to accomplish this, however, as the Vandergrift workers had shown an unwillingness to join the union and had gone so far as to support the company in the 1901 strike. $^{26}$

Vice-president Llewellyn Lewis, of Martins Ferry, was chosen to be one of the organizers to do the job. Little is known of Llewellyn, but his brother, Thomas L. Lewis, was president of the UMWA at the time. ${ }^{27}$ Tom was born at Locust Gap, Pennsylvania in 1865, and the Lewis family moved to Shawnee, Ohio, shortly after it was laid out. In 1882, Tom joined the Knights of Labor and rose to prominence in the 1884-5 Hocking Valley miners strike when he became very active in trade unions. Tom moved to Bridgeport, Ohio, in 1889, was elected a delegate to the 1890 convention, which created the UMWA out of rival organizations, and became a vicepresident of that organization in $1900 .{ }^{28}$ Llewellyn was living just up the river from Tom in Martins Ferry at the time of the 1909-1910 strike. He had been an organizer as early as $1903,{ }^{29}$ was active in the OVTLA from that time as well, and had been president of the Ohio Federation of Labor in 1908. He obviously had a strong background in trade unions which was probably the reason he was sent to Vandergrift at the start of the strike. 
George Evans, George Bender, and William Hilton, other union organizers, arrived at Vandergrift July 1, when Lewis left to go to Pittsburgh to attend to union business while the others began the work of organizing. On Friday, July 9, Lewis returned to Vandergrift on the train where he met A. Jenkins and Forny James, organizers from the UMWA that were going to talk to miners in that area. Jenkins and James invited Lewis to join them as they knew some of the men working in the mills. About noon, the three men arrived and began inquiring about people working in the mill, and they were told to go to Vandergrift Heights. They went there at once and found the men "anxious to organize."30

After talking to the men of the mills, the organizers were told to return at 6:30 p. m. when they would be given a list of names. When Bender, Hilton, Evans, and Lewis returned they found that the men to whom they had talked earlier had been threatened with discharge and everyone was "uneasy." The four organizers left the Heights to return to Vandergrift, and a mob, led by Labanna Steele and a Mr. Dunn, both watchmen for the company, were waiting. Lewis later said, "I tried to point out to them that we were there for the purpose of discussing the question of organization, when I was struck alongside the head with a broom handle in the hands of Mr. Steele, Mr. Dunn smashing my glasses at the same time." The mob then descended on the four organizers and began assaulting them. One man struck at Hilton with a knife. Then the organizers were taken to the depot and put on a train "with a warning never to return." Thus, their first effort was a total failure. During their time there, they could not even rent a hall for a meeting because property owners were afraid the American Sheet \& Tin Plate Company would make it "so unpleasant" for them that they would "be compelled to leave the community.",31

Robert Edwards, of Martins Ferry, another organizer for the Amalgamated Association, remained in Vandergrift and began distributing circulars to the mill men. On July 22, Jack McIntyre, a foreman in the galvanizing department at the Vandergrift works, approached Edwards and asked him what his business was. McIntyre told Edwards that he "was not wanted in that locality" and instructed him to leave town on the next train. Edwards found himself surrounded by company men and so he began to head toward the depot. He slipped into the post office for refuge, but when he came out McIntyre again told him again to get on the next train and that if he returned to Vandergrift he would "be taken out in a box." Edwards went to the neighboring town of Apollo and somehow managed to rent a vacant lot. He scheduled to have a 
meeting on July 31, 1909, but when the lot owner found out that he intended to hold a union meeting he asked Edwards to return the receipt and he would return his money. The property owner said that if he "permitted the property to be used for a labor meeting that his business interests in the community would be ruined." Edwards refused and asked John Kennedy, the Apollo chief of police, for protection during the meeting. Kennedy agreed but told Edwards to be "prepared for trouble.", 32

On July 27, four days before the meeting in Apollo, the Vandergrift city council passed an ordinance prohibiting the "posting or passing of handbills, circulars, samples, printed or written matter of any kind" without the permission of the burgess. Violators were made subject to a maximum fine of $\$ 5$ and a maximum jail term of 30 days. ${ }^{33}$ There could be little doubt that the law was directed at the Amalgamated organizers. It was for this reason that the meeting was held in Apollo, where the company exerted less influence, albeit only a slight degree less.

Llewellyn Lewis presided over the meeting, and Raymond Robins of Chicago spoke. Lewis later said that it was the first union meeting held in Apollo in fifteen years. ${ }^{34}$ There was no trouble at the meeting, and the police chief even ejected one company man who tried to start trouble. After Edwards and other organizers had returned to the Parks Hotel in Apollo where they were registered, Oscar Lindquist, the superintendent of the Vandergrift plant called on them. He asked them what their business in town was, and when they told him they were representatives of the union, he said they would simply have to leave. The organizers replied that they were "exercising their rights as American citizens as guaranteed to them by law." Superintendent Lindquist replied that "his word was the law;" he was "the Scottish chief in that valley," and "what he said must go." He told them they had one hour to leave town and that he would get them out "if he had to burn the hotel down." Meanwhile a crowd of about 200 people had gathered outside and stayed there until around midnight. Then the burgess of Apollo approached the organizers and told them he could no longer control the crowd claiming that he had promised the crowd that he would make sure the organizers left town on the first train in the morning. If they did not, he said, there would be no way to "avert bloodshed." Thus, the organizers left having failed to organize the men yet again. ${ }^{35}$

U. S. Steel's control of Vandergrift was complete. Originally it had been designed to be a model industrial town. The visionary behind the design, George McMurtry, had wanted to make 
a community "something better than the best," and created one whose focal point was the Apollo Iron and Steel Company. ${ }^{36}$ McMurtry became involved in the iron and steel industry in 1883 when he joined Jacob J. Vandergrift and seven other investors in a company called the Volta Iron Company. They purchased a galvanizing plant in Pittsburgh and an iron mill in Apollo, and in 1886, the company changed its name to the Apollo Iron and Steel Company. In the spring of 1893, less than a year after the 1892 Homestead strike, McMurtry and the company, faced with a serious decline in business, negotiated a wage reduction with the Amalgamated Association. The rollers at Apollo refused to abide by the new scale and walked off the job in August. Just as J. A. Bowers told reporters at the start of the 1909-1910 strike, McMurtry shut the works down until October and declared that he would only accept workers who renounced their union membership. Only three of the rollers went back to work, and McMurtry began recruiting and training workers from the countryside and mines. Early in 1894 with the strike still on, union members realized that McMurtry would not tire of "trying to make rollers and heaters out of civil engineers, railroad firemen, and farmers." 37 They left for other mills, and the Apollo works stayed nonunion. McMurtry sought to find a solution to the gap between labor and capital hoping to avoid such unpleasant struggles in the future. ${ }^{38}$

For McMurtry, the solution was the model town. He visited European model industrial towns like the Krupp estates near Essen, Germany, and brought the ideas back to Apollo. Andrew Carnegie had done something similar when he laid out the town of Munhall offering low-interest home loans through the company after the Homestead strike. Like Carnegie, McMurtry knew that home ownership tied the worker to the community and made him less likely to risk his employment there. McMurtry went a step further, having the idea that good housing and a good living environment would make good people, which, in turn, would make good workers. He purchased a 640 acre farm one mile down river from Apollo on which to build the town of Vandergrift. He hired the well-known Boston landscape firm of Frederick Law Olmsted, Sr. to design the town, and construction of the immense sheet steel plant began there in 1896. McMurtry, J. J. Vandergrift, and several other investors formed the Vandergrift Land and Improvement Company (VL\&IC) and designed lots to be affordable while still targeting the highly skilled (and highly paid) workers that would work in the sheet mill. Additionally, workers who had been loyal to the company were given the first opportunity to buy the lots. Their plan 
came to fruition when a large percentage of the skilled workers bought lots and became home owners. The VL\&IC used the same scheme when they purchased Vandergrift Heights, and again workers purchased lots and began building homes. A third neighborhood called Morning Sun became the home of the Eastern and Southern Europeans that worked in the mill Being unskilled and low paid, they mostly rented. McMurtry's plan to promote home ownership among the workers had a profound effect on the labor struggles that were to take place in the coming years. $^{39}$

By 1897, the new, integrated Vandergrift plant was producing 70,000 gross tons of ingots, 96,000 gross tons of sheet bars, 38,000 tons of black sheets, and 51,000 tons of galvanized sheets. ${ }^{40}$ The Apollo Iron and Steel Company sold the old mill in Apollo to the American Tin Plate Company early in 1899, and, shortly thereafter, sold the new "state-of-theart" steel works to the American Sheet Steel Company. McMurtry gained a considerable reputation among the businessmen of the industry because the Vandergrift works produced onefifth of all U. S. sheet steel. This stature helped him become the first president of the American Sheet Steel Company and, later, the first president of the American Sheet and Tin Plate Company. ${ }^{41}$ From this vantage point he watched his vision of close ties developing between labor and capital come to fruition.

McMurtry's representative, Pursifor Smith, managed the negotiations with T. J. Shaffer that resulted in the 1901 strike. The union leaders set their sights on Vandergrift in 1901, much as they would eight years later, because of its size and reputation as a non-union stronghold. Before they could begin organizing, a standing room only meeting of company supporters was held, and one worker after another as well as many local businessmen professed their loyalty to the company. One speaker at the meeting took pride in the fact that they had "an entire moral and modern industrial town, to which hundreds are journeying every year in search of steady employment and good wages," and said that he had "never received better treatment anywhere." 42 Thus, McMurtry had instilled a sense of loyalty to the company among at least some of the workers. Others, even though they did not say so publicly, had more practical concerns. One anonymous writer to the Amalgamated Journal charged that those "poor fellows are so bound up by their property investments that they are afraid to make a move publicly in favor of organization, but the union sentiment is gaining ground even in Godforsaken 
Vandergrift, and those poor slaves will yet be prevailed upon to make an attempt to remove the shackles which bind and make them to all intents and purposes greater slaves than were the colored men of the south before the war."43 Another anonymous writer said that the company had the "spy system" and had "worked up the spirit of distrust among the men to an extent that scarcely seems possible to one not acquainted in this town." He insisted that they had nothing to lose if they all came out but that anything less would allow the company to continue. If that happened, all that left work would lose not only their job but also their house if they had a mortgage. $^{44}$

Either because of a feeling of loyalty to the company or out of fear of discharge the workers at Vandergrift did not quit work for a single day during the 1901 strike. In fact, McMurtry began moving skilled workers to Hyde Park and Wellsville to train strikebreakers. ${ }^{45}$ After the strike failed, the industry publication Iron Age proclaimed McMurtry's vision a success: "His creation of a model industrial town, peopled by men untrammeled by affiliations with labor union, has, however, now brought to him the crowning vindication. His men have stood by him, and the principle of frank and cordial relations between employer and employed." 46 The other executives at U. S. Steel were so impressed that they tried to replicate the Vandergrift model at Gary, Indiana, around the enormous plant they built there in $1906{ }^{47}$ Therefore, organizers sent to Vandergrift in 1909 had more to contend with than local ordinances and a few company bulls. McMurtry's scheme had created a whole environment hostile to unions. The loyal workers were more than willing to gather into an angry mob and oust the organizers. Despite this, Llewellyn Lewis remained optimistic claiming to have a plan by which they would "secure better treatment in the towns and cities where we are trying to organize the non-union men." ${ }^{48}$ He enlisted about 150 men from Martins Ferry and planned for them to parade through the streets of Vandergrift on Labor Day. With such a large group, company officials could no longer claim a few outside agitators were trying to disturb the harmony of the people. ${ }^{49}$ Burgess James Chambers refused to allow such an event to take place and, on August 31, issued a proclamation stating that the people of Vandergrift "deplore" anything that would "mar the peace and harmony" of the town. Since "outside influences seem to be at work," he outlawed parades, marches, meetings, and the "assembling of persons in large 
crowds upon the streets, alleys, highways, or private properties." This, he believed, would prevent the non-residents from engendering "ill feeling among our citizens and neighbors.",50

One reporter noted that Labor Day in Western Pennsylvania presented a "unique and grim anomaly." About 5,000 steelworkers plus 5,000 glass workers and 18,000 miners were either out on strike or locked out "making the day set apart for the working man, one to be remembered in labor circles for years to come." To add further irony, he observed that Chambers had "issued a proclamation to the effect that Labor day cannot be celebrated in his domain tomorrow." 51 The Intelligencer predicted that the "proclamation, although against the constitution of the United States, will be enforced in Vandergrift, as the mayor is backed by an element that does not recognize Labor day as a national holiday." Either wanting to avoid a riot or incarceration, the parade of the Martins Ferry men set to go through Vandergrift was postponed indefinitely. ${ }^{52}$

Meanwhile, on the other side of the struggle, U. S. Steel was trying to reopen its mills. As skilled men were required, executives had to look to the existing labor pool, most of whom were on strike. They hired agents to go to the various mill towns to try to induce skilled men away from the picket lines to go to places like Elwood, Indiana, to live in the plant and roll sheet steel and tin plate for daily wages. Such agents would, of course, incur some risk as tensions were high and the strikers constantly on the lookout for trouble from the company. Thus, it took a "special breed" to walk into a town and offer to take men away from the union. These agents were usually men that sought out trouble and were themselves troublemakers. ${ }^{53}$ On July 9, only eight days after the strike had begun, one such agent, William D. Eagan, arrived in Wheeling and began the work of hiring mill men.

Eagan lived in New Castle, but was hired in Pittsburgh at the Frick Building on July 8. The American Sheet and Tin Plate Company employed him, he said, to "assist in getting men to work in their plants and go and obey their orders, wherever they sent them." 54 In his words, he had "rolled from coast to coast," was a police officer at one time, and even played baseball. ${ }^{55} \mathrm{He}$ had lived in Wheeling for three years and Benwood for one, but originally he was from Kentucky. Eagan had been arrested a few times. He had a "checkered past" and was willing to admit it. ${ }^{56}$ When asked about one questionable incident in his past he responded: "All men are guilty, but they don't all get caught., ${ }^{, 57}$ 
Eagan later claimed that as soon as he got off the train he was followed by a man named "Sugar" Wiedman. ${ }^{58}$ The next morning he went to see James Medill, superintendent of the LaBelle plant, and as soon as they left the plant a crowd of people that surrounded them. They had a constable with them who arrested Eagan for possession of a gun, which had been recently outlawed by West Virginia's Johnson Pistol Toting law. ${ }^{59}$ The crowd followed Eagan who was taken down to Justice of the Peace Engel. Frank Bowman, one of the local strike leaders, was there to argue the case against Eagan, and asked Engel for time to bring one of the witnesses to the office. Engel rescheduled the trial for about 6:00 p.m. that night. The men dispersed to the bars where a great deal of excitement arose surrounding the case. The strikers made such boasts as "We've got that big bastard now," and "We'll get Bad Bill tonight." When the hour for the trial came, a large crowd had gathered to watch.

Squire Engel fined Eagan, and Superintendent Medill paid the fine. When Eagan got out on the street, a crowd of about 200 people was waiting. It was not just a crowd of strikers, but included townspeople and mill workers from the independent Whitaker-Glessner plant. As Eagan began to walk up the street, several men quickly converged on him. Someone tripped Eagan, and the mob began to beat him. One man opened up a gash on Eagan's face with a pair of brass knuckles while another man tore a paling off a picket fence and began beating him with it. Eventually Eagan was able to make it to his feet and ran into a house. A woman, there with her children, agreed to let Eagan wash his face in the kitchen while the angry mob waited outside.

After a short time, a paddy wagon arrived at the woman's house to take Eagan to a safe place. That safe place turned out to be the city jail where Eagan spent three days without being charged with any crime other than carrying a pistol for which he had already been fined. When he was released, Eagan met his wife and son at the depot, and he went straight to a hospital in Pittsburgh's South Side. Rumors began to circulate that he was dead, but, as it turned out, after he spent a few days in the hospital he had recovered sufficiently to sign an affidavit that had been prepared for him by a company lawyer. ${ }^{60}$ It outlined the events of the evening of July 10 and was submitted to U. S. District Court Judge Alston G. Dayton. Dayton, after reading the affidavits of Eagan, Medill, and several others, issued an injunction against the strikers on July 21. The injunction forbade several specific strikers named by the superintendent in his affidavit, including Frank Bowman, as well as their "associates and confederates" from "interfering in any 
manner whatsoever with the employees" of the American Sheet and Tin Plate Company and with its property. It also prohibited the placing of pickets or watchmen near the LaBelle works and included a myriad of other stipulations. ${ }^{61}$

Injunctions had become a convenient way for companies to legitimize the use of force to protect their property and the non-union workers they brought in to restart the mills. Dayton became infamous for granting injunctions that were damaging to labor's ability to conduct strikes and picket mills and mines. He had issued an injunction against striking electrical linemen in 1907 preventing them from distributing circulars that publicized their strike and called for a boycott. Later, he issued another one against miners striking against the Colliers Mine in Brooke County in 1913 and 1914 prohibiting them from interfering with the mine in any way. The latter injunction led the Wheeling Majority, the local labor newspaper, to insist that the "people need a judge who will be moved by their suffering, whose eyes are not shut to injustices that beat upon them, whose ears will not be closed to their cries of pain." ${ }^{\prime 2}$ An investigation of Dayton's questionable actions against labor between 1907 and 1913 began in early 1914. In March 1914, the Judiciary Committee of the U. S. House of Representatives began hearings into Dayton's judicial behavior, and when the findings were published a year later the committee found Dayton guilty of "bad taste" and a poor standard of ethics but not guilty of an impeachable offense. ${ }^{63}$

After Dayton issued the injunction against the LaBelle workers the Amalgamated Journal denounced it as hypocrisy: "The American Sheet and Tin Plate Company asks and receives federal and state aid in the form of federal injunctions on the mere supposition that their property is in danger; and yet its managers and hirelings are allowed unmolested to lead mobs against men, simply because in a lawful way they appeal to their workmen to join the movement now on to oppose the establishment of the "OPEN SHOP' (NON-UNION) policy in all its mills."64 There was a growing feeling that courts had usurped power through the use of injunctions that they were not intended to have. Even the rather conservative Wheeling Intelligencer applauded an Elwood judge for refusing to grant the company an injunction against the employees there saying that "except in extreme cases in which federal interests are involved, the federal courts should not interfere in local difficulties." The editor was not entirely sympathetic to the strikers' cause adding that the responsibility for the protection of property "rests properly upon the states." 65 A trial was held the next April to determine if the injunction against the LaBelle 
strikers should be made permanent, but A. G. Dayton reserved his judgment "until a future date." 66 No future action seems to have been taken in regards to the injunction.

After Eagan was beaten on July 10, West Virginia Governor William E. Glasscock read in the Pittsburgh Dispatch that there had been "some trouble" in Wheeling and wrote to Commissioner I. V. Barton to find out if it was serious. ${ }^{67}$ Barton replied that there were "no disturbances" among the strikers and that U. S. Steel was making no attempt to bring non-union workers in to restart the mill. He told the governor not to pay attention to the newspaper accounts as they were misleading. Barton reassured the governor that he had been in the strike district continuously and that he was giving it all of his attention. In conclusion he said: "Everything in the industrial world is progressing nicely."

Eagan was not the only such agent for the company nor was he the only one mobbed by angry mill workers. On July 29, two men were beaten in Clarksburg for trying to induce men away from the Phillips Sheet \& Tin Plate Company, an independent company. ${ }^{69}$ Charles H. Patterson went to Clarksburg offering $\$ 10$ a day to rollers to come to work at the Shenango plant in New Castle. Two employees of the Phillips company talked to him to find out as much as they could. He offered them permanent jobs and told them that the trust would put all the independents out of business soon. They should, he advised them, "come in out of the rain" before their company goes out of business. Then they would be in good standing with the trust and would probably get promotions as they expanded their operations in Gary, Indiana. The agent also assured them protection as he weighed nearly three hundred pounds and was "not afraid of a thousand men." The two men left him and later saw him being chased by a crowd of fifty to seventy men. ${ }^{70}$

July 15, 1909, marked the end of the Tin Plate Workers International Protective Association's contract, and they too came out on strike. The locations most affected were Chester, West Virginia, New Kensington, Pennsylvania, and the United States plant in Demmler. These were the plants where the Amalgamated Associations did not have lodges. Thus, without tin house workers the operations in those plants were "crippled. ${ }^{71}$ It is likely that the other tin houses where the Amalgamated men were out would have been shut down after the supply of rolled sheet and plate was exhausted anyway, but at Chester and New Kensington, only the tin house workers were organized. Thus, two plants that would have been untouched by the strike 
were it not for the TPWIPA lodges. The exodus of the tin house workers reaped some benefits for the Amalgamated Association. J. A. Bowers, the Insurance Secretary, held a meeting in New Kensington on July 17 with 400 in attendance. The hot mill men voted to form a new lodge, and it was named "Conqueror." This was the first time since 1901 that the Amalgamated had drawn non-union workers from an open shop. ${ }^{72}$

The superintendent of the Chester works, George D. Evans, said he did not believe there would be a problem replacing the workers and that the company only "sought to control its own business."73 The mayor swore in four new deputies to help maintain order though the strikers there assured reporters they would only use moral persuasion to try to convince those that remained working to leave their posts. ${ }^{74}$ On July 19, two carloads of about sixty men arrived from Pittsburgh to keep the mill running, which they were able to do for the most part. Evans said he was "well satisfied with the present situation."75

In all, about 3,000 tin house workers, a third of whom were women, went on strike affecting, in addition to Chester, New Kensington, and Demmler, both the Shenango and Greer plants in New Castle, plants in Elwood, Sharon, and the three plants in the Wheeling district. The New Castle tin houses were evidently not organized before the strike, and formed TPWIPA lodges when they came out. In Sharon, forty women left the plant even though they were not union members simply because they "would not handle the product of non-union men."76 In all, 90 percent of the TPWIPA membership was involved in the strike. ${ }^{77}$ Their support helped solidify the efforts of the Amalgamated Association but did not really have that great of an impact on the strike, and the two sides remained stalemated.

In August, I. V. Barton, the Commissioner of Labor of West Virginia, and representatives of the labor departments of Ohio and Indiana came together with the hope of finding a way to bring the strike to an end. They first took the matter to Seth Low, the president of the National Civic Federation. Low presented the matter to Elbert Gary who said that he would not interfere as it was a matter of the American Sheet and Tin Plate Company and its current president, Eugene W. Pargny. Barton and the other state labor agents met with Pargny in Pittsburgh on August 31. Barton reported that Pargny "informed us, in a very decided way, that the company he represented would not consider any proposition of the State Departments of Labor looking 
toward a settlement between themselves and their employees. So our hopes were blasted; there being no other tribunal to which we could apply."

It was obvious to the union that in order to induce the workers in the non-union plants to join them that they would need help, especially since they had decided to take on the responsibility of organizing all of U. S. Steel. The Amalgamated Association simply did not possess the wherewithal to reach the hundreds of thousands of steelworkers across the county. ${ }^{79}$ On June 18, 1909, before the strike, shortly after the advisory board of the Association met in Pittsburgh, President P. J. McArdle met with Samuel Gompers. McArdle told Gompers that his union simply could not yield to the open shop order and that, while he realized the AFL could not provide much financial support at that time, he was hoping that Gompers could lend him the services of a number of the AFL organizers. Gompers told McArdle that "it would be the desire of the A. F. of L. to help him with organizers to the fullest extent of our ability." Gompers wrote to AFL Secretary Frank Morrison that this strike might "be the turn of the tide" and "the men of that industry may again take their position in the front rank of the organized labor movement." 80

McArdle and Secretary Williams sent a letter to a variety of different unions addressed to “ALL MEMBERS OF ORGANIZED LABOR" asking for assistance to combat U. S. Steel's "war of extermination" against the Association. They explained that their limited resources were making it difficult to carry on their organization work and that they did not hesitate to ask for financial support knowing that the contest meant so much to organized labor everywhere. ${ }^{81}$ Unions and labor organizations all over the country supported the Association generously. Locally, the OVTLA and Belmont Trades and Labor Assembly donated money to their cause, as did steelworkers from local independent companies. The lodge at Follansbee, West Virginia sent $\$ 500$ to the national office "to be used to help the strikers who are in need of the necessaries of life in the tin mill strike at New Castle, Martins Ferry, Wheeling and Elwood." 82 By October, the secretary reported that the union was financially stronger than it had been before the strike and able to assist "every needy person." 83

Meanwhile, AFL organizers were meeting with as little success as the Amalgamated organizers had. Emmett Flood, a general organizer for the AFL, went to Morgantown, West Virginia, to try to organize the workers at the small Sabraton plant but was run out of town by George Grubb, the chief of police, and Al Layton, the mayor. AFL Secretary Frank Morrison, 
who became the chief official spokesman while Gompers was in Europe, announced publicly that Flood "had a perfect right to be there," but Grubb, claiming to be carrying out specific orders of the mayor, told Flood to leave town or the mayor would not be responsible for what happened. Morrison said that he would be sending Flood back to Morgantown "to exercise his rights of free locomotion and free speech and to insist that the officials of Morgantown give to him the protection that any other citizen of the United States is entitled to." ${ }^{84}$ The mayor denied that he had any involvement in Flood's ejection or the denial of any of the organizers' constitutional rights. When Flood returned to Morgantown, he found out that Tom O. Jones, one of three Amalgamated organizers there, had been knocked down on the street by a complete stranger and that the atmosphere had not changed much since his previous visit. The union was unable to get any of the workers to leave the Sabraton mill. ${ }^{85}$

At the beginning of August, both Charles Lawyer, president of the TPWIPA, and P. J. McArdle wrote to Frank Morrison requesting permission to call a meeting of the heads of the various major unions to, in Lawyer's words, work out "a general policy for all the organizations to pursue to combat the open shop movement." ${ }^{, 86}$ Morrison sent a letter inviting the various labor leaders to a meeting in Pittsburgh. Several of the leaders gathered in early October 1909, but John B. Lennon of the Journeymen Tailors Union of America refused to attend protesting that he was "unalterably opposed first last and all the time to these conferences of officials who go without direct sanction from their union." He explained that too often "their judgment is swamped by their sympathy with the people who are engaged in the struggle and declarations are made which cannot possibly be fulfilled, the expectations of the people involved are raised by the declarations made and when there is no realization they get sulky and drop away and go back to work." ${ }^{87}$ Others, like Francis Feehan and Van Bittner of the UMWA, and representatives and organizers from a few other unions did meet with P. J. McArdle on October 3. They made plans to meet in Harrisburg on December 9 to discuss how to combat the oppression of the Pennsylvania state constabulary in light of the conflict in New Castle and another strike taking place in McKees Rocks. ${ }^{88}$

In October 1909, P. J. McArdle issued a circular outlining a broad based organizing drive beginning "with the blast furnace industry and running through all departments of the steel industry including tube, structural, rail, bar, and other departments." The cause of the poor 
working conditions of the steel workers, McArdle explained, was the lack of organization. "Believing that the men of the steel and iron industry realize the crying need for such an organization," the union, McArdle continued, extends an invitation to the men in all the departments of the mills to "join in the work of cementing all the workers of this great industry into a powerful organization for their mutual protection and welfare." He concluded by urging the men to "forget that you are English, Irish, Welsh, Slavish, Polish, German, Croatian, Italian, or Hungarian. Remember always that you are a working man with interests in common with, and inseparable from those of all other workingmen." 89

The national AFL convention opened in Toronto, Canada on November 8, 1909. P. J. McArdle brought a resolution from the Amalgamated Association that asked the delegates to recognize that the United States Steel Corporation was "the most formidable and aggressive enemy" the labor movement faced, and that "we believe the thorough organization of all branches of its business is the most important and necessary work that could engage the attention, time and effort of the American Federation of Labor" and its affiliates. ${ }^{90}$ McArdle also proposed a second resolution that all organizations affiliated with the AFL pay twenty-five cents per member annually to create a National Defense Fund, "to be used to help any organization engaged in a strike or lockout, when their funds are depleted." 91 The convention adopted his first resolution, and in accordance to the resolution a meeting was scheduled to be held in the Monongahela Hotel in Pittsburgh on December 13, 1909. ${ }^{92}$ Finally, the convention acknowledged the "great odds" against the AAISTW and the TPWIPA and expressed the hope "that every wage-worker employed in those industries may be thoroughly organized in the unions where they properly belong, their wages increased and their conditions of employment improved." 93

The meeting at the Monongahela Hotel brought together about two hundred delegates of various unions. They planned to discuss a great variety of issues including the strike of switchmen in the Northwest, the strike of the handmade glass blowers in the middle states, but of central concern was the strike against U. S. Steel. Samuel Gompers presided over the meeting and assured reporters that it would be "prolific of great results." 94 Rumors of great and radical changes in the labor movement were circulating in Wheeling. One such rumor claimed that the Amalgamated Association would call the strike off so that steelworkers could "start anew" and 
reorganize "on a broad basis." "95 It was truly a meeting of "great labor leaders who have won great strikes," brought there for the purpose of plotting a course to organize the United States Steel Corporation. George W. Perkins of the cigar makers, John Hays, secretary of the International Typographical Union, James O'Connell, president of the machinists association, Tom L. Lewis, president of the UMWA, and Frank M. Ryan, president of the structural iron workers, were all in attendance, not to mention the leaders of the AFL. ${ }^{96}$

It is highly possible that such a radical reorganization was discussed, but what came out of the meeting was a resolution replete with radical rhetoric, vilification of the corporation, but not radical change. "Grown rich and powerful by the consent and good will of the people or our country," the resolution text read, "this corporation in its mad greed and lust for still greater riches and power sweeps aside, makes and unmakes law, its enactors and executors, and is now engaged in an effort to destroy the only factor - the organizations of its employees - standing between it and unlimited, unchecked and unbridled industrial, political, social and moral carnage." They criticized U. S. Steel and corporations in general because "while centralizing its powers, it proposes to individualize its employees. It arrogates to itself the right of combination, but denies this right to its workers." They resolved that the AAISTW and TPWIPA should combine and that "an earnest and systematic effort be made to thoroughly and completely organize all employees in the iron, steel and tin plate industry and subsidiary co-related trades." Finally, they asked all the national unions to send at least one organizer to execute the plan. ${ }^{97}$ There were rumors the day after the meeting at the Monogahela Hotel ended that organization efforts were already beginning at the Bellaire basic steel plant, which had been non-union for years. $^{98}$

Walter Larkins, of Martins Ferry, outlined the AFL plan for local reporters which was to go into effect on the first day of 1910. He said they hoped to have up to forty organizers in the field attacking all departments of U. S. Steel by early January. In addition, they would levy all union members ten cents which, hopefully, would bring in \$250,000 to help support the strikers and pay for organizers, and lastly, a committee from the AFL would meet with President Howard Taft and the governors of the states involved to demand an investigation of the "methods employed by the corporation and the conditions in their plants." 99 
"From a purely local standpoint, possibly, it is well that the Federation has taken up this matter," the Wheeling Intelligencer assured. "The fight against the steel corporation will not be confined to a few local plants like those in Wheeling and Martins Ferry. This, therefore, will not be the sole battle ground. Other communities are pretty likely to be involved, which will at least demonstrate that there are communities besides our own in which the policy of the steel corporation is not looked upon with favor by the workingman." Again the newspaper expressed the hope that the issue would be settled quickly "for all time" because the public "suffers from the frequent labor disputes without the ability to correct or hinder them." 100 What the editor was really expressing was the fear that U. S. Steel would remove the plants and the equipment to other cities where labor was more compliant. This fear was not the invention of the newsman but had been promoted by the company.

At one point during the strike, the district manager of the American Sheet and Tin Plate Company called the leading businessmen of Wheeling together for an informal meeting. At the meeting the manager read a letter from the President Pargny that said that the company was withholding \$200,000 that had been set aside for improvements to the LaBelle plant but that now he could not say that it would ever be spent. He claimed that a high ranking official of U. S. Steel had remarked that "unless our operations in that locality could be carried on with less trouble incident to labor, and more cooperation on the part of the community, the natural outcome would be the boarding up of the plants . . . and moving them elsewhere." It was later rumored that the equipment in local plants was designated to go to Gary, Indiana, but this never happened. ${ }^{101}$ In December, 1909, the Wheeling Intelligencer reported that the Aetna-Standard was already being dismantled, and the equipment was being removed to Gary. ${ }^{102}$ This also proved to be untrue, but the effect on the businessmen, however, was very real. Businessmen in New Castle expressed hopes that the Wheeling plants would be dismantled and the equipment moved to their city. ${ }^{103}$

G. O. Smith, a leading real estate agent in Wheeling, expressed what was probably the typical belief of the local business community. "Wheeling has been handicapped in many different ways," he told the Wheeling Intelligencer. The "difference between capital and labor has probably kept Wheeling back twenty years" and so has "the inefficiency of our city government in caring for the city's business."104 After the strike, businessmen in Wheeling 
formed the Municipal Improvement League. Different organizations had already formed in Wheeling that ostensibly sought to boost industry and commerce, but also harbored very negative views of labor. In 1911, OVTLA singled these organizations out as a threat separate from U. S. Steel concluding that "the situation in Wheeling is not as bright now as for the future, unless organized labor will rally together to meet its foes: with conditions as above stated we have to battle the Board of Trade, the Business Association, and to top it off yet they have formed a Municipal Improvement League, its purpose no doubt which you are familiar with." 105

Whether or not the atmosphere in Wheeling was growing more hostile to labor, as the OVTLA argued, was a matter of debate. The Wheeling Board of Trade, for example, formed in 1900 and brought together many prominent businessmen in the area for luncheons and dinners to hear speeches. ${ }^{106}$ They also organized such events as a contest in August, 1909, to decided what the city slogan should be, ultimatley deciding on "Wheeling Means Business."107 Roy Benton Naylor, the secretary of the Board of Trade, said that the Board had "been a factor in our civic advance, standing not only for things commercial and industrial but also promoting many municipal improvements, which in the last analysis mean better business and more prosperity for all." The Board organized the Playground Association, which funded the construction of playgrounds in different places in the city promoted the "beautification" of the city in general. The Board also organized the Associated Charities "backing the bond issue and assessment plan," and formed the Market-Auditorium Company which raised $\$ 150,000$ to build an auditorium. The auditorium would seat about 4,000 people and, it was hoped, would attract big conventions. Naylor concluded that Wheeling was developing from a "typical oldtime manufacturing town" whose "sole object" was to make money into a "community with the higher civic aims which follow a realizing sense that good government, municipal improvements, playgrounds, organized charities and other things along these lines" ultimately pay financial dividends as well. ${ }^{108}$ The Ohio Valley Trades and Labor Assembly obviously had a very different view of these organizations, and charged the Municipal Improvement League, which was ostensibly intended to make the city government more efficient, with "slavish submission to the will of the giant steel trust looking toward the wiping out of the influence of labor in the entire Wheeling district." ${ }^{109}$ 
After the strike, the OVTLA was aghast when Tom L. Lewis, now the former president of the UMWA and head of a coal operators association, spoke in favor of the Municipal Improvement League. Lewis allegedly told one member of the OVTLA that "it would be better if the mills were allowed to run here," implying that if a change in city government were necessary, so be it. J. B. O'Toole, a delegate of the OVTLA said that he considered Lewis to be "a Benedict Arnold to the Labor movement." The Wheeling Majority likened the Municipal Improvement League to the National Civic Federation (NCF). Workers believed that the NCF, presided over by John Mitchell, another former UMWA president, was an organization that only gave the high officers of national unions an opportunity to betray the workers. The president of the OVTLA argued that if they let the Municipal Improvement League and the business associations "have their way" that the conditions in Wheeling would eventually become similar to other parts of West Virginia, where a coal miner told him that he worked for a whole year and "did not draw during that time one red penny."110

On December 1, 1909, in an attempt to resume operations at the Aetna-Standard plant in Aetnaville, the American Sheet and Tin Plate Company started up four mills. Though several pickets were in the vicinity of the plant at 8 a.m. when the furnaces were lit there was no disorder, but when the workers came out after the first shift, a crowd of about 200 were there to protest the men working under the open shop. While there were rumors of trouble, the Wheeling Register only reported that "several warm arguments" were alleged to have taken place. On December 2, there were even more rumors, and one worker told the mayor of Martins Ferry that shots had been fired. That night about 700 people gathered around the plant. When the southbound Cleveland and Pittsburgh passenger train pulled into town, the non-union workers boarded it, and as the train pulled away three or four shots were fired at it. That night, seven company guards got off another train and found themselves right near the strikers' headquarters on Crawford Street. Tensions were high, and violence erupted. By December 4, four men had been wounded during the intermittent gun battles, three company guards and one striker. ${ }^{111}$

Llewellyn Lewis charged the company guards with starting the trouble in every instance of the previous few days. The workmen, he said, were law-abiding and intelligent. They would not use anything but lawful methods in their just fight. "The whole question," he reiterated for the press, "is the issue of a trade agreement and the refusal of the company to grant us a 
conference. We worked under the agreement since 1901, and were proud of our relations with each other. It evidently is the aim of the company to crush the Amalgamated Association." On December 4, Joseph Bishop, former president of the Amalgamated Association and the current secretary of the Ohio state board of arbitration arrived in Martins Ferry with hopes of bringing order to the situation. Bishop's father had been an ironworker at Wheeling's Top Mill, and Bishop told a reporter from the Intelligencer, "I was only a small boy when we moved from Wheeling to Pittsburgh, but I still remember many of the places and incidents that occurred when we lived here."112 He met with Lewis and some company officials, but nothing came out of those meetings. That morning, the Belmont County sheriff wired Ohio Governor Judson L. Harmon describing the three days of shooting incidents including one during which strikers shot at an ambulance that came to attend to wounded guards. "Have made every effort to cope with situation and have exhausted my power," he wrote. "Mob well armed. Have satisfactory proof that previous preparations were made by mob. Leader said they were looking for another Homestead and were prepared for it. Mob now numbers over 700. Many rioters from West Virginia state. Absolutely necessary that 1,000 troops be sent at once."113

On Sunday, December 5, as the sheriff had requested, 1,000 soldiers from the Ohio National Guard arrived in Martins Ferry. The Register reported that the "presence of soldiers with machine guns trained on all avenues leading to the plant and soldiers on all sides had the effect of dispelling all signs of disorder and resistance that marked the situation on the Ohio side from Wednesday until Sunday." The soldiers were said to have been surprised to find the situation quiet and orderly as the reports they had been given led them to believe quite the opposite. Pickets were prevented from coming within 1,000 yards of the Aetna-Standard, and there were no further incidents. Ultimately the company's efforts were in vain as the men who worked the four mills on December 1 and 2 did not return to work. On December 7, as there was little for soldiers to do other than patronize local stores and barbers, half the force was sent home. ${ }^{114}$ By December 16, all the troops had left and had even donated the remainder of their rations to the strikers before doing so. District Manager Cecil Robinson was reportedly instructed to close the plant down again and send the guards away. ${ }^{115}$

In the aftermath of the incident, the Wheeling Majority declared it a victory for labor: “SO FAR AS THE WHEELING DISTRICT IS CONCERNED THE TRUST HAS BEEN 
ABSOLUTELY WHIPPED!"116 Twenty-four indictments were handed down by a Belmont County grand jury, but the Majority complained that there were no indictments "against any Trust thug." Of the twenty-four indictments, eight were for felonies. Both Llewellyn Lewis and Walter Larkins of the Amalgamated Association received indictments for felonies. ${ }^{117}$ Lewis was indicted on two counts of shooting with intent to kill or wound. ${ }^{118}$ An editorial in the Wheeling Intelligencer demanded justice: "Law is made for all men. The laws that penalize murderous assault and destruction of property cannot be suspended for the benefit of any particular class. It is the duty of the Belmont County officials to bring the men who encouraged and took part in these riotous demonstrations to justice." Yet again the editor concluded that there was no point in continuing the strike and that "even the most reckless and rash of their leaders must by this time be convinced of the utter futility of their efforts."119

The jury for the trials was selected in May 1910. Of the twelve jurors, seven were farmers, two were retired, one was a hardware dealer, one a barber, and one an express driver. ${ }^{120}$ On May 6, eleven of the strikers, those charged with assault and battery and rioting, were acquitted, ${ }^{121}$ and on May 13, David Jenkins, who had been indicted for shooting at the passenger train on December 2, was also acquitted. ${ }^{122}$

Gompers made an official statement on January 1, 1910, condemning the trust for paying dividends on watered stock, having attorneys "notoriously present" at every legislative body where favors could be bought, controlling judges who handed down unjust injunctions, destroying the free market in iron and steel, and controlling certain daily newspapers to spread its propaganda. He said that its "crowning criminality" was "its bold and heartless enserfing of labor." The ten cents per member levy on all unions that the AFL now called for was to help fight U. S. Steel policies, which by “methodically” hiring "freshly arrived immigrants," by substituting young men for fathers with families, by closing mills and disheartening communities, was resulting in "the systematic destruction of the labor movement." For these reasons, Gompers pleaded, "the moral support and financial assistance of all are necessary."123 Support came from unexpected sources such as the Eight Hour Tobacco Company of Cincinnati that sent \$100 to the Amalgamated Association. ${ }^{124}$ Valentine Reuther, president of the OVTLA, hoped that other organizations "upon whom fortune has shone more favorably will lend these brothers not only their moral, but financial support.",125 
The AFL's announcement that the organization was entering the battle in full buoyed the strikers' morale. According to the Wheeling Majority: "Probably half a hundred organizations will have representatives, tried veterans in labor's battles, enter the arena, and the striking mill men have more reason than ever to feel their cause is not lost, as the daily papers have so often told them." The newspaper also expressed hope that this signaled a new era, one of industrial unionism. While previously "craft unions have held forth in the steel production field, and whichever organization lucky enough to get a scale signed, paid no attention to other employes not so fortunate." Now, the "Trust finally threw down the mask, showing its open antagonism to all organizations, and this act has forced all organizations, in self defense, to come together. Hence the combined fight, with its magnificent lesson of working class solidarity."126

These hopes, however, did not last long. By all accounts, the AFL's craft union approach handicapped the organizing drive, and it ended without concrete results by the second week of February, 1910. ${ }^{127}$ According to P. J. McArdle, however, including the four AFL general organizers already working, less than ten organizers from AFL and its affiliated unions had reported by February, and three of them devoted a considerable amount of their time to their own organization and not to the Amalgamated Association. This, McArdle said, "precluded the possibility of them adapting themselves to any fixed program that we had agreed upon." This pitiful effort, as McArdle pointed out, would obviously not be enough to tackle the the task of organizing the enormous corporation. The campaign had turned into a "huge farce" that was damaging to the morale of the strikers and could not continue. ${ }^{128}$ Regardless of the organizers craft union approach, there simply was not enough response for the AFL initiative to make any difference in the strike.

In February, the Wheeling Board of Trade decided to buy the LaBelle tin plant from U. S. Steel. "Wheeling business men realize that their prosperity depends upon the steady operation of industrial plants in the city and vicinity and the benefits that would accrue if this plant could be purchased and placed in operation are obvious," the Wheeling Intelligencer reported. ${ }^{129}$ Matt Greer, of the Prosperity Lodge, said, "You can bet all that you are worth that the American Sheet and Tin Plate Company won't sell the mill to them. It looks to me like a political bluff."130 The company did refuse. One businessman who met with E. W. Pargny reported that Pargny said that "under no circumstances would the trust sell the plant."131 The Board began making plans to 
build its own sheet mill. ${ }^{132}$ The Wheeling Intelligencer urged the local businessmen to build the new mill because in "Wheeling and Martins Ferry thousands of skilled workmen are idle. Most of the men have lived for years in this neighborhood; they have their homes and their families here. They will remain here if there is a decent opportunity for them to earn a living." Otherwise, of course, they would leave. ${ }^{133}$ The New Industries committee of the Board of Trade scouted out locations for the new mill, discussed its profitability, petitioned for political support, and ultimately abandoned the idea altogether. ${ }^{134}$

On March 14, 1910, one picket, Solomon Edwards was shot by a non-union worker who lived in Martins Ferry but was working at the Steubenville LaBelle plant. Edwards and several pickets approached Emanuel Robinson, who drew a pistol and fired two shots at the pickets. One bullet struck Sol Edwards, tearing through his liver and puncturing his lung, and he was taken to the City hospital. The twenty-seven year old Edwards was a well-known athlete who played for the Wheeling Tigers football team. The doctors there were unable to save him, and he died on March 16. The newspapers were quick to label Robinson a "Vicious Negro Scab." Robinson, a bricklayer who lived in Martins Ferry, secured work at the Steubenville LaBelle plant and had been spending his weekends with his family in Martins Ferry. ${ }^{135}$ Five thousand people attended Edwards's funeral, including Llewellyn Lewis, Michael Tighe, and Joseph A. Bowers. Lewis said during the Riverview Cemetery service that Edwards "was always a champion and defender of the rights of his fellowmen, and could he have lived to take part in future contests his voice would always have been heard in the defense of the principles for which he was so cruelly slain." "136 Michael Tighe wrote to the Amalgamated Journal that "never in the history of the Ohio Valley, was there such an outpouring of men and women to do honor to one who had proved himself worthy of the crown of immortality."137

It was revealed during Robinson's trial that the pickets had attacked him, and that one had struck him with a blackjack before he drew his pistol and fired. As Edwards lay dying in the hospital, he admitted to Belmont County Prosecuting Attorney that they had attacked Robinson. At first they tried to dissuade him from working, but Robinson refused to listen. Edwards explained: "This fellow is blacksheeping, you know. He was trying to down us, anyhow. I did go up there for the purpose of licking him, but that was as far as it went. He pulled a gun on me 
and shot twice. That is all I know about it. I had to get away." Robinson was acquitted on the grounds of self-defense.

O. Bowen, or "Hugo," a frequent writer to the Amalgamated Journal and a socialist, raised the rhetorical question of Edwards' death: "Who murdered him? The 'scab' was simply a tool (consciously or unconsciously) ready to do anything to uphold the profit system. Bro. and Comrade Solomon Edwards was “A SOLDIER OF THE INDUSTRIAL REVOLUTION.”” Hugo went on to say that the "capitalistic system has made men desperate by oppression and life, on the terms offered by the tyrants upheld by that system."138 Others focused on Robinson's release as more proof that the state and the courts were against the strikers saying that the "discharge of the scab negro that shot Sol Edwards only goes to show how little consideration the striking working men have in the courts. It is a sure thing that the workers must fight single handed their battle for human rights against all combined power of capitalism and the courts." 139

By the spring of 1910 the strikers' morale began to flag. The American Sheet and Tin Plate Company announced in April that the preceding month, a new record for sheet production had been set "without operating the Aetna-Standard Works at Bridgeport, Ohio, which is capable of producing about 12,000 tons a month," reported Iron Age. ${ }^{140}$ While this may have been pure propaganda aimed at the strikers, such reports were increasingly disheartening to them. Then U. S. Steel granted a wage increase on April 21, which put wages above the Amalgamated Association's scale. ${ }^{141}$ P. J. McArdle insisted that the wage increase would not hurt their cause and that the union had not lost any ground despite the hardships that accompanied the winter weather. He was sure that their situation would improve as the weather got warmer. ${ }^{142}$ Truthfully, however, by the summer of 1910, support for the strike was growing scarce.

In early August, 1910, a vote was taken to decide if the strike should be continued. Nationwide the union voted 942 to 548 to continue the strike. But 490 votes to keep the strike on came from the McKinley lodge in Elwood, Indiana. The Mountain City Lodge of Martins Ferry voted 177 to 101 to end the strike, as did the Lewis Avon Lodge of Aetnaville by a margin of 126 to 48. Sharon and New Castle also voted to end the strike, but Wheeling's Prosperity Lodge voted 88 to 3 to keep striking. However, the vote reveals that less than 1,500 votes were taken from the strike centers which shows that many of the Amalgamated men had already abandoned the union. The 278 votes from the Mountain City Lodge, for example, were less than half of the 
600 eligible voters. ${ }^{143}$ The men were undoubtedly working in other industries, independent sheet and tin plates plants, or scabbing by this time.

On August 23, the executive board of the Association declared the strike at an end despite general vote of the members in favor of continuing. The general vote had no authority, only the Executive Board of the convention of delegates could determine policy. ${ }^{144}$ The TPWIPA decided to continue the strike without the AAISTW, but soon they too were forced to admit defeat. ${ }^{145}$ P. J. McArdle and John Williams distributed a circular to the members explaining that the strike had "reached a point where little or no hope can be entertained of reaching an amicable settlement through an agreement with the company because of the powerful resources of the company, and of the repeatedly expressed desire of a large number of men to have the strike declared off." The New Castle and South Sharon lodges had requested the strike called off, and the Lewis Avon lodge in Martins Ferry had passed a resolution to the same effect. The strike officially ended after August 27, 1910. ${ }^{146}$ After the strike, the lodges in the Wheeling district voted to retain their charters, but the workers in New Castle were finished with the union. ${ }^{147}$

On Labor Day, 1910, a parade of three thousand men and seven brass bands made their way through the streets of Wheeling. Prosperity Lodge No. 3 of the Amalgamated Association, representing the LaBelle tin plate workers, led the parade. The men of the local lodges including the "over-river-boys" all wore "Sol Edwards Martyr" badges. It was probably the last public display by the local lodges that lost their contest with U. S. Steel in the 1909-1910 strike. ${ }^{148}$

The Wheeling Intelligencer was critical of the union, as always, pointing out that they had predicted the strikers would lose from the beginning. One editorial argued that many of the strikers probably had not wanted to quit work but that "the radicals and extremists lead them on, and the result has been one of the most disastrous labor conflicts ever carried on in this valley." 149

Wheeling had been the "center of resistance." Proudly the striker had kept the local plants shut down for the entire strike, but orders were merely shifted to other locations where plants were successfully opened with strikebreakers. ${ }^{150}$ Thus, the loss was particularly poignant for the Wheeling steelworkers. The Wheeling Majority summarized the sentiments of the workers at the end of the strike:

The mills are resuming. The men are returning to work. Once again the rolls will rumble and the fires will blaze. And the men will toil through long hours at the top notch of 
physical endeavor. They will be so exhausted after the end of the day's work that they will not be able to enjoy the better things of life and so they will be called stupid. They will be so worn out that they will take stimulants, and they will be called drinking men. Some of them will collapse; some will contract ailments that kill, and all will shorten their natural lives. For all of this they will receive about a fourth of what they produce. ${ }^{151}$

The other three-fourths, the column observed, would be kept by the capitalists, some of which "Carnegie will use to carve his name above the door of a library." Meanwhile, the worker will take his one-fourth and divide that up. He will give one-fourth of his money to the landlord and the other three-fourths to merchants. The merchants will give some of that to the newspapers, and the worker's money continues to be divided among others. "Thus the landlords, the merchants, the newspapers and all the other business interests depend upon the men who work. Yet they did not help them when the workers struggled to better their conditions." Now, the Majority lamented, the "workers are going back to work in the mills without the protection of the union. This means that wages will be lower and working conditions worse. To the sentimental side cold commercialism is deaf so we will merely call attention to the fact that less wages for the men means less wages for the merchants." But, the column concluded, "Unionism cannot be crushed as long as there is life, for unionism is the spirit of life." 


\section{Chapter Four: Trying to Change the Union; Too Little, Too Late}

The 1909-1910 strike convinced many, and was only further proof for others, that the craft union policies of the conservative leadership were no longer effective in the face of the technological changes in the mills and the creation of multi-plant corporations. The Amalgamated Association had never been able to make a successful transition from iron to steel, and the leadership had continued to concentrate their organization efforts among skilled workers. By the time of the strike, out of a corporation of about 118,000 employees, the union counted less than 8,000 among its members. ${ }^{1}$ The gains in membership in the $1890 \mathrm{~s}$, after the Homestead strike, had been misleading. Union leaders believed that they could find refuge in the finishing plants that relied on highly skilled workers, but the creation of U. S. Steel negated the strength the union possessed through their skill. The mergers enabled the company to wait out the union and re-open select plants from the existing labor pool. The union was nearly powerless in these circumstances because their strategy relied on the strategic importance of their skill to the company. $^{2}$

Many members had foreseen the need to restructure the union to remain an effective collective bargaining agent under the new circumstances. They pushed to change the Amalgamated Association away from craft unionism toward industrial unionism; a union that disregarded skill as either a qualification for membership or for special status within the organization. There were movements toward industrial unionism throughout its history but they all ended in failure.

For various reasons, the Amalgamated Association of Iron, Steel, and Tin Workers had always been resistant to change. First, the AAISTW was repeatedly weakened by internal conflicts and an inability to make local lodges adhere to its national policies. The second reason was that the constitution put all the power into the hands of the delegate convention. Because the membership already consisted of only the most highly paid workers, the annual convention was, thus, made up of the elite of the elite, the "labor aristocracy." The labor aristocracy had the most to gain from maintaining the status quo and the most to lose from radical change. Finally, the AFL reinforced the conservative policies of the AAISTW through its financial support and sheer influence. 
The failures of the union in key strikes like the 1909-1910 strike and its conservative response to the losses led members to seek forms of organization other than trade unionism to achieve economic justice. Often these alternatives were in competition with one another for adherents, and the result was a fractured labor movement. Independent companies facing this divided front were able to push U. S. Steel's open shop movement into their mills, further diminishing the steelworkers' opportunities for collective bargaining.

Industrial unionism, though it attracted numerous subscribers within the AAISTW, was contradictory to conventional wisdom. Throughout its history the Amalgamated Association was an exclusive union. Even at its height just before the 1892 Homestead strike, only 24,068 of the approximately 100,000 workers eligible for membership actually belonged. ${ }^{3}$ In his study of the steelworkers published in 1910, John Fitch observed that the "Association has always been an organization of skilled workers and has centered its efforts on securing better conditions for that class of labor alone." ${ }^{4}$ Through the first decade of the union, membership was expressly limited to puddlers, boilers, heaters, roll hands, nailers, hammermen, and helpers, all of whom were skilled workers. ${ }^{5}$ This approach to organization defies the axiom that there is strength in numbers. Why would the members of the Amalgamated Association consciously limit their numbers?

The reason for this policy is found in the roots of the organization. The Amalgamated Association was created by the craft unions of the different trades in the mills. The five prominent and successful national ironworkers' unions which formed the Amalgamation in 1876 were the United Sons of Vulcan (boilers and puddlers), the Brotherhood of Iron and Steel Heaters, the Rollers and Roughers of the United States, the Iron and Steel Roll Hands' Union (catchers, hookers, helpers, and others), and the United Nailers. ${ }^{6}$ Each union represented skilled workers who labored in the same mill but were separated by their work and remained isolated in their respective unions. When they joined forces, they brought with them the principles of organization that had brought them success in the past.

Ironworkers viewed themselves as producers and were paid according to how much they produced. $^{7}$ This was not viewed initially as a form of wage labor, but as part of a system of production that resembled the artisan system. The artisan system had been in use in all branches of manufacturing for centuries. In that system, masters selected young men to be apprentices to 
live with the master and learn the trade over many years. Ultimately they would graduate to the journeyman level and perform work that required more skill. Finally, the journeyman would become a master and select his own apprentices and journeymen. ${ }^{8}$ While ironworkers ostensibly worked in a far more industrial setting, the system was very similar. The skilled worker, whether he was a puddler, roller, or any of the other skilled workers in the mill, would hire his own helpers and teach them the skills of working with metal. These helpers had various levels of skill and experience and would ultimately become puddlers or rollers in their own right. ${ }^{9}$

Like artisans, ironworkers coveted the skills of their trade. As one ironworker, who later worked in the Elwood tin plate mills, said:

My father was an iron worker, and his father before him. My people had been workers in metal from the time when the age of farming in Wales gave way to the birth of modern industries. They were proud of their skill, and the secrets of the trade were passed from father to son as a legacy of great value, and were never told to persons outside the family. Such skill meant good wages when there was work. But there was not work all the time. Had there been jobs enough for all we would have taught our trade to all. But in selfprotection we thought of our own mouths first. All down the generations my family has been face to face with the problem of bread. ${ }^{10}$

Thus, like the artisan, puddling or rolling iron was much more than wage labor; workers viewed their skills as assurance of a livelihood.

Meanwhile, working around the skilled crews was an ever-growing army of day laborers who fed raw materials into the blast furnaces, transported ingots and bars around the mills, and performed the other menial tasks of the mills. These unskilled workers were not admitted into the upper echelon of the iron and steel workers and were excluded from the union. Skilled workers kept abreast of prices, demand, production figures, and everything else on the business side of the industry. For example, one of the reasons the founding members of the Sons of Vulcan began meeting was to discuss these business conditions. Furthermore, they were familiar with the fundamentals of organization: the procedures and protocol, the history, and the wisdom of the leaders. ${ }^{11}$ One day, the apprentice, too, would have learned and experienced enough to take an active part in the union. The unskilled worker was viewed by the various skilled crews as nothing more than a strong back who cared little about business conditions and did not have a permanent interest in the mill. For the members of the craft unions who were all skilled workers with years of experience, it made no sense to admit the masses of these unlearned workers. 
Since the Amalgamated Association was an amalgamation of craft unions, its constitution and ideology reflected the constitutions of the constituent organizations. The Association's constitution explicitly excluded all but the skilled workers. Also it placed all the power in the national convention of delegates, and strikes had to be sanctioned by the national lodge or financial support would be withheld and charters revoked. These features prevented changes from originating in one local movement and spreading, ${ }^{12}$ but when the great changes set in motion by the Bessemer process began, the union was not well equipped to deal with them. Their organization was based on experience and tradition, and the skilled workers were conservative and resisted change. ${ }^{13}$

Contemporary critics and historians alike have attributed the union's decline to its leaders' conservative nature and their adherence to the status quo. ${ }^{14}$ While that is certainly true, it is not the whole picture. The constitution of the Amalgamated Association evolved as the officers and delegates responded to the pressures of the changing industry, ${ }^{15}$ and there were repeated attempts to change the conservative nature of the organization. By the 1880s, many were already promoting industrial unionism. The leading proponents of industrial unionism at the time were the Knights of Labor. In fact, the Knights sought to create an organization that included all working people regardless of their industry. The only people excluded were bankers, stockbrokers, lawyers, gamblers, liquor dealers, and others whom they viewed as parasites. The Knights of Labor began as a secret organization replete with rituals and was not referred to publicly prior to 1882 , when the organization experienced a rapid ascent. By the summer of 1886 , they were the most powerful labor organization in the country with nearly 750,000 members. ${ }^{16}$ Unskilled workers were drawn to the organization, and its influence was felt in the steel industry.

The Knights formed local assemblies in mills from Andrew Carnegie's massive Edgar Thomson plant to the relatively small nail mill in Mingo Junction, Ohio. ${ }^{17}$ Their influence on the iron and steel industry has yet to be fully explored, but it was enough to cause concern among the Amalgamated Association leadership. In 1888, Secretary William Martin of the Amalgamated Association, urged the union to "take in every man in the mills outside of common labor, and him too, if necessary." The union must, he asserted, counter the "inroads" being made by the Knights of Labor. Accusing the Amalgamated lodges of being "aristocratic" and "narrow," he 
urged them to be "liberal and admit to membership the men whom the Knights of Labor are playing to reduce wages ... We mean the unskilled workmen ... Yes, even the daily laborer. We have nothing to lose and all to gain by the admittance of these men. All they ask is recognition. Failing to get that they naturally seek and get in the Knights of Labor."18

The Knights drifted into obscurity after a failed railway strike in 1887 , but their influence on the Amalgamated Association remained. While members of the Knights of Labor lost faith in the organization and defected to the AFL, ${ }^{19}$ the Amalgamated Association still pushed toward industrial unionism. In 1889, a measure was adopted opening the union to all workers directly involved in iron and steel production, even the common laborer at the discretion of locals, ${ }^{20}$ but the broad based organization never happened. This was mainly because local lodges still discriminated against the "helpers" or semi-skilled workers, the unskilled laborers, ${ }^{21}$ and especially immigrants. $^{22}$ The organization remained "top-heavy" in character. ${ }^{23}$ At the time of the Homestead strike in 1892, still only a small percentage of the workers in the plant belonged to the union. Some may not have had an interest in the union, but many, especially the immigrants were still excluded, if not expressly, in practice. Even after the Homestead strike, when the union turned away from basic steel mills and focused on the tin plate industry, some tin plate workers were not admitted. For example, when the tin house workers approached the Amalgamated Association in 1898, they were told to form their own organization as they would be able to more effectively protect their interests. ${ }^{24}$

After the Homestead strike, the rank and file of the union became discontented and complained that the organization was not democratic enough. In 1894, one local in Akron, Ohio, proposed that wage scales and constitutional amendments be voted on in referendums. The delegates' convention, however, rejected this. In 1901, it was proposed that officers be elected by the members at large, but this too was rejected. ${ }^{25}$ The message was clear: the union would continue to be run by the delegates convention and not by the membership at large.

The concentration of power in the elite began to fracture the already weakened union. In 1907, puddlers, who by now were an insignificant part of the iron and steel industry but a significant part of the union, were fed up with the lack of attention their branch received. They left the Amalgamated Association en masse and reformed the old Sons of Vulcan. ${ }^{26}$ They remained a separate organization for several years until their local lodges were broken by 
independent employers such as the A. M. Byers Company in Girard, Ohio. During World War I, many puddlers would rejoin the Amalgamated Association. ${ }^{27}$ The exodus of the puddlers fractured the Amalgamated Association all the way down to the local level. Michael Tighe appeared at the OVTLA's April 28, 1907 meeting to oppose the admittance of the Sons of Vulcan No. 1, of Benwood, into the organization. The OVTLA president at the time, William Maxwell, was a delegate from Sons of Vulcan No. 1. After much debate and internal conflict, Maxwell left the OVTLA for the "sake of peace and harmonie [sic]," and took the Sons of Vulcan No. 1 with him. ${ }^{28}$

Even workers in the sheet and tin plate mills felt slighted by the Amalgamated leadership. In 1908, John A. Conkel, representing the roughers, pair heaters, heaters' helpers, openers, and shearmen of the Aetna-Standard plant, also known there as the "day-hands," wrote directly to Samuel Gompers complaining that the rollers and heaters had not treated them fairly. The dayhands had recently been put on the tonnage basis as opposed to a daily rate, and the result was a reduction in wages from anywhere between ten to forty percent. Conkel said that they were interested in forming a new lodge and had had three well attended meetings already. About one hundred and sixty had signed their roster locally, but if granted a charter, he was confident that "the day hands all over the country will organize at once as committees from different mills have been to our meetings." These workers, he assured Gompers, were not members of the Amalgamated Association nor had they ever been. Furthermore, they did not wish to belong to the AAISTW which was why they wrote directly to Gompers. If they had contacted the president of the Ohio chapter of the AFL, Llewellyn Lewis, who was also a vice president of the Amalgamated Association, they were sure he would "try to round us up for the A. A.," and the day hands, as Conkel put it, "don't want nothing to do with the A. A."29 Upon hearing about Conkel's request, John Williams of the AAISTW told the secretary of the AFL that the Federation must refuse them a charter. Firstly, he argued that the day hands" "very admission of not having taken any interest in the affairs of the Association is one of the pungent reasons as to why we were compelled to take a reduction on sheet mills this year." Secondly, Williams disagreed with Conkel saying that the day hands had "been mainstays of our Association and their sub-lodges." Williams concluded that the AFL could not be too severe in their condemnation of this upstart movement because "if carried out it cannot but result in the 
destruction of all organizations in that branch of the steel industry." ${ }^{30}$ Consequently, the AFL did not grant the day hands a charter.

Some who remained dedicated to the AAISTW continued to push industrial unionism. In 1907, Llewellyn Lewis found men at a sheet mill in Zanesville, Ohio, ready to organize, but they were afraid to enter the Amalgamated Association for fear of being discharged. Lewis reported that they were, however, willing to join the AFL, because the workers knew the company was "not so much opposed to them" joining the AFL as opposed to the Amalgamated Association." Contrary to Conkel's beliefs about Lewis, he suggested that the AFL grant the Zanesville steelworkers a charter with the hope that later they could be convinced to form an Amalgamated lodge. $^{31}$ Thus, unlike Williams, Lewis put organizing of the workers above the interests of his own union. At the beginning of 1909, Llewellyn Lewis argued that the "strength of the Amalgamated Association (or any other organization) depends on its comprehensiveness, and our aim must be to spread out and have every man working around the iron and steel mills in one organization." 32 In February he wrote to the Amalgamated Journal that he had been "for several years in favor of the initiative and referendum in our organization in making our constitutional laws and electing our officers." With initiative and referendum the delegate convention would still meet, but when the general membership thought the delegates had ceased to represent their best interests they could repeal or enact laws by a majority of the membership. The only objection he found was that some believed that the membership of the union was not competent to vote on laws or elect the officers. In response to this objection he quoted U. S. Senator Jonathan Bourne: "The man afraid to trust the people should not be trusted by the people." Lewis concluded with the hope that the issue would by "thoroughly thrashed out" in the Amalgamated Journal before the next convention met and that he would personally be willing to debate any officer on the matter. ${ }^{33}$

President P. J. McArdle immediately responded that Lewis's statement was "more in the nature of a challenge than as being an ordinary emphatic declaration in favor of a certain proposition." McArdle was opposed to the initiative and referendum proposition "in any of the numerous forms that it has been presented," and accepted the invitation to debate Lewis. ${ }^{34}$ In March, McArdle and Lewis met in Wheeling and debated the initiative and referendum matter. Each spoke for thirty minutes and then for fifteen minutes in response to one another. One 
member in attendance reported that "to say it was an interesting meeting is letting it down light." Those who were there found it thrilling and enlightening, but attendance was not good. "If the membership wanted a change as bad as some of the members try to make you believe, why the attendance would have better. I think if there was more time spent in trying to build up our organization, and less in the other 'isms,' we'd get along much better."35 Truthfully, many had already lost hope that the union would change. Poor attendance and unpaid dues were frequent complaints in early $1909 .^{36}$

At the 1909 convention, the initiative and referendum resolution was again voted down. After the June 1, 1909 open shop announcement, many members thought the failure of this resolution epitomized the problems with the union. W. H. Evans, a frequent writer to the Amalgamated Journal and the National Labor Tribune, complained bitterly that the "gang" had defeated the measure. Evans argued that if the "rank and file of the A. A. had been permitted to select their officers and had a voice in its affairs" the union "would not be in its present helpless condition upon the broad of its back with these combines grappling its throat." ${ }^{, 37}$ J. H. Gamble of Granite City, Illinois, said that the workers would not be faced with their current problems if they "had a strong fighting militant organization." Gamble argued that if they had followed "the writings of T. M. T. of Piqua, and Hugo of Martins Ferry, O., who have written for years for an industrial form of organization and made laws to that effect" then the American Sheet and Tin Plate Company "would have thought twice before that infamous and unjust proposition." 38

It was not until 1911, the year after the strike that the delegate convention decided that constitutional amendments would be put up to a referendum vote. Immediately an amendment was proposed to have national officers elected by referendum. Poor turnout for the vote left the issue to be decided at the following year's convention when it was adopted. ${ }^{39}$ The initiative and referendum amendment had little effect despite the years of effort to get it enacted. By this time the Amalgamated Association had been greatly reduced in membership and influence.

Discontent with the Amalgamated Association and trade union structure led to movements to try to circumvent both. During 1912 and 1913 there were two insurgent movements within the union. The first group, which called themselves the Industrial Iron and Steel Workers of America, formed in Niles when workers there walked out of the Empire plant. They wrote a manifesto that called for an organization of "practically all workmen working in 
and about said industries with one single exception - that is, the rollers." ${ }^{\text {,40 }}$ The second group was called themselves the Progressive Movement of the A. A. I. S. and T. W. Their goals were, among other things, industrial unionism and, specifically, the extension of referendums in the union. ${ }^{41}$ These attempts to create a new union were unable to gain momentum and failed.

According to historian David Brody, the Amalgamated Association would probably have held "small future importance" after their descent began if it did not have "legitimate jurisdiction" over all steelworkers under the AFL. According to its constitution, the Federation had to involve the Amalgamated Association in any effort to organize the steel industry. ${ }^{42}$ Certainly after 1901, and probably since the Homestead strike, the AAISTW needed the support of the AFL. While some in the Association had sought to make it more of an industrial union, the Amalgamated leaders had adhered to the principles of craft unionism, which fit nicely with the AFL's conservative ideology. Strangely, Samuel Gompers had been an early proponent of industrial unionism. In 1888, he had advocated that conventions based on industrial divisions, and that representatives from those conventions, should be sent to the AFL convention. Thus, all of the metal industry unions, for example, would meet and elect delegates to represent the workers from the entire industry. Under his plan, the AFL would have eventually become a collection of industrial unions, but this met with such sharp disapproval that Gompers dropped the plan and became the leading spokesman of craft unionism. ${ }^{43}$ In the years after that, the AAISTW had also rejected industrial unionism, and a bond formed between the two organizations that proved to be enduring.

By 1909, there were few in the Amalgamated Association that questioned its membership in the Federation, but they originally had a rocky relationship. Gompers later recalled that at the labor congress in Pittsburgh in 1881, as the Federation was coming into existence, one of the "most important men" there was John Jarrett, the president of the Association, "then the strongest trade union."44 At the conference, Jarrett insisted that a resolution calling for protective tariffs be adopted, and the following year in Cleveland when that resolution was repealed, Jarrett and the Amalgamated Association withdrew from the AFL. ${ }^{45}$ Furthermore, some of the AFL's most critical concerns were contradictory to that of the Amalgamated Association, the eight-hour day movement for example. Ironworkers were paid on a tonnage basis that was tied to the market price. The twelve-hour and five heat day were entrenched traditions among ironworkers, 
and many were suspicious of trying to change the length of the workday for that reason alone. Others feared that, once they changed to eight hours, they would not have the clout to get the increase in the wage scale that would be necessary to ensure them the daily wage that they had been receiving. ${ }^{46}$ Thus, initially the two organizations were at odds. Finally, the 1901 clash between T. J. Shaffer and Samuel Gompers led to animosity on a personal level.

In both 1901 and 1909, the Amalgamated presidents asked Gompers to do for their union what he had done for the miners' union in 1897. From the perspective of Shaffer and McArdle, the United Mine Workers of America was in dire straits at the beginning of 1897. During the miners' strike that year Gompers and the AFL became involved to such an extent as to both win the strike, securing better wages and consequently the eight hour day, and turn the UMWA into one of the strongest unions in the country. Gompers responded to both Shaffer and McArdle that the circumstances had been entirely different. Several coal operators supported the miners' strike which sought to bring uniform wages. Furthermore, most of the bituminous miners were on strike, and only a few specific regions had yet to stop mining. Thus, when the AFL organized a conference that was held in Wheeling on July 27, 1897, the participating union leaders only needed to focus organizing efforts on the minority of miners. Conversely, in 1901 and 1909 the majority of steelworkers did not belong to the union and were not on strike. They did not have the support of any of the companies. In fact, the various steel concerns around the country were hoping U. S. Steel would win so they too could push the open shop. In other words, the AFL would have had to take on a much broader fight to unionize the steel industry. ${ }^{47}$ Gompers responded in 1901 to Shaffer by contacting the National Civic Federation and working toward conciliation. In 1909, he did organize the December meeting at the Monongahela Hotel which was similar to the 1897 Wheeling meeting, and the national union leaders who came out of that meeting vowed to "completely organize all employees in the iron, steel and tin plate industry and subsidiary co-related trades." Unfortunately, Gompers was only able to enlist less than a dozen organizers willing to take on the task of organizing the steel industry. Neither action proved helpful for the Amalgamated Association.

Gompers grand scheme for defeating U. S. Steel did not focus on extensive organizing efforts anyway. He had been lobbying for an investigation of U. S. Steel on the basis that it violated the Sherman Anti-Trust Act. Originally, the AFL petitioned President Howard Taft, but 
Taft referred the whole matter to the U. S. Attorney General Wickersham. ${ }^{48}$ Congress did investigate and held hearings on U. S. Steel, but they merely told Elbert Gary that he could no longer set prices for the whole steel industry. Gompers, years later recalled that, in regards to organizing the steel industry in 1909:

My plan was to have a committee of representatives of those organizations immediately concerned and to accompany the work of organization with a demand upon the government to investigate the United States Steel Corporation. I did not believe in the Sherman Anti-Trust Law because I did not believe that legislation would prevent normal, necessary development of industry; but since the law was on the statute books and the practices of the steel corporation were in open and flagrant violation of that law and since the corporation denied to wage-earners the right of collective action which they arrogated to themselves, it seemed to me that the labor movement was in a strategic position to call attention to the situation. ${ }^{49}$

P. J. McArdle initially welcomed the assistance of the AFL, but was sorely disappointed, if not disgusted, with the pitiful assistance that finally arrived. After so much rhetoric and raised expectations, the handful of organizers and the plea to the federal government that Gompers made were hardly the kind of tactics for which McArdle had hoped. There were no sympathy strikes called, not enough funding to seriously advance the strike, and no extensive campaign to shift public opinion in the steelworkers' favor. Thus, while the AFL imposed upon the Amalgamated Association a strict trade union structure that hindered its progress, at critical times the support the Association needed did not arrive. Meanwhile, the steelworkers were left with a union that could not meet the challenges of organizing skilled and unskilled workers, and Americans and immigrants into the same union.

After the 1909-1910 strike the AFL and the Amalgamated Association made a concerted effort to organize the whole steel industry; not just the skilled divisions and not just the skilled workers. The labor aristocracy finally recognized that their narrow approach of the past could no longer be successful in the modern steel industry, and they sought to include every worker, even the unskilled immigrants. In 1910, McArdle wrote to Gompers, saying that immigrants had "largely displaced native born and other English men in labor." He informed Gompers that this was especially true where mechanical improvements had reduced the need for skill and continued to say that while immigrants were employed "as a fixed policy of the steel manufacturers after the Homestead Strike in 1892," that it had been "carried to a fuller fruition" by U. S. Steel. ${ }^{50}$ The 
American Federationist declared that so "wisely have the managers of the steel corporation planned to prevent co-operation of workers, that the assemblage in their mills is like the meeting of many nations - a most complete execution of their publicly declared policy in favor of foreign workers. This modern Tower of Babel breeds confusion and isolation of workers because of the separation arising because of many tongues." ${ }^{, 51}$ Truly, by the time of the 1909-1910 strike, immigrants held the majority of jobs in the large steel mills. For example, sixty percent of Carnegie Steel's employees were unskilled immigrants. ${ }^{52}$

In 1912, the AFL launched a new organizing drive. In August of that year a circular was issued declaring that the "time is at hand when the iron and steel workers, regardless of their mechanical ability, their creed, color, or nationality, should be bound together by a true spirit of fraternity and solidarity - features which are essential if you hope to abolish wrongs, attain rights, and improve conditions." It instructed workers that there would be two circulars to follow. The next would explain the aims of organized labor, the conditions under which the mill workers suffered presently, and what could be accomplished through organization. The third and final circular would designate a single day when all the mill workers in all the various towns could meet in order to organize. The reason all the meetings would take place on the same day was to "prevent discrimination." The circular concluded by telling immigrants to write their friends and family "across the water" and advise them not to come to America for a year or two. ${ }^{53}$ By as late as March, 1913, the first stage was, evidently, completed, and the American Federationist reported that organizers had been "quietly, persistently, and steadily" spreading the word of trade unionism in the steel mills. This time they targeted immigrants. "Organized labor, now as always," the article claimed, "is the one institution that aims and tends to convert foreign workmen into American citizens." Toward that end, the AFL's most recent circular was translated into twelve languages. ${ }^{54}$ Despite these efforts, the AFL had little success beyond intermittent and purely local revolts by the workers of U. S. Steel.

They were unable to reverse the momentum of the open shop drive. Simply deciding to include everyone could not undo the previous twenty years of backsliding. Organizing immigrants was only one of many obstacles that the AFL and the Amalgamated Association faced in organizing the work force. While immigrants held the majority in the mills, there were still thousands of Americans working the mills that two organizations failed to attract. The 
highly skilled workers, for example, were often promoted to foreman positions with a chance of moving into management. Many of these workers could not see the need for a union as they were content with their working conditions and wages. Their helpers in the rolling mills and other more skilled areas coveted the same promotions, hoping they too would ultimately make more money and work less strenuous jobs. ${ }^{55}$ The overall picture, however, was one of diminishing wages, longer hours, and increasingly worse working conditions. Consequently, many workers remained devoted to bettering their conditions, but U. S. Steel employed a variety of methods to safeguard its mills against the union.

AFL organizer J. D. Pierce, who worked in the Ohio Valley, outlined U. S. Steel's methods. U. S. Steel, he said, had an "effective Blacklist" that kept "their employes from expressing their true feelings." Employees would be put on the blacklist if they attended union meetings or promoted unionism among fellow workers. As Pierce explained that being put on the blacklist meant more than "interfering with men obtaining employment but reaches the landlord, the grocer and butcher who are told not to give credit to such employees on threat of incurring the displeasure of the corporation." The result of the blacklist was tremendous. Pierce said that it had "so broken the spirit of the men that they do not place confidence in each other dare not speak to each other for fear a word may be dropped that may reach the ear of the foreman." ${ }^{, 56}$ Pierce also charged that, to keep unions, U. S. Steel had "established their detective bureau and have a complete organization in every place where mill are located." The picture he presented was grim: "They have complete control of all borough officials from the lowest to the highest, ready and willing to do their bidding. Business men dare not oppose them through fear of the banks which they do business with. In fact they are thoroughly entrenched with a perfect organization and with unlimited money., ${ }^{, 57}$

Directly after the 1909-1910 strike in the Wheeling district, the U. S. Steel plants were restarted one by one. The LaBelle plant was the last of the three U. S. Steel tin plate plants in the district to restart, which it did in late February, $1911 .^{58}$ To some degree, the plants restarted with a new work force. The Ohio Valley Trades and Labor Assembly wrote to Samuel Gompers that since the 1909-1910 strike that it was "impossible for an old employee who took any interest in the strike to get a job, whilst they will not tell them out right that that is the cause, but there is no work for him." The Assembly agreed with Pierce that U. S. Steel's influence went beyond hiring 
and firing. They reported that the environment in Wheeling had turned distinctly against organized labor because U. S. Steel had "subsidized the press to such an extent that our daily papers have positively refused to print any labor news either from our Assembly nor from the Belmont Central Trades and Labor Assembly." Furthermore, "their activity in politics is such that they almost dictate the election of certain men.

The effect of U. S. Steel's influence was felt among Wheeling's steelworkers who, in May, 1914, arranged to have a union meeting and invited AFL organizer John L. Lewis to attend. However, Lewis reported that "owing to conditions down there, the meeting failed to materialize and my trip was fruitless." ${ }^{\prime 60}$ Many no longer believed that even the powerful AFL could help them fight the corporation. The problems facing the steelworkers seemed insurmountable. U. S. Steel, they believed, had influence among local businessmen, the local press, and the local, state, and federal government. It seemed that all the institutions of the nation had turned against them. Since they no longer had the protection of the AAISTW and the AFL seemed powerless, steelworkers sought solutions outside of their union. While they believed in the core principles of trade unionism -- that they needed protection from the companies and corporations that employed them and that collective action was the only way to get that protection -- many began to wonder whether unions could ever meet their needs.

Gompers and other strict trade unionists argued that the government had proven repeatedly that workers could not rely on legislation or the courts to protect them. Therefore, they must rely solely on their union and union contracts with employers for everything including benefits, relief, and security. This forced the union leaders into the uncomfortable position of opposing government reforms such as the minimum wage and maximum hours laws. This philosophy, called voluntarism, dominated the AFL and its affiliated unions after 1900. ${ }^{61}$ Llewellyn Lewis, who had been president of the Ohio Federation of Labor and a vice-president of the Amalgamated Association, believed that trade unionism was the only way for working people to better their lives. He asked: "When officials of a great corporation are permitted to lead mobs against honest citizens of other states or their own state; when the state is so rotten under the control of the money power; when in all the space between abject submission and rebellion no place is given for appeal, argument or protest, what is the remedy?" His answer was that if workers only added "a little courage" to their convictions that their trade union would flourish 
and carry them "to a place in life that will give you peace, prosperity and happiness." "62 However, as time and time again the Association and the AFL failed, even Lewis became disillusioned. Lewis resigned from the union blaming craft union approach of the Association and the AFL for the failure of the 1909 organizing drive in which he had been so involved. He parted saying that the AFL's "policies are antiquated and unfit for application to present day conditions. The policies of 25 years ago won't do for today. The world is moving and we must move onward with it or be left far behind.",63

Others believed that trade union membership was important, but also that government as it now stood could be changed to serve the needs of the working class. Matt Greer, president of Wheeling's Prosperity Lodge, wrote that the November 1909, labor parade through Wheeling was "an eye opener to the business men of Wheeling to see the host of labor all join in one common cause against the open shop." If only they could vote as they had marched, he reflected, then workers would not be asked to work in open shops or suffer government by injunction. When workers vote together then they "will have equal rights for all and special privileges for none, as guaranteed by the consititution." 64

An increasing number of workers disagreed, concluding that the government and the capitalist system that it promoted must be changed radically in order for it to serve the working class. The Socialist Party was a political organization that sought to effect such a change. While party members were certainly not discouraged from belonging to labor unions, Socialists believed that in order to achieve social justice, they must do it at the election booth. Two-time Socialist Party presidential nominee Eugene Debs, however, was opposed to conservative unions like the AFL and the Amalgamated Association claiming that companies allowed such unions to continue so as to prevent socialism from growing. "Why didn't the steel trust annihilate the Amalgamated Steelworkers?" he asked in a 1905 speech in Chicago. "The trust had its iron heel upon the neck of the Steelworks' Union, and could have, had it chosen, completely crushed the life out of it," but J. P. Morgan and Charles Schwab, he contended, "have discovered that a union can be turned the other way; that it can be made useful to them instead of being useful to the working class." The steel magnates came to favor trade unions "because they knew that another and a better one would spring from its ruins. They were perfectly willing that the old craft union should grow up again and block the way to real union."65 Gompers even used this logic in 
defense of the AFL arguing that if their "constructive and conservative labor movement" was "outlawed" that ultimately it would be replaced by "another movement not constructive and not conservative in character." ${ }^{, 66}$ In the words of one party leader, Morris Hilquit, Socialists sought "not only collective ownership, but also democratic administration of the industries" Just as Democracy meant political self-government, Socialism meant industrial self-government. Ultimately, they hoped that industry would resemble the American government, where representatives would be elected to run businesses and remain subject to the electorate. ${ }^{67}$

There was a strong Socialist element in the Amalgamated Association by the time of the 1909-1910 strike. W. H. Evans wrote that "at the ballot box on next election day is the only place the workingman can hold his own." As long as workingmen had to work for wages to purchase food and clothing as they did "under the present system of private ownership" that companies would be able to close down mills and dictate the price they would pay for that labor as well as the working conditions. He urged steelworkers: "Study up Socialism boys and see what they can do for you. You have tried the other side long enough.",68

Eugene V. Debs came to Wheeling in March 1910 and spoke to a full house at the Victoria theatre. He outlined the purpose of the Socialist Party saying that they hoped to restructure society and form the first industrial democracy that the world had ever seen. "Society has always been organized on a basis of exploitation of those who toil," he told the audience. "In ancient times, the ruling classes made slaves of the workingmen; in the middle ages, they made serfs of them and in modern time, they have made them wage workers." Socialism would finally change that, and workers would be the ones benefitting from their labor. ${ }^{69}$

The Socialist Party gained a great deal of support in the Wheeling district after the strike, beating the Republicans in some districts, but falling short of electing their candidates. "The Socialists of Wheeling, of the Ohio Valley and of West Virginia have joined the rest of the country in making an excellent showing in the elections just over," the Wheeling Majority declared after the November 1910 election. ${ }^{70}$ Over a year after the steel strike had ended, Debs returned to Wheeling on October 18, 1911, to speak at a high school auditorium. He commended the "valiant unionists" of the area "for the magnificent battle they put up against the Steel Trust." He did not spare the superlatives claiming that "no men anywhere ever made a better fight, and if they had fought everywhere as you fought here, the battle would have ended in a victory for the 
workers." Yet he told the listeners that they were ignorant and kept ignorant for the benefit of the ruling class. "That is why the old party politicians, in their speeches, call you intelligent, only to keep you ignorant. And that is why the Socialist tells you [that] you are ignorant, in order that you may become intelligent." He concluded: "You must organize and act industrially and politically. Organize politically, not through the expectation of rewarding your 'friends and punishing your enemies,' but in the class conscious Socialist party. Organize industrially, not in obsolete petty craft unions, but by industries where the combined weight of the workers in an industry can be brought to bear.,"71

Another group of Socialists believed that the government would never be changed to benefit workers by conventional methods. The Industrial Workers of the World (IWW) believed that when the workers were "fully organized and class conscious" they could seize industries at the "point of production" and administer them by and for the workers. Like the Socialist Party, the IWW believed that society would necessarily have to be restructured in order to get justice for the workers, but the IWW did not believe that workers would ever gain control of the workplace through union contracts or through political action. Instead, they believed that only through revolutionary action would the workers ever achieve an industrial democracy. ${ }^{72}$

During the 1909-1910 strike, the Industrial Workers of the World (IWW) set up a relief station in New Castle that was open to all strikers. This was greatly appreciated, especially by the immigrants who were not members of the Amalgamated Association and, therefore, not eligible for strike relief. ${ }^{73}$ In other locations, like Wheeling, immigrants drifted to other jobs or assisted the company in reopening the plants. In New Castle, the IWW assistance given to and the organization of the unskilled workers made it possible to keep all the workers in line and firmly set against the company. ${ }^{74}$ At the same time, the IWW won a victory for immigrant workers in a plant of the Pressed Steel Car Company in McKees Rocks. Traditional union wisdom had held that immigrants made poor union men, but the IWW was having tremendous success in organizing these workers. ${ }^{75}$

Publicly, P. J. McArdle supported the IWW saying that the Amalgamated Association would "maintain a faithful alliance with the Tin Workers Association and the I.W.W. until a conclusion has been reached and an agreement signed with all three organizations." ${ }^{, 76}$ The alliance in New Castle, however, was isolated and temporary. Privately, McArdle admitted to 
Frank Morrison of the AFL that he was worried: "There is no question but that more and more of the foreign-born workers in the industry are becoming impressed by the vision held out by the Industrial Unionists, and the victory at McKees Rocks has given them a strong talking point so much so, in fact, that even our members are beginning to pay attention to what they say. While it was necessary for us to cooperate with them at New Castle, we certainly do not look forward to the prospect of their growing influence among the iron, steel, and tin workers." There was no reason to "bewail these unfortunate developments," but the AFL had to prove itself "capable of winning the strike against the American Sheet and Tin Plate Company and move to organize all the non-union mills in the industry." Otherwise, McArdle implied, the Association and the Federation would soon see their members desert to organizations that were having success in the steel industry. ${ }^{77}$

The IWW's influence would be felt in the Wheeling district not long after the 1909-1910 strike. Independents were beginning to rival U. S. Steel in their opposition to organized labor. During the 1909-1910 strike the Phillips Sheet and Tin Plate Company of Clarksburg, West Virginia, moved into the Wheeling district and would ultimately enormous impact on the region. The man behind the new venture was E. T. Weir, for whom the town of Weirton and Weirton Steel were named. Weirton Steel ultimately grew to become West Virginia's single largest employer.

Weir had been the superintendent at the Monessen plant of U. S. Steel where they used the two-roll system of making tin plate that was so disliked by the workers. In 1904, they were the first to use open-hearth steel on the two-roll or two mill system. It had not previously been thought "practical" because of the "great care" required in the rolling process. Weir said that "the fact that the men employed at the Monessen mill have successfully worked the open-hearth steel on the two mill systems goes to show that they are as skilled in the rolling of tin-plate as any workmen in the world." ${ }^{, 78}$ In May 1909, the Phillips company broke ground for the new tin plate plant. ${ }^{79}$ Weir cited two reasons for locating the plant on the Ohio River across from Steubenville: river access to cheap raw materials and close proximity to the most skilled workers in the industry. "We get the better class of workmen here because the best labor will not leave the Pittsburgh district. They have been here for generations and refuse to change. For this reason we elected Weirton for the new plant which will start with eight hot mills and a tin house." ${ }^{\prime \prime}$ In 
late October, 1909, Weir, now president of the Phillips company, began networking at the Waldorf-Astoria hotel in New York, now a member of the steel elite. ${ }^{81}$ In December, the company announced that there were 1,000 openings for workmen at the new plant, and striking workers from the U. S. Steel plant applied for the jobs. ${ }^{82}$ The mill began operations in February, 1910, and in April, hundreds of new houses were being built by the Phillips company in Weirton. ${ }^{83}$ Thus, in less than a year, Weir and the company had become a force in the Wheeling district.

The Phillips Sheet and Tin Plate Company purchased the Pope Mill in Steubenville, and in 1913, the tin house workers in Wheeling and Follansbee, employed by other independent companies, decided to push for the organization of the Steubenville plant. The Industrial Workers of the World were agitating in the area, and the Socialists of the AFL affiliated Ohio Valley Trades and Labor Assembly feeling threatened by the rival organization decided to push for organization on a federated craft basis that included unskilled workers at the Steubenville plant. ${ }^{84}$

W. S. Hunt, now president of the TPWIPA, wrote to Samuel Gompers on June 6, 1913, asking if Gompers could "help us in any manner as regards Weirton. Of course we intend to strike if the scale is not signed." ${ }^{~} 85$ The AFL sent general organizers to Steubenville to assist Amalgamated Association organizers. They tried to go to Weirton to organize, but John L. Lewis reported that Weirton was a small town that was "practically owned by the steel companies" and the organizers were forced to leave town "by the agents of the steel corporation." ${ }^{86}$ The Amalgamated Association held a meeting on June 30 and called a strike. Lewis addressed the strikers in Steubenville on July 10, reporting to Secretary Morrison: "We have been lending this assistance to the Amalgamated Association at the request of President [John] Williams of that organization, and I feel that in the matter of taking care of the foreign element in the strike at last, we have been able to do them some material good." He estimated that the company had imported between 300 and 400 strike breakers, half of whom were acting as armed guards on company property, but because Steubenville's city administration was friendly to labor, the guards were not allowed to walk the streets. In all, Lewis felt that the strike was progressing nicely without desertions and that the prospects were "very good." 87 
Hunt went to Steubenville to inspect the situation himself. He wrote to Morrison: "I have been on the firing line at the mill in Steubenville, Ohio for the past three weeks. I met your organizers from Pittsburg all of which were put out of Wierton [sic] by hirelings of the Phillip [sic] Sheet \& Tin Plate Co." But the strike had nearly exhausted the TPWIPA's treasury. Hunt contacted the Amalgamated Association to see if the Association was interested in combining, and the two organizations agreed on terms. While Hunt was certain that the unification would be approved, in the meantime the union needed several hundred dollars to holds its annual conference. After the forthcoming combination, the Amalgamated Association would obviously fund them the rest of the way. ${ }^{88}$ Morrison wrote to AAISTW President Williams that the AFL was "in no position to appropriate money as per the request of President Hunt" until the AFL's Executive Council approved the measure, which he doubted that they would do. He, therefore, asked the Amalgamated Association to fund the TPWIPA until they combined. ${ }^{89}$

Agitation to merge the two unions had begun towards the end of the 1909-1910 strike. In fact, some believed that it would happen at the 1910 conventions of the two unions. The AFL had recommended that the AAISTW and the TPWIPA merge, and President McArdle concurred. Then the old craft union rivalries cropped. ${ }^{90}$ The TPWIPA thought the two organizations should merge into a new union with a new name as there was still resentment against the Amalgamated Association for not permitting the tin house workers into their union in the first place. " "They should never have been apart," the Wheeling Majority declared. "But in the old days of the Amalgamated they only thought of protecting the high waged skilled men, and did not foresee that changing industrial conditions, with the ever increasing field of machinery, would make ever less and less small the field of the purely skilled and make the unskilled man the one with whom to deal." The editorial urged the two unions to find a way to create a union that would ensure that no one division of workers would be favored over another. ${ }^{92}$ The merger failed to materialize in 1910, however, and the two union were still discussing it by the time of the 1913 Steubenville strike. The AA and TPWIPA finally merged on June 30, 1913, but by this time the TPWIPA only numbered 500 members. ${ }^{93}$

To what degree the various organizations, the AA, the TPWIPA, the AFL, the socialists of the OVTLA, and the IWW, participated in the strike is unclear. What is certain is that the strike was very violent. Company guards and strike breakers fired rifles in the direction of mill 
workers' homes, and gunmen shot several strike leaders from a moving automobile. Ultimately the strike was lost. ${ }^{94}$

The IWW continued to agitate among workers in the area. Joseph Ettor preached the "doctrine of the general strike" to striking coal miners in Bellaire, Ohio, in June, 1914. He said that it was the shortest way to revolution, the goal of all Socialists, but that the Wheeling Socialists would never accomplish anything. They had too great an interest in the status quo, he argued, as their craft unions were in a favorable position in the present system. All they would ever do, he said, was pass decorous resolutions. ${ }^{95}$ Ettor and other IWW agitators met with some success among the miners, and kept a close watch on local tin plate industry from Weirton down to Wheeling, including the recently built tin plate plant at Yorkville, Ohio. "The tin plate industry," they reported, "appears to be in excellent shape, from the standpoint of operation, but mill owners continue to complain of lack of profits, and to prophesy evil results from ruinous competition with the Welsh manufacturers.",96

Evidently, the IWW had some success with the local steelworkers as a "disruptionist movement" was started in 1915 in Wheeling by "certain malcontents," according to John Williams, that advocated industrial unionism and even associating with the IWW. Williams forbade members from joining the IWW on the grounds that it was a "dual union," one that trespassed on the AAISTW's jurisdiction. He assured members that the Amalgamated Association would "never become the tail of a kite to any seceding organization, particularly one of the character of the I. W. W."97 As Williams had wished, the movement failed to gain momentum. 


\section{Epilogue}

With the start of World War I came a whole new set of circumstances. As the flow of immigrants into the United States was seriously stemmed, companies had to deal with a fixed labor pool. ${ }^{1}$ Furthermore, as demand increased to meet wartime production, labor was more in demand. Workers in the steel industry, sensing their position of increased power, rebelled against their working conditions. The federal government under Woodrow Wilson intervened to ensure continued production for the war effort. In March 1918, the National War Labor Board was created to mediate between labor and capital with the principles that employers must recognize the right of workers to organize into trade unions and that unions must recognize the right of workers to remain non-union. With the implied threat that the government could nationalize the steel industry, Felix Frankfurter, the secretary of the War Labor Policies Board, was able to coerce men such as Elbert Gary into accepting the eight-hour work day as a standard and paying time-and-a-half for overtime. ${ }^{2}$

The result of these concessions and the existence of a federal board recognizing the right to organize revived the Amalgamated Association. The National Committee for Organizing Iron and Steel Workers was created in 1918 with three AFL men in charge: John Fitzpatrick, president of the Chicago Federation of Labor; William Z. Foster, an organizer for the AFL who had once been in the IWW and had radical tendencies; and Samuel Gompers, still president of the AFL. The Amalgamated Association recognized that they were in no position to demand all the benefits of the new organizing drive and allowed other unions jurisdiction over many of the steelworkers, such as the machinists, boilermakers, and electrical workers. ${ }^{3}$ After a tremendously successful drive, which began in Johnstown, Youngstown, and Wheeling, ${ }^{4}$ the industry remained only partly organized, and the war came to an end. Employers began to refuse to recognize unions and to revoke concessions made during the war. Furthermore, Employee Representation Plans (ERPs) were inaugurated by companies in an attempt to circumvent legitimate unions. Tensions built to the point where a strike had to be called despite the fact that the union was not fully prepared. On September 22, 1919, after much debate among union leaders, a strike was

called, and about 250,000 workers stopped work, roughly half the industry. ${ }^{5}$ No longer hindered by the federal government, companies employed the same tactics to break the strike that had proven so effective in the past. By September 30, 1919, 15,000 were on strike in Wheeling 
alone. ${ }^{6}$ Biased newspaper coverage, strikebreakers, and the Pennsylvania State Police went a long way toward bringing the struggle to an end. The strike's failure left many wondering if the steel industry would ever be unionized again.

In 1920, the Wheeling Steel Corporation was formed, bringing together nearly all the independent mills that remained in the Wheeling district, Weirton Steel being a notable exception. In June 1921, the 1909-1910 strike was replayed on a smaller scale in the Wheeling District. The Amalgamated Association asked Wheeling Steel's president, Isaac M. Scott, to sign a wage scale for all the plants. He offered to sign for the plants already covered, meaning the Whitaker-Glessner plants and Yorkville's big tin-plate mill. On June 30, when the scale expired the Amalgamated called a strike and Wheeling Steel's unionized mills were shut down. In February, with increased demand, Scott offered to take the union men back but continued to refuse to sign a contract for all the plants. The union workers refused his offer, and non-union men were brought in to start the mill up again, effectively ending unionism in the Wheeling district for another twenty years. ${ }^{7}$

U. S. Steel's prominence in the Wheeling district waned after the 1909-1910 strike. Historian Henry Scott wrote that the "acute disturbances in the Wheeling district," particularly the strikes of 1901 and 1909, had a "disastrous effect on the attitude of the Steel Corporation toward this community." By 1928, the Aetna-Standard, once one of the "vital units" of U. S. Steel had been dismantled until only two jobbing mills remained, and the LaBelle tin mills had been torn down. Other mills were shut down, and orders were directed to other towns. By the 1930s, only the Laughlin plant remained active among local U. S. Steel tin plate plants. Scott argued that with "the whole United States from which to choose, the big Corporation could hardly be expected to foster the development of any recalcitrant district." ${ }^{8}$

In 1933, Congress passed the National Industrial Recovery Act (NIRA) as a part of Franklin Roosevelt's New Deal. Section 7a of the Act formally recognized for the first time in federal legislation the right of workers to organize. Strikes broke out almost spontaneously in response. Workers at Weirton Steel walked out in 1933 in an effort to gain union recognition, but E. T. Weir was able to use the existing ERP, as well as coercion and intimidation, to defeat the effort. ${ }^{9}$ The National Labor Relations Act of 1935, also known as the Wagner Act, reinforced section $7 \mathrm{a}$ of the NIRA, and new organization efforts were initiated. The Wagner Act created the 
National Labor Relations Board (NLRB) whose purpose was to govern industrial relations ensuring that workers' rights were not violated by companies. It has been called the workers' bill of rights. In 1937, John L. Lewis and Philip Murray created the Steel Workers Organizing Committee (SWOC), and unionization of the steel industry began in earnest.

That year, Myron Taylor of U. S. Steel and Lewis held a series of private meetings that resulted in the recognition of collective bargaining rights among U. S. Steel employees. Taylor was not forced to recognize any union by law as the Supreme Court was still determining the constitutionality of the Wagner Act, but he probably did it for a variety of reasons. It is likely that he sought labor stability as the corporation began to emerge from the Great Depression. Additionally he was no doubt aware that workers were disillusioned with corporate welfare, a result of the recent hard times when unemployment could not be avoided. Also, the atmosphere of the late 1930s was very different, and the tactics that worked in 1892, 1901, 1909, and 1919, probably would not work with the federal government supporting workers' rights. Finally, Taylor and Lewis developed an affinity for one another, and their mutual respect might have swayed Taylor. Whatever the reason, U. S. Steel had bowed to the recently formed SWOC, recognizing it as a bargaining agent. ${ }^{10}$

While U. S. Steel recognized the workers fairly quickly, the real fight of the SWOC was in "Little Steel." In 1943 and 1944, Weirton Steel again stymied unionization of its mills by discharge and intimidation, firing over 100 workers on each occasion. ${ }^{11}$ The Wheeling Steel Corporation was finally forced to give into the SWOC and the NLRB in 1942 after having remained non-union since the 1921 strike. 


\section{Conclusion}

Wheeling's iron and steel industry developed slowly over the entire 19th century. When confronted by competition from the wire nail, local businessmen adjusted and converted their mills to tin plate production. With the series of mergers at the end of that century, managers no longer had the option to be flexible. Instead, orders came from the corporate offices of U. S. Steel, and executives there had no loyalty to Wheeling or to Wheeling's plants. Likewise, labor policies were dictated by the executive committee. While there had always been struggles between management and labor in Wheeling, local workers and managers alike were now only actors on a national stage. The culmination of this was the 1909-1910 strike. Despite having remained strongly unionized in their district, Wheeling area steelworkers could no longer win strikes through local solidarity. The politics of the national labor organizations and the corporations had become more significant in determining the outcome of such struggles. Recognizing this, workers sought solidarity on a national level by trying to change their trade union into an industrial union. When that failed, even their local solidarity was broken as many joined rival organizations or abandoned the labor movement altogether looking to politics to bring change. With the labor movement fractured, the local, independent steel companies found it easier to drive the unions from their mills. The result was an era that lasted from World War I until 1937 when steelworkers had no control over their working conditions. 


\section{Endnotes}

\section{Introduction}

1. Notice reprinted in Wheeling Daily Intelligencer, June 2, 1909, and John Fitch, The Steel Workers (Pittsburgh: Russell Sage Foundation, 1910). For ease of reading, all instances where "employe" or "employes" appeared in contemporary sources, I have changed it to employee and employees.

2. David Brody, Steelworkers in America: The Non-Union Era (New York: Harper \& Row, 1969); John Garraty, “The U. S. Steel Corporation versus Labor: The Early Years," Labor History 1 (1960): 3-38.

3. Brody, Steelworkers, 50-51

4. Fitch, 89.

5. Brody, Labor in Crisis: The Steel Strike of 1919 (Philadelphia: Lippincott, 1965), 2627.

6. Philip Foner, History of the Labor Movement in the United States. Vol. III: The Policies and Practices of the American Federation of Labor, 1900-1909 (New York: International Publishers, 1964). See chapter 2, "The Open Shop Drive," 32-60.

\section{Chapter One: Rise of the Tin Plate Industry in the Wheeling District}

1. Amos J. Loveday, Jr., The Rise and Decline of the American Cut Nail Industry: A Study of the Interrelationships of Technology, Business Organization, and Management Techniques (Westport, CT: Greenwood Press, 1983), 37.

2. Loveday, 47.

3. H. D. Scott, Iron and Steel in Wheeling, (Toledo, OH: Caslon Co., 1929), 40.

4. Scott, 40-46.

5. Scott, 55 .

6. Loveday, 101, qtd. from Wheeling Intelligencer, June 30, 1880.

7. Scott, 55.

8. Loveday, 105.

9. Scott, 65-68.

10. Peter Temin, Iron and Steel in Nineteenth-Century America: An Economic Inquiry (Cambridge, Mass: MIT Press, 1964), 125-26.

11. Earl Chapin May, "The Nailers Strike Themselves Out!" chapter 25 in Principio to Wheeling, 1715-1945: A Pageant of Iron and Steel (New York: Harper \& Brothers, 1945), $182-$ 191. 
12. Loveday, 116, 140-41.

13. Donald Dunbar, The Tin-Plate Industry: A Comparative Study 4, 16.

14. U. S. Bureau of the Census, Twelfth Census of the United States of America (1900) Vol. 10, Manufacturing, pt. 4, "Tin and Terne Plate," (Washington: Government Printing Office, 1901), 112-13.

15. Loveday, 140-41.

16. Dunbar, 1.

17. Dunbar, 6.

18. Dunbar, 6-7.

19. Dunbar, 6-7.

20. Dunbar, 8-10.

21. Dunbar, 8-10.

22. Dunbar, 10-11; For descriptions of the process, also see "Manufacture of Tin Plate," Scientific American 87 (November 1, 1902): 290; Stewart, William R. "Great Industries of the United States: Part IV, Tin and Terne Plate," Cosmopolitan 37 (October 1904): 639-50.

23. Twelfth Census, 101.

24. Dunbar, 11.

25. Brody, Steelworkers, 31.

26. Twelfth Census, 109-14.

27. W. C. Cronemeyer, "The Development of the Tin-Plate Industry," Western Pennsylvania Historical Magazine 13 (January 1930), 28.

28. Cronemeyer, 31.

29. Twelfth Census, 112-13.

30. Cronemeyer, 32-35.

31. Twelfth Census, 103-14.

32. Dunbar, 16.

33. Brody, Steelworkers, 1.

34. Scott, 110-13.

35. Scott, 114, 128-29; May, 200-202.

36. Scott, 120-22.

37. Scott, 114; Twelfth Census, 116-17; May, 201.

38. Scott, 127.

39. Scott, 128-29; Twelfth Census, 117. 
40. Twelfth Census, 116-17.

41. Scott, 127.

42. Scott, 129.

43. Twelfth Census, 114-116.

44. U. S. Commissioner of Corporations, Report on the Steel Industry, (Washington: Government Printing Office, 1911-1913), 1:1-8; Dunbar, 74-85; Cronemeyer, 128-35.

45. Dunbar, 75.

46. Dunbar, 75.

47. Cronemeyer, 128.

48. U. S. Industrial Commission, Reports, (Washington: Government Printing Office, 1899-1901), 1:855.

49. Industrial Commission, 1:866.

50. U. S. Commissioner of Corporations, 1:3; Twelfth Census, 118.

51. U. S. Commissioner of Corporations, 1:5-6.

52. Cronemeyer, 133; Dunbar, 79; Cronemeyer lists them all and says 40 and 279 while Dunbar says 39 and 289.

53. Twelfth Census, 118.

54. U. S. Industrial Commission, 1:858.

55. Scott, 145.

56. Scott, 137.

57. Twelfth Census, 110.

58. Twelfth Census, 118; Wales produced 9,500,000 boxes that year or about 1 billion pounds.

59. Scott, 144.

60. Scott, 121.

61. U. S. Commissioner of Corporations, 1:3.

62. U. S. Commissioner of Corporations, 1:xvii.

63. Harold C. Livesay, Andrew Carnegie and the Rise of Big Business (Boston: Little, Brown, and Company, 1975), 182-88.

64. U. S. Commissioner of Corporations, 1:13.

65. Scott, 143. 


\section{Chapter Two: The Decline of the Amalgamated Association of Iron, Steel, and Tin Workers}

1. Amos J. Loveday, Jr., The Rise and Decline of the American Cut Nail Industry: A Study of the Interrelationships of Technology, Business Organization, and Management Techniques (Westport, CT: Greenwood Press, 1983), 104.

2. Quoted in Jesse S. Robinson, The Amalgamated Association of Iron, Steel, and Tin Workers, (Johns Hopkins University Studies in Historical and Political Science, Series XXXVIII, No. 2, Baltimore, 1920), 145.

3. Paul Krause, Battle for Homestead, 1880-1892: Politics, Culture, and Steel, (Pittsburgh and London: University of Pittsburgh Press, 1992), 111-112.

4. Krause, 103.

5. David Brody, Steelworkers in America: The Non-Union Era (New York: Harper \& Row, 1969), 50-51.

6. J. Stephens Jeans, ed. American Industrial Conditions and Competition. Report of Commissioners appointed by British Iron Trade Assoc. (London, 1902), 561 quoted in Brody, 32.

7. Krause, 145.

8. Edward W. Bemis, “The Homestead Strike,” Journal of Political Economy 11 (June, 1894), 375 quoted in Brody, 51.

9. John Fitch, The Steel Workers (Pittsburgh: Russell Sage Foundation, 1910), 91.

10. H. D. Scott, Iron and Steel in Wheeling, (Toledo, OH: Caslon Co., 1929), 87-88.

11. Fitch, 48.

12. Brody, Steelworkers, 58.

13. Fitch, 89.

14. Fitch, 132-133.

15. Brody, Steelworkers, 2-7.

16. Fitch, 115.

17. Brody, Steelworkers.

18. David Montgomery, The Fall of the House of Labor: The Workplace, the State, and American Labor Activism, 1865-1925 (New York: Cambridge University Press, 1987), 19.

19. Fitch, 102-103.

20. Fitch, 205.

21. Fitch, 124.

22. Harold C. Livesay, Andrew Carnegie and the Rise of Big Business (Boston: Little, Brown, and Company, 1975), 131-144; Melvin Dubofsky, Industrialism and the American Worker, 1865-1920, 2nd Ed. (Arlington Heights, IL: Harlan Davidson, Inc., 1985), 48-49. 
23. Brody, 119.

24. Fitch, 133.

25. U. S. Bureau of the Census, Twelfth Census of the United States of America (1900) vol. 10, Manufacturing, pt. 4, "Tin and Terne Plate," (Washington D. C.: Government Printing Office, 1901), 119.

26. U. S. Congress, Senate, Report on the Conditions of Employment in the Iron and Steel Industry, 62d Cong., 1st sess. (Washington, D. C.: Government Printing Office, 1913), 3:516.

27. Conditions, 3:516-518.

28. Conditions, 3:519-522.

29. Cronemeyer, 119; Fitch, 56.

30. Donald E. Dunbar, The Tin-Plate Industry: A Comparative Study of Its Growth in the United States and in Waels, (Boston and New York: Houghton Mifflin Company, 1915), 31-33.

31. Conditions, 3:516.

32. U. S. Industrial Commission, Reports, (Washington, D. C.: Government Printing Office, 1899-1901), 1:916-917.

33. Dunbar, 53.

34. Conditions, 3:181.

35. Conditions, 3:184.

36. U. S. Industrial Commission, 1:879.

37. Brody, Steelworkers, 60-61.

38. U. S. Industrial Commission, 1:869.

39. Dunbar, 10-11.

40. Dunbar, 44-45.

41. Elizabeth Beardsley Butler, Women and the Trades: Pittsburgh, 1907-1908, of Pittsburgh Survey, ed. Paul Kellogg (Russell Sage Foundation: New York, 1909), 227-228

42. Proceeding of the Second Annual Convention of the Tin Plate Workers' Protective Association of America (1900) 5-6. Hereafter cited as Proceeding TPWIPA (1900).

43. Constitution and General Laws of the Tin Plate Workers' International Protective Association of America (1901), 3.

44. Brody, Steelworkers, 60; Robinson, 45-46.

45. Consitution, By-Laws, and Rules of Order of the National and Subordinate Lodges of the Amalgamated Association of Iron and Steel Workers of the United States, 1876.

46. Consitution, By-Laws, and Rules of Order of the National and Subordinate Lodges of the Amalgamated Association of Iron, Steel and Tin Workers of the United States, 1877. 
47. Consitution, By-Laws, and Rules of Order of the National and Subordinate Lodges of the Amalgamated Association of Iron and Steel Workers of the United States, 1879.

48. Consitution and General Laws of the National A. A. I. and S. W. of the United States, 1889.

49. Charles E. Lawyer, "History of the Trade Unions: Tin Plate Workers," American Federationist 10 (September 1903), 841.

50. Proceeding TPWIPA (1900), 6.

51. Proceeding TPWIPA (1900), 7.

52. Proceeding TPWIPA (1900), 6.

53. Proceeding TPWIPA (1900), 12.

54. Lawyer, 841.

55. U. S. Industrial Commission, 1:904-906.

56. See Table 3 in Department of Commerce and Labor, Organization, Investment, Profits, and Position of the United States Steel Corporation, vol. 1 of Report of the Commissioner of Corporations on the Steel Industry (Washington: Government Printing Ofiice, 1911).

57. John Garraty, "The U. S. Steel Corporation versus Labor: The Early Years," Labor History 1 (1960), 8.

58. Scott, 152; Fitch, 134; Brody, Steelworkers, 61; Garraty, 8.

59. Proceeding TPWIPA (1900), 4.

60. American Federationist (September, 1899), 176.

61. "Wheeling and Vicinity," National Labor Tribune, May 16, 1901.

62. National Labor Tribune, May 23, 1901.

63. Garraty, 3, 6-7.

64. Brody, Steelworkers, 62.

65. Brody, Steelworkers, 62.

66. Conditions, 3:497.

67. Conditions, 3:497.

68. Conditions, 3:497-506; Also see Brody, Steelworkers, 62.

69. Fitch, 133.

70. The Nation 73 (August 15, 1901), 124 quoted from John Benjamin Moore, "Collective Bargaining in the Iron and Steel Industry, 1876-1910" (M. A. Thesis, University of Missouri, 1939), 114n.

71. Moore, 115. 
72. Brody, Steelworkers, 61.

73. Moore, 115-116.

74. National Labor Tribune, July 4, 1901.

75. Moore, 118.

76. Moore, 117.

77. Conditions, 3:501-506; Also see Brody, 63.

78. National Labor Tribune, July 11, 1901.

79. Garraty, 6.

80. Fitch, 214-220.

81. Conditions, 3:497-498.

82. Brody, Labor in Crisis: The Steel Strike of 1919 (Philadelphia: Lippincott, 1965), 26; Garraty, 6.

83. Conditions, 3:505.

84. Brody, Steelworkers, 64; Moore, 119; Fitch, 133.

85. “The Strike on in Full," National Labor Tribune, July 18, 1901.

86. "The Strike on in Full," National Labor Tribune, July 18, 1901.

87. Brody, Steelworkers, 64.

88. Brody, Steelworkers, 65; American Federationist (October 1901), 428.

89. Brody, Steelworkers, 65.

90. Brody, Steelworkers, 134n.

91. National Labor Tribune, August 1, 8, 1901 quoted in Brody, 66.

92. National Labor Tribune, August 29, 1901; Brody, 66.

93. National Labor Tribune, July 11, 1901.

94. Brody, Steelworkers, 122.

95. "Ovations at Wheeling," National Labor Tribune, August 22, 1901.

96. National Labor Tribune, September 19, 1901.

97. National Labor Tribune, August 15, 1901.

98. Scott, 152.

99. The Nation, 73 (August 15, 1901) 124.

100. Brody, Steelworkers, 66; Fitch, 135.

101. “Non-Union Deputies," National Labor Tribune, August 22, 1901. 
102. Marguerite Green, The National Civic Federation and the American Labor Movement, 1900-1925 (Ph. D. Diss., Catholic University of America, 1956), 25-36, gives a description of the strike focusing mainly on the NCF's role.

103. American Federationist, October 1901, 424.

104. American Federationist, October 1901, 415-417.

105. American Federationist, October 1901, 417- 431; "Settlement Circular," National Labor Tribune, September 26, 1901.

106. Brody, Steelworkers, 68.

107. Brody, Steelworkers, 67.

108. Robinson, 162.

109. Brody, Steelworkers, 67.

110. Moore, 124-125.

111. Moore, 110.

112. Fitch, 118, 229n.

113. Fitch, 229n.

114. Fitch, 218.

115. Fitch, 20.

116. William Z. Foster, The Great Steel Strike and Its Lessons (New York: B. W. Huebsch, Inc., 1920), 12; Horace B. Davis, Labor and Steel (New York: International Publishers, 1933), 230.

117. Brody, Steelworkers, 69.

118. National Labor Tribune, September 19, 26, 1901.

119. Brody, Steelworkers, 69.

120. Michael Santos, "Between Hegemony and Autonomy: The Skilled Iron Workers' Search For Identity, 1900-1930," Labor History 35 (Summer 1994) 399-423.

121. Walter Larkins to Samuel Gompers, October 28, 1908, AFL National and International Union Correspondence and Jurisdictional Dispute Records, Amalgamated Association of Iron, Steel, and Tin Workers File, Reel 38-6. Hereafter cited as AFL-AA.

122. Brody, Steelworkers, 153.

123. Foner, 4:281.

124. "Manufacture of Tin Plate," Scientific American 87 (November 1, 1902): 290.

125. Robinson, 20.

126. Amalgamated Journal, February 11, 1909.

127. Amalgamated Journal, February 25, 1909. 


\section{Chapter Three: The 1909-1910 Strike}

1. Wheeling Intelligencer, May 20, 1909.

2. See Horace B. Davis, Labor and Steel (New York: International Publishers, 1933), 231 , for a brief description of the strike.

3. U. S. Commissioner of Corporations, Report on the Steel Industry, (Washington, D. C.: Government Printing Office, 1911-1913), 1:xxiii, 57, 371-72.

4. David Brody, Steelworkers in America: The Non-Union Era (New York: Harper \& Row, 1969), 16-17.

5. Wheeling Intelligencer, June 2, 1909.

6. Wheeling Intelligencer, November 23, December 1, 1909, and May 24, 1910.

7. Wheeling Intelligencer, June 5, 1909.

8. Amalgamated Journal, June 24, 1909.

9. Wheeling Intelligencer, June 7, 8, 1909.

10. Amalgamated Journal, June 17, 1909.

11. Amalgamated Journal, June 24, 1909.

12. Amalgamated Journal, June 24, 1909.

13. "Strike Against the Steel Trust," AFL National and International Union Correspondence and Jurisdictional Dispute Records, Amalgamated Association of Iron, Steel, and Tin Workers File, Reel 38-6. Hereafter cited as AFL-AA.

14. New York Times, July 1, 1909; Wheeling Intelligencer, June 30, 1909.

15. Wheeling Intelligencer, July 2, 1909.

16. "Strike Against the Steel Trust," AFL-AA.

17. Wheeling Intelligencer, July 28, 1909.

18. Wheeling Intelligencer, July 5, 1909.

19. AFL, Proceedings (1909) 203.

20. National Labor Tribune, July 8, 1909.

21. Amalgamated Journal, July 1, 1909.

22. Iron Trade Review, July 15, 1909.

23. Philip Foner, History of the Labor Movement in the United States, 4:301.

24. Iron Age, July 8, 1909; National Labor Tribune, July 1, 1909; Wheeling Intelligencer, June 30, 1909. 
25. National Labor Tribune, July 22, 1909; Also see Brody, Steelworkers, 126.

26. National Labor Tribune, 1901 and Anne E. Mosher, "Something Better than the Best': Industrial Restructuring, George McMurty and the Creation of the Model Industrial Town of Vandergrift, Pennsylvania, 1883-1901," Annals of the Association of American Geographers 85 (1995).

27. Wheeling Majority, May 11, 1911, says that Llewellyn Lewis was the brother of Tom L. Lewis of the UMW.

28. Andrew Roy, A History of the Coal Miners in the United States From the Development of the Mines to the Close of the Anthracite Strike of 1902 (Columbus, OH: J. L. Trauger, c1902), 381-83.

29. The Ohio Historical Society has Llewellyn's 1903 diary from when he was an organizer, but I did not have an opportunity to examine it.

30. U. S. Congress, Senate, Report on the Conditions of Employment in the Iron and Steel Industry, 62d Cong., 1st sess. (Washington, D. C.: Government Printing Office, 1913) Vol. 3. Working Conditions and the Relations of Employers and Employees, Appendix E, 507; also see U. S. Congress. Sentate. Investigation of the Strike in the Steel Industries Hearings Before the Committee on Education and Labor. 66th Cong., 1st sess., 1919 (Washington: Government Printing Office, 1919), 3:124-25.

31. Conditions, 3:507; Investigation of the Strike (1919), 124-25; also see Amalgamated Journal, July 15, 1909.

32. Conditions, 3:508; Investigation of the Strike (1919), 124-25.

33. Amalgamated Journal, August 12, 1909.

34. Wheeling Intelligencer, August 6, 1909.

35. Conditions, 3:508; Investigation of the Strike (1919), 124-25; also see Amalgamated Journal, August 5, 1909.

36. Mosher, 84-107.

37. Mosher, 90.

38. Mosher, 84-90.

39. Mosher, 91-97.

40. Mosher, 99.

41. Mosher, 99-100.

42. Mosher, 101.

43. Mosher, 101.

44. National Labor Tribune, July 11, 1901.

45. Mosher, 101.

46. Mosher, 102. 
47. Mosher 84, 102.

48. Wheeling Intelligencer, August 6, 1909.

49. Wheeling Intelligencer, September 3, 1909.

50. Conditions, 3:509.

51. Wheeling Intelligencer, September 6, 1909.

52. Wheeling Intelligencer, September 6, 1909.

53. See George Williams, "The Professional Strike Breaker," Wheeling Majority Jan 13, 20, 27, Feb 3, 10, 17, 24, Mar 3, 10, 1910.

54. Depositions in American Sheet \& Tin Plate Co. v. Frank Bowman, et. al. July 1909, 132.

55. Depositions, 183.

56. Depositions, 183-89.

57. Depositions, 187.

58. Depositions, 155.

59. Incidentally, the law, which made it illegal for anyone other than police officers to carry guns, was criticized by workingmen as discriminating against them. See Frederick Allan Barkey, "The Socialist Party in West Virginia From 1898 to 1920: Study in Working Class Radicalism,” (Ph. D. Diss., University of Pittsburgh, 1971), 188-89.

60. Wheeling Intelligencer, Aug. 30, 1909, Depositions.

61. Wheeling Intelligencer, July 17, 22, August 2, 1909, court order reprinted; also see Amalgamated Journal, July 29, 1909.

62. David T. Javersak, "The Ohio Valley Trades and Labor Assembly: The Formative Years, 1882-1915” (Ph. D. Diss., West Virginia University, 1977), 162.

63. Javersak, 161-65, quote on 165; Barkey 188-89.

64. Amalgamated Journal, August 5, 1909.

65. Wheeling Intelligencer, July 28, 1909.

66. Wheeling Intelligencer April 11,1910.

67. Glasscock to I. V. Barton, July 12, 1909, Glasscock Papers, Box 5, Folder 1.

68. Barton to Glasscock, July 15, 1909, Glasscock Papers, Box 5, Folder 2.

69. Wheeling Intelligencer, July 30, 1909.

70. Amalgamated Journal, August 12, 1909.

71. Iron Trade Review, July 22, 1909; Wheeling Intelligencer, July 16, 1909.

72. Wheeling Intelligencer, July 19, 1901; Amalgamated Journal, July 22, 1909. 
73. Wheeling Intelligencer July 15, 1909.

74. Wheeling Intelligencer July 19, 1909.

75. Wheeling Intelligencer, July 20, 1909.

76. Wheeling Intelligencer, July 15, 16, 1909.

77. Charles Lawyer to Frank Morrison, August 8, 1909, AFL-AA.

78. I. V. Barton to W. E. Glasscock, September 10, 1909, Glasscock papers, Box 5, last folder.

79. Brody, Steelworkers, 127.

80. Gompers to Morrison, June 18, 1909, AFL-AA; also Morrison to Executive Council, AFL, August 9, 1909, John Mitchell Papers, 1885-1919, Reel 16.

81. PJ McArdle \& John Williams to All members of Organized Labor, July 27, 1909, AFL-AA.

82. Amalgamated Journal, August 5, 1909.

83. Quoted in Brody, Steelworkers, 72.

84. Amalgamated Journal, July 29, 1909; Wheeling Intelligencer, July 27, 1909.

85. Wheeling Intelligencer, July 28, 29, 30, 1909; Amalgamated Journal, August 12, 1909; see also Brody, Steelworkers, 122.

86. Charles Lawyer to Frank Morrison, August 9, 1909; P.J. McArdle to Frank Morrsion, August 7, 1909, John Mitchell Papers, 1885-1919, Reel 16.

87. John B. Lennon to Frank Morrison, August 12, 1909, John Mitchell Papers, 18851919, Reel 16.

88. See AFL-AA, minutes, October 3, 1909.

89. “ATTENTION! IRON AND STEEL WORKERS,” AFL-AA; Amalgamated Journal, October 7, 1909.

90. AFL, Proceedings (1909), 123; Wheeling Intelligencer, November 11, 1909; Amalgamated Journal, November 18, 1909.

91. AFL, Proceedings (1909), 184; Wheeling Intelligencer, November 12, 1909.

92. AFL, Proceedings (1909), 227, 335.

93. AFL, Proceedings (1909), 317; also Fitch, 135-36.

94. Wheeling Intelligencer, December 13, 1909.

95. Wheeling Intelligencer, December 13, 1909.

96. Wheeling Intelligencer, December 14, 1909.

97. Amalgamated Journal, December 16, 1909 ; Wheeling Intelligencer, Dec 15, 1909; Wheeling Majority, Dec. 16, 30, 1909. 
98. Wheeling Intelligencer, December 16, 1909.

99. Wheeling Intelligencer, December 20,1909.

100. Wheeling Intelligencer, December 16, 1909.

101. Brody, Steelworkers, 113-14.

102. Wheeling Intelligencer, December 18, 1909.

103. Brody, Steelworkers, 114.

104. Wheeling Intelligencer, July 15, 1909.

105. HB Wessel to Samuel Gompers, April 12, 1911, AFL Convention File (1909), Reel 25.

106. For an example see "Wheeling Business Men Banquet at 'The Oaks," Wheeling Intelligencer, January 20, 1910.

107. Wheeling Intelligencer, August 17, 1909.

108. "Wheeling's Civic Advance," The American City, August 8, 1911, 57-63.

109. Minutes, OVTLA, March 26, 1911, 4:152, quoted in Barkey, 78.

110. Wheeling Majority, May 11, 1911.

111. Amalgamated Journal, December 9, 1909.

112. Wheeling Intelligencer, December 10, 1909.

113. Amalgamated Journal, December 9, 1909.

114. Amalgamated Journal, December 9, 1909.

115. Amalgamated Journal, December 16, 1909; For more on the December militia incident in Aetnaville see Wheeling Intelligencer, December 1-9, 1909.

116. Wheeling Majority, December 16, 1909.

117. Wheeling Majority, January 27, 1910.

118. Wheeling Intelligencer, January 21, 1910.

119. Wheeling Intelligencer, January 22, 1910.

120. Wheeling Intelligencer, May 4, 1910.

121. Wheeling Intelligencer, May 7, 1910.

122. Wheeling Intelligencer, May 14, 1910.

123. Gompers to Organized Labor of America, January 1, 1910, AFL-AA.

124. Wheeling Majority, January 6, 1910.

125. Wheeling Majority January 20, 1910.

126. Wheeling Majority, January 13, 1910. 
127. Foner, 4:303.

128. McArdle letters quoted in "ASSITANCE IN THE WAY OF ORGANIZING MEN (?) ... PROMISED ON BEHALF OF THE IRON, STEEL, \& TIN PLATE WORKERS,” in AFL-AA.

129. Wheeling Intelligencer, February 15, 1910.

130. Amalgamated Journal, February 17, 1910.

131. Wheeling Intelligencer, February 24, 1910.

132. Wheeling Intelligencer, February 17, 1910.

133. Wheeling Intelligencer, February 26, 1910.

134. Wheeling Intelligencer, see especially March 1, 10, 15, 16, and 17, 1910.

135. Amalgamated Journal, March 17, 1910.

136. Amalgamated Journal, March 24, 1910.

137. Amalgamated Journal, March 24, 1910.

138. Amalgamated Journal, April 7, 1910.

139. Amalgamated Journal, March 24, 1910.

140. Iron Age, April 14, 1910.

141. Wheeling Intelligencer, April 22, 1910.

142. McArdle to Frank Morrison, April 26, 1910, AFL-AA.

143. Wheeling Majority, August 11, 1910.

144. Robinson, Amalgamated Association, 26, 26n.

145. John Williams to Frank Morrison, Aug 25, 1910, AFL-AA.

146. McArdle and Williams to "Sir and Brother," August 24, 1910, AFL-AA; John B. Moore, "Collective Bargaining in the Iron and Steel Industry, 1876-1910," (M. A. Thesis.

University of Missouri, 1939), 132.

147. Brody, Steelworkers, 85.

148. Wheeling Majority, September 8, 1910.

149. Wheeling Intelligencer, August 25, 1910.

150. Brody, Steelworkers, 73.

151. Wheeling Majority, September, 22, 1910.

152. Wheeling Majority, September 22, 1910.

\section{Chapter Four: Trying to Change the Union; Too Little, Too Late}

1. Philip Foner, History of the Labor Movement in the United States, 4:281. 
2. David Brody, Steelworkers in America: The Non-Union Era (New York: Harper \& Row, 1969), 60, 73.

3. Jesse S. Robinson, The Amalgamated Association of Iron, Steel, and Tin Workers, (Johns Hopkins University Studies in Historical and Political Science, Series XXXVIII, No. 2, Baltimore, 1920), 19.

4. John Fitch, The Steel Workers (Pittsburgh: Russell Sage Foundation, 1910), 97.

5. Robinson, Amalgamated Association, 43.

6. Robinson, Amalgamated Association, 10; also see Fitch, 81-86.

7. Paul Krause, Battle for Homestead, 1880-1892: Politics, Culture, and Steel, (Pittsburgh and London: University of Pittsburgh Press, 1992), 109.

8. Bruce Laurie, Artisans Into Workers: Labor in Nineteenth Century America, second ed. (New York: Noonday Press, 1991), 35-36.

9. David Montgomery, The Fall of the House of Labor: The Workplace, the State, and American Labor Activism, 1865-1925 (Cambridge: Cambridge University Press, 1987), 9-22. This is probably the best description of the ironworkers" "code," which governed their behavior toward their employers as well as their fellow workers.

10. James J. Davis, The Iron Puddler: My Life in the Rolling Mills and What Came of It, (Bobbs-Merrill Company: Indianapolis, 1922) 30-31.

11. For example, it was predicted that the TPWIPA would fail because of their lack of trade union experience.

12. Robinson, Amalgamated Association, 23-24.

13. Fitch, 104.

14. Brody, Steelworkers, 60, is the best example.

15. Constitutions of the Amalgamated Association, 1876-1889.

16. Laurie, 142.

17. Fitch, 111-115; Elizabeth and Kenneth Fones-Wolf, “The War at Mingo Junction: The Autonomous Workman and the Decline of the Knights of Labor," Ohio History 92 (1983): 37-51.

18. Robinson, Amalgamated Association, 50n.

19. Laurie, 142, 174.

20. Robinson, Amalgamated Association, 43.

21. Robinson, Amalgamated Association, 39, 50.

22. Brody, Steelworkers, 125-126.

23. Fitch, 97-98.

24. Brody, Steelworkers; see Robinson for different interpretation. 
25. Robinson.

26. Robinson, Amalgamated Association, 54; Michael Santos, "Between Hegemony and Autonomy," 35 Labor History (Summer 1994), 403-405.

27. Santos, "Between Hegemony and Autonomy," 410-411.

28. Javersak, 220.

29. J. A. Conkel to Samuel Gompers, August 27, 1908, AFL-AA.

30. John Williams to Frank Morrison, September 4, 1908, AFL-AA.

31. Gompers to John Williams, June 10, 1907, AFL-AA. L. Lewis quoted in that letter also.

32. Amalgamated Journal, January 28, 1909.

33. Amalgamated Journal, February 11, 1909.

34. Amalgamated Journal, February 18, 1909.

35. Amalgamated Journal, March 25, 1909.

36. See letters from Newport, KY, Amalgamated Journal, February 25, 1909; "More Trade Union Spirit and Less Fealty to 'Isms' Needed," letter from Steubenville, OH, Amalgamated Journal, March 18, 1909.

37. National Labor Tribune, July 8, 1909.

38. Amalgamated Journal, June 17, 1909.

39. Robinson, 35-37.

40. Robinson, 55.

41. Robinson, 36n.

42. Brody, Steelworkers, 146.

43. Foner, 4:198.

44. Gompers, Seventy Years of Life and Labor: An Autobiography (New York: Dutton, 1925), 68.

45. Gompers, 68-71.

46. Fitch, 91.

47. Gompers to Morrison, June 18, 1909, AFL-AA; Morrison to Executive Council, AFL, Aug. 9, 1909, John Mitchell Papers, 1885-1919, Reel 16; American Federationist (September 1901); J. E. George, “The Coal Miners' Strike of 1897," 12 Quarterly Journal of Economics, (January, 1898): 186-208.

48. Wheeling Intelligencer, March 23, 1910.

49. Gompers, 155.

50. McArdle to Gompers, June 23, 1910, AFL-AA. 
51. American Federationist 10 (March, 1913), 214-15.

52. Fitch, 349.

53. Wheeling Majority, August 15, 1912.

54. American Federationist 10 (March, 1913), 214-16.

55. Brody \& Fitch - line of promotions.

56. J. D. Pierce to Frank Morrison, October 20, 1913, AFL-AA.

57. JD Pierce to Frank Morrison, May 31, 1913, AFL-AA.

58. Wheeling Majority, February 16, 1911.

59. HB Wessel to Samuel Gompers, April 12, 1911, AFL Convention File, 1909. Reel 25.

60. John L. Lewis to Frank Morrison, May 11, 1914, AFL-AA.

61. Melvyn Dubofsky, Industrialism and the American Worker, 1865-1920, 2nd ed. (Arlington Heights, IL: Harlan Davidson, 1985), 96.

62. Amalgamated Journal, August 12, 1909.

63. Foner, 3:192.

64. Amalgamated Journal, December 2, 1909.

65. Eugene Debs, Writings and Speeches of Eugene V. Debs, (Hermitage Press: New York, 1948), 219-20.

66. Quoted in The Iron Age, March 3, 1910.

67. Milton Derber, "Industrial Democracy," Labor History (Fall 1966): 269.

68. National Labor Tribune, July 22, 1909.

69. Wheeling Intelligencer, March 14, 1910.

70. Wheeling Majority, November 10, 1910.

71. Wheeling Majority, October 19, 1911.

72. Derber, 268; Dubofsky, 103-6, 110.

73. Foner, 4:300.

74. Foner, 4:300.

75. Fitch, 237-8.

76. Foner, 4:300.

77. PJ McArdle to Frank Morrison, Oct 15, 1909 quoted in Foner, 4:302.

78. National Labor Tribune, July 22, 1904.

79. Wheeling Intelligencer, April 9, 1910. 
80. National Labor Tribune, August 12, 1909.

81. Wheeling Intelligencer, November 1, 1909

82. Wheeling Intelligencer, December 24, 1909

83. Wheeling Intelligencer, April 9, 1910.

84. Barkey, 156-58.

85. WS Hunt to Samuel Gompers, June 6, 1913, AFL National and International Union Correspondence and Jurisdictional Dispute Records, Tin Plate Workers' International Protective Association File, Reel 42. Hereafter, cited as AFL-TPW.

86. John L. Lewis to Frank Morrison, June 30, 1913, AFL-AA.

87. John L. Lewis to Frank Morrison, July 11, 1913, AFL-AA.

88. WS Hunt to Morrison, July 8, 1913, AFL-TPW.

89. Morrison to John Williams, July18, 1913, AFL-TPW.

90. Wheeling Majority, May 12, 1910.

91. Wheeling Majority, May 12, 1910.

92. Wheeling Majority, May 26, 1910.

93. Robinson, 45-46.

94. Barkey, 156-58.

95. Barkey, 149.

96. "General Industrial Conditions: Wheeling," (Battle Creek, Mich.) Square Deal, (August, 1914), 79-81.

97. Robinson, 50n.

\section{Epilogue}

1. David Brody, Steelworkers in America: The Non-Union Era (New York: Harper \& Row, 1969), 181, 187. 60.

2. Brody, Labor in Crisis: The Steel Strike of 1919 (Philadelphia: Lippincott, 1965), 53-

3. Brody, Labor in Crisis, 61-65.

4. Brody, Steelworkers, 219.

5. Brody, Labor in Crisis, 113.

6. William Z. Foster, The Great Steel Strike and Its Lessons, 100.

7. Earl Chapin May, Principio to Wheeling, 1715-1945: A Pageant of Iron and Steel (New York: Harper \& Brothers, 1945), 256-57; H. D. Scott, Iron and Steel in Wheeling, (Toledo, OH: Caslon Co., 1929); Brody, Steelworkers, 278. 
8. Scott, 153.

9. John Hennen, unpublished paper on labor relations at Weirton Steel, 1933-1960.

10. Brody, Labor in Crisis, 179-83.

11. Mark McCulloch, "Consolidating Industrial Citizenship: The USWA at War and Peace, 1939-1946", in Forging a Union of Steel: Philip Murray, SOC, and the United Steelworkers, edited by Paul F. Clark, Peter Gottlieb, and Donald Kennedy (Ithaca, NY: ILR Press, 1987), 51. 


\section{Bibliography}

\section{Primary Sources}

\section{Manuscript Collections}

Morgantown, W. V.

West Virginia History and Regional Collection

U. S. Circuit Court, Northern District of West Virginia. Depositions in American Sheet \& Tin Plate Co. v. Frank Bowman, et. al. July 1909

W. E. Glasscock Papers

\section{Published Union Records}

American Federation of Labor. National and International Union Correspondence and Jurisdictional Dispute Records. Amalgamated Association of Iron, Steel, and Tin Workers File. Reel 38-6.

---- $\quad$ Tin Plate Workers' International Protection Association File. Reel 42.

---- Convention File, 1909. Reel 25.

----- Proceedings, 1909 from Reel 6, Labor Union Constitutions and Proceedings, 1836-1974. Glen Rock, NJ: Microfilming Corporation of America, 1974.

Amalgamated Association of Iron, Steel, and Tin Workers. Constitutions from Reel 73, Labor Union Constitutions and Proceedings, 1836-1974. Glen Rock, NJ: Microfilming Corporation of America, 1974. Constitution, By-Laws, and Rules of Order of the National and Subordinate Lodges of the Amalgamated Association of Iron and Steel Workers of the United States, 1876.

----- Constitution, By-Laws, and Rules of Order of the National and Subordinate Lodges of the Amalgamated Association of Iron, Steel and Tin Workers of the United States, 1877.

----- Constitution, By-Laws, and Rules of Order of the National and Subordinate Lodges of the Amalgamated Association of Iron, Steel and Tin Workers of the United States, 1878. 
----- Constitution, By-Laws, and Rules of Order of the National and Subordinate Lodges of the Amalgamated Association of Iron and Steel Workers of the United States, 1879-1880.

----- Revised Constitution and General Laws of the National Amalgamated Association of Iron and Steel Workers of the United States, 1882-1887.

---- Constitution and General Laws of National A. A. I. and S. W. of the United States, 1888-1896.

----- Constitution and General Laws of the National Amalgamated Association of Iron, Steel and Tin Workers of the United States, 1898-1899.

Tin Plate Workers' International Protective Association. Constitution and General Laws of the Tin Plate Workers' International Protective Association of America, 1901 from Reel 75, Labor Union Constitutions and Proceedings, 1836-1974. Glen Rock, NJ: Microfilming Corporation of America, 1974.

----- Proceeding of the Second Annual Convention of the Tin Plate Workers' Protective Association of America, 1900 from Reel 75, Labor Union Constitutions and Proceedings, 1836-1974. Glen Rock, NJ: Microfilming Corporation of America, 1974.

Samuel Gompers Papers. Washington, D. C.: Library of Congress Microfilming, 1967.

John Mitchell Papers, 1885-1919. Glen Rock, NJ: Microfilming Corporation of America, 1974.

\section{Government Documents}

Department of Commerce and Labor. Organization, Investment, Profits, and Position of the United States Steel Corporation. Vol. 1 of Report of the Commissioner of Corporations on the Steel Industry. Washington: Government Printing Office, 1911.

U. S. Census Bureau. Manufacturing. Vol. 10 of Twelfth Census of the United States of America. Washington: Government Printing Office, 1901.

U. S. Congress. Senate. Report on the Conditions of Employment in the Iron and Steel Industry. 62d Cong., ${ }^{\text {st }}$ sess., 1913. Washington: Government Printing Office, 1913.

U. S. Congress. Senate. Investigation of the Strike in the Steel Industries Hearings Before the Committee on Education and Labor. Pursuant to S. Res. 202. $66^{\text {th }}$ Cong., $1^{\text {st }}$ sess., 1919. Washington: Government Printing Office, 1919. 
U. S. Industrial Commission. Reports. Washington: Government Printing Office, 18991901.

\section{Periodicals}

Amalgamated Journal. 1909-1910

Iron Age. 1909-1910 (Iron Trade Review)

National Labor Tribune, 1901, 1904, 1909

Wheeling Intelligencer, May 1909 - September 1910

Wheeling Majority, 1910-1913

\section{Published Contemporary Sources}

\section{Articles}

American Federationist, vol xx, March 1913, 214-215.

Cronemeyer, W. C. “The Development of the Tin-Plate Industry," Western Pennsylvania Historical Magazine 13 (January 1930): 3-54, 123-135.

“General Industrial Conditions: Wheeling," Square Deal (Battle Creek, Mich., Aug. 1914), 79-81

George, J. E. “The Coal Miners' Strike of 1897," Quarterly Journal of Economics 12 (January 1898): 186-208.

Hard, William. "Making Steel and Killing Men," Everybody’s Magazine (November 1907)

Hubbard, W. P. "A Bill to Provide for Mediation, Investigation and Arbitration in Industrial Disputes.” Board of Trade. Wheeling, 1914.

Lawyer, Charles E. "History of the Trade Unions: Tin Plate Workers," American Federationist 10 (September 1903): 841.

“Manufacture of Tin Plate,” Scientific American 87 (November 1, 1902): 290.

The Nation, (August 15, 1901): 124. 
Naylor, Roy Benton. “Wheeling's Civic Advance," The American City (August 8, 1911): 57-63.

Ogden, H. C. "Industrial Democracy, Address Before the Chamber of Commerce, Barnsville, Ohio, December 2, 1920," Pamphlet P5080, WVRHC

Stewart, William R. "Great Industries of the United States: Part IV, Tin Terne Plate," Cosmopolitan 37 (October 1904): 639-50.

\section{Books}

Butler, Elizabeth Beardsley. Women and the Trades: Pittsburgh, 1907-1908. Pittsburgh Survey. Ed. Paul Kellogg, Russell Sage Foundation: New York, 1909, 227-228.

Davis, James J. The Iron Puddler: My Life in the Rolling Mills and What Came of It. Bobbs-Merrill Company: Indianapolis, IN, 1922.

Debs, Eugene. Writings and Speeches of Eugene V. Debs, Hermitage Press: New York, 1948.

Foster, William Z. The Great Steel Strike and Its Lessons, B. W. Huebsch, Inc.: New York, 1920.

Gompers, Samuel. Seventy Years of Life and Labor: An Autobiography. New York: Dutton, 1925.

Roy, Andrew. A History of the Coal Miners of the United States From the Development of the Mines to the Close of the Anthracite Strike of 1902. Columbus, OH: J. L. Trauger, c1902.

\section{Secondary Sources}

Barkey, Frederick Allan. "The Socialist Party in West Virginia from 1898 to 1920: Study in Working Class Radicalism.” Ph. D. Diss., University of Pittsburgh, 1971.

Brody, David. Labor in Crisis. Philadelphia: Lippincott, 1965.

---- Steelworkers in America: The Non-Union Era. New York: Harper \& Row, 1969.

Derber, Milton. "Industrial Democracy," Labor History 7 (Fall 1966).

Dubofsky, Melvyn. Industrialism and the American Worker, 1865-1920. Second Edition. Arlington Heights, IL: Harlan Davidson, Inc., 1985. 
Dunbar, Donald E. The Tin-Plate Industry: A Comparative Study of Its Growth in the United States and In Wales. Houghton Mifflin Company: Boston and New York, 1915.

Fitch, John. The Steel Workers. Pittsburgh Survey. Ed. Paul Kellogg, Russell Sage Foundation: Pittsburgh, 1910.

Foner, Phillip. History of the Labor Movement in the United States. Volume III: The Policies and Practices of the American Federation of Labor, 1900-1909. International Publishers. New York, 1964.

---- $\quad$ History of the Labor Movement in the United States: Volume IV: The Industrial Workers of the World. International Publishers. New York, 1965.

Fones-Wolf, Elizabeth and Kenneth. "The War at Mingo Junction: The Autonomous Workman and the Decline of the Knights of Labor," Ohio History 92 (1983): 3751.

Garraty, John. "The U. S. Steel Corporation versus Labor: The Early Years," Labor History 1 (1960): 3-38.

Green, Marguerite. The National Civic Federation and the American Labor Movement, 1900-1925. Catholic University of America Press: Washington, D. C., 1956.

Gross, James A. “Conflicting Statutory Purposes: Another Look at Fifty Years of NLRD Law Making," Industrial and Labor Relations, 39 (October 1985): 7-18.

Hennen, John. Unpublished paper on Weirton Steel.

Javersak, David T. "The Ohio Valley Trades and Labor Assembly: The Formative Years, 1882-1915." Ph. D. Diss. West Virginia University, 1977.

Krause, Paul. Battle for Homestead, 1990-1892: Politics, Culture, and Steel. Pittsburgh: University of Pittsburgh Press, 1992.

Laurie, Bruce. Artisans Into Workers: Labor in Nineteenth Century America.

Livesay, Harold C. Andrew Carnegie and the Rise of Big Business. Boston: Little, Brown, and Company, 1975.

Loveday, Amos, Jr. The Rise and Decline of the American Cut Nail Industry: A Study of the Interrelationship of Technology, Business Organization, and Management Techniques. Greenwood Press: Westport, CT, 1983. 
May, Ernest Chapin. Principio to Wheeling, 1715-1945: A Pageant of Iron and Steel. New York: Harper \& Brothers, 1945.

McCulloch, Mark. "Consolidating Industrial Citizenship: The USWA at War and Peace, 1939-1946" in Forging a Union of Steel: Philip Murray, SWOC, and the United Steelworkers, edited by Paul F. Clark, Peter Gottlieb, and Donald Kennedy. Ithaca, NY: ILR Press, 1987: 45-86.

Montgomery, David. The Fall of the House of Labor: The Workplace, the State, and American Labor Activism, 1865-1925. New York: Cambridge University Press, 1987.

---- "Industrial democracy or democracy in industry?: the theory and practice of the labor movement, 1870-1925," in Industrial Democracy in America: The Ambiguous Promise, edited by Nelson Lichtenstein and Howell John Harris. Cambridge University Press, 1993.

Moore, John Benjamin. "Collective Bargaining in the Iron and Steel Industry, 18761910.” M. A. Thesis. University of Missouri, 1939.

Mosher, Anne E. "'Something Better Than the Best': Industrial Restructuring, George McMurtry, and the Creation of the Model Industrial Town of Vandergrift, Pennsylvania, 1883-1901," Annals of the Association of American Geographers 85 (1995).

Robinson, Jesse S. The Amalgamated Association of Iron, Steel, and Tin Workers. Johns Hopkins Press: Baltimore, 1920.

Santos, Michael. "Between Hegemony and Autonomy: The Skilled Iron Workers' Search for Identity, 1900-1930," Labor History 35 (Summer 1994): 399-423.

Scott, Henry D. Iron and Steel in Wheeling. Caslon Company: Toledo, OH, 1928.

Temin, Peter. Iron and Steel in Nineteenth-Century America: An Economic Inquiry. MIT Press: Cambridge, Mass., 1964. 